


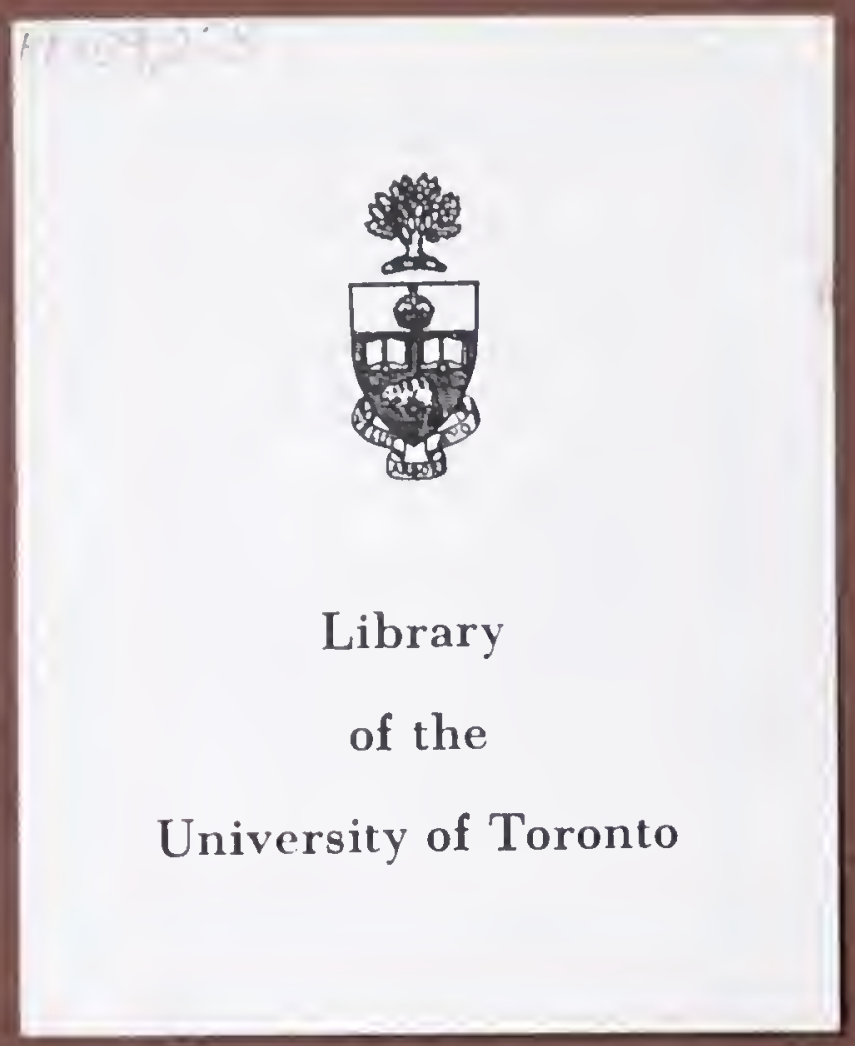



sears.

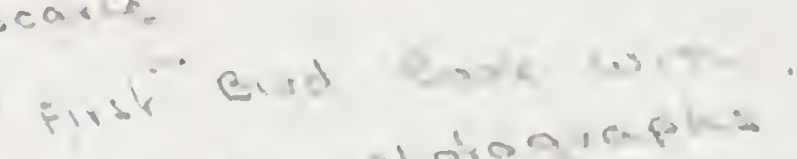

phoiragentes

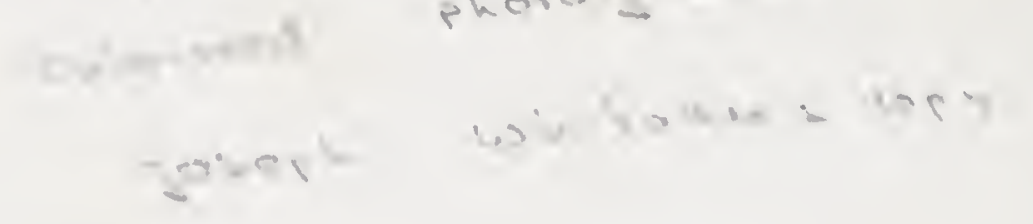

0,21

Freamer 200 ,

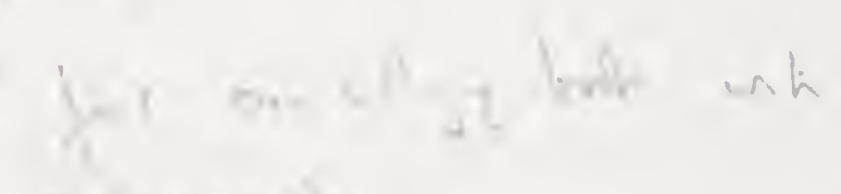


THE BIRDS OF BERKSHIRE

$$
\text { AND }
$$

BUCKINGHAMSHIRE. 
Digitized by the Internet Archive in 2018 with funding from University of Toronto 



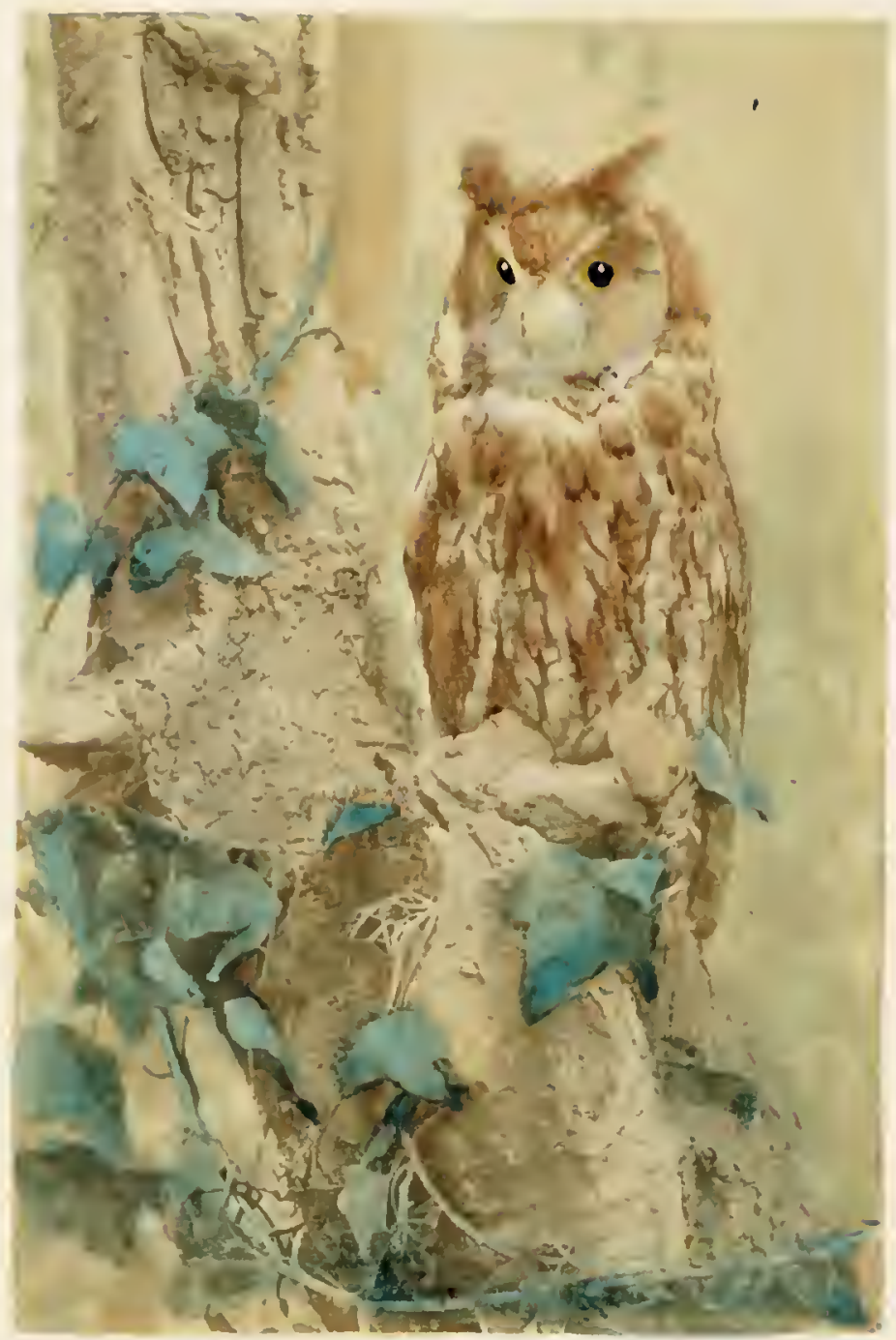

THE LONG-EARED OWL.

Strix otus. 
THE

\section{BIRDS OF BERKSHIRE}

AND

\section{BUCKINGHAMSHIRE:}

A CONTRIBUTION TO THE

NATURAL HISTORY OF THE TWO COUNTIES.

ALEXANDER W. M. CLARK KENNEDY,

"AN ETON BOY,"

MEMEER OT THE HIGH WYCONBE NATURAL HISTURY SOCIETY.

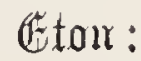

INGALTON AND DRAKE.

agonon:

SIMPKIN, MARSHALL, AND COMPANI.

I 868. 



\section{TO THE READER.}

"Like as the little lark from off its nest, Beside the mossy hill, awakes in glee,

To seek the morning's throne, a merry guest;

So do I seek thy shrine, if that may be,

To win by new attempts another smile from thee."

CIAKF。 



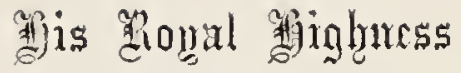

\section{PR I N C E L E O P O L D,}

THIS VOLUME IS RESPECTFULLY

\section{甸edicateo,}

BY HIS HUMBLE AND OBEDIENT SERVANT,

ALEXANDER W. M. CLARK KENNEDY,

IN REMEMPRANCE OF MANY HAPPY HOURS SPENT

WITH HIM AT

WINDSOR CAS'TLE. 



\section{P RE F A C E.}

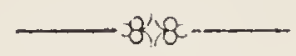

'MAY this magnificent study' (of Ornithology), 'second to none but Theology, daily gain more favour in the eyes of the public; and be the time not far distant when observers shall arise capable of giving greater accuracy and precision to our knowledge of British Birds. While the world endures, be it a thousand years or a million of centuries, the works of God will never be fully comprehended by man; and thus there is delightful occupation in view for all time.'* These are the words of a true Ornithologist, and they seem to point out to us that too much can never be written of the wonderful works of God. Be the writer discoursing on birds, animals, fishes, insects, or any of the numberless works of Nature, he will still have much to learn, many new facts to note down, 
many fresh habits to obscrve; and, lastly, will have an endless source of enjoyment in studying and inquiring into the life-historics of a most intcresting portion of the creation.

A complete Natural History of British Birds can scarcely be written by one man unassisted; but by the inquirics of several into the ornithology of particular districts the task may eventually be accomplished, and, at the same time, more perfectly cxecuted. Surcly if one naturalist would undertake the Birds of this county, another of that, and so on, matcrials for forming a Complete Ornithology of Great Britain would be forthcoming, and ample details would thus be placed in the hands of some compctent person-a future Yarrell-for compiling the work, which would indeed be a boon to all naturalists.

An ardent wish to see the ornithology of each British county represented has prompted me to place these rough notes in the hands of the public, and it has been my endeavour, as far as possible, to follow in the footsteps of the able authors of 'Ornithological Rambles in Sussex,' the 'Birds of 
Middlesex,' and the 'Birds of Norfolk.' I now am pleased to be able to add to the list the 'Birds of Berkshire and Buckinghamshire.' I trust that, ere long, we shall be presented with accounts of the Avi-fauna of many other counties, and that our labour, by being thus divided, will be found more perfectly executed.

Although I have closely adhered to the nomenclature of Yarrell in the following pages, I have availed myself of a method similar to that proposed by the editor of the Zoologist, Mr. Edward Newman, in an appendix to the 'Letters of Rusticus on Natural History,' and one which, I think, if more generally adopted by Ornithologists, would do much towards helping a stranger to form a general idea of the Birds of a particular district.

I have accordingly classed my birds under five heads :-

Residents.

Summer Visitors.

Winter Visitors.

Spring and Autumn Visitors, being the species 
which pay us literally 'a flying visit' during the time of the periodical migrations. And lastly,

Rare and Accidcntal Visitors, which occur only at uncertain intervals.

The two counties whose Avi-fauna I have undertaken to chronicle can boast of no less than 225 species, a number by no means insignificant for an inland county. Doubtless many more rare birds have been obtained of which I have not received notices, but in a future edition I shall hope to add to my list, and shall accordingly be obliged for any notes of the occurrence of rare stragglers in either county which may here have escaped notice.

The following is a summary of the Birds of the two counties according to the arrangement I have adopted :-

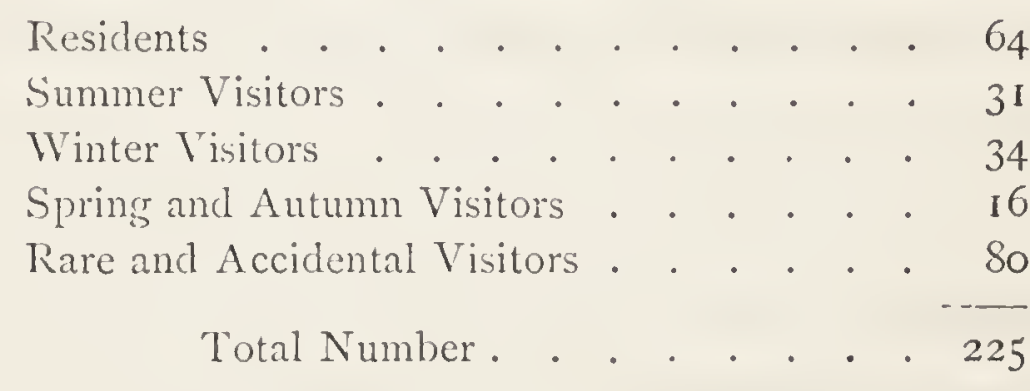

It now only remains for me to return thanks to the many kind friends who have given me their 
help and advice in this my first literary essay; and I will venture to say that in a similar undertaking few have met with more encouragement than has been bestowed on me during the progress of this little work.

To my friend Mr. R. B. Sharpe, of Cookham, I am much indebted for many interesting notes; and to the Rev. Charles Wolley, of Eton, the Rev. H. Harpur Crewe, of Drayton Beauchamp, and Mr. James Britten, of High Wycombe, I am under similar obligations. Mr. J. E. Harting, of Kingsbury, has been most kind in his endeavours to make my work as complete as possible, and I owe him a debt of gratitude for a personal supervision of the following pages as they were passing through the press. The Rev. Bryant Burgess, of Latimer, has forwarded many ornithological notes from the neighbourhood of Chesham; and the Rev. E. D. Stone, of Eton College, has, during the progress of this work, furnished many useful hints. The Rev. F. O. Morris was good enough to write me word that I might make any extracts from his 'British Birds;' and Mr. Gould has kindly informed 
me of several rare captures, and allowed me to take notes from his fincly coloured 'Birds of Great Britain.' To Professor Newton, of Cambridge, I am indebted for much kindly advice and useful information; and Mr. Dalziel Mackenzie, of Henleyon-Thames, also deserves my thanks for a series of notes on some of the rarer birds which have been taken near Fawley, Medmenham, and other places in his immediate neighbourhood. I have received much information from local birdstuffers, but have given credence only to such reports as scemed thoroughly trustworthy.

Lastly, I thank my subscribers for their support, and trust that while they criticise the following pages, they will extend that indulgence which is naturally looked for by an author of sixtecn.

Alexander W. M. Clark Kenneuy.

Eton College, Bucks, March, I 868. 


\section{CONTENTS.}
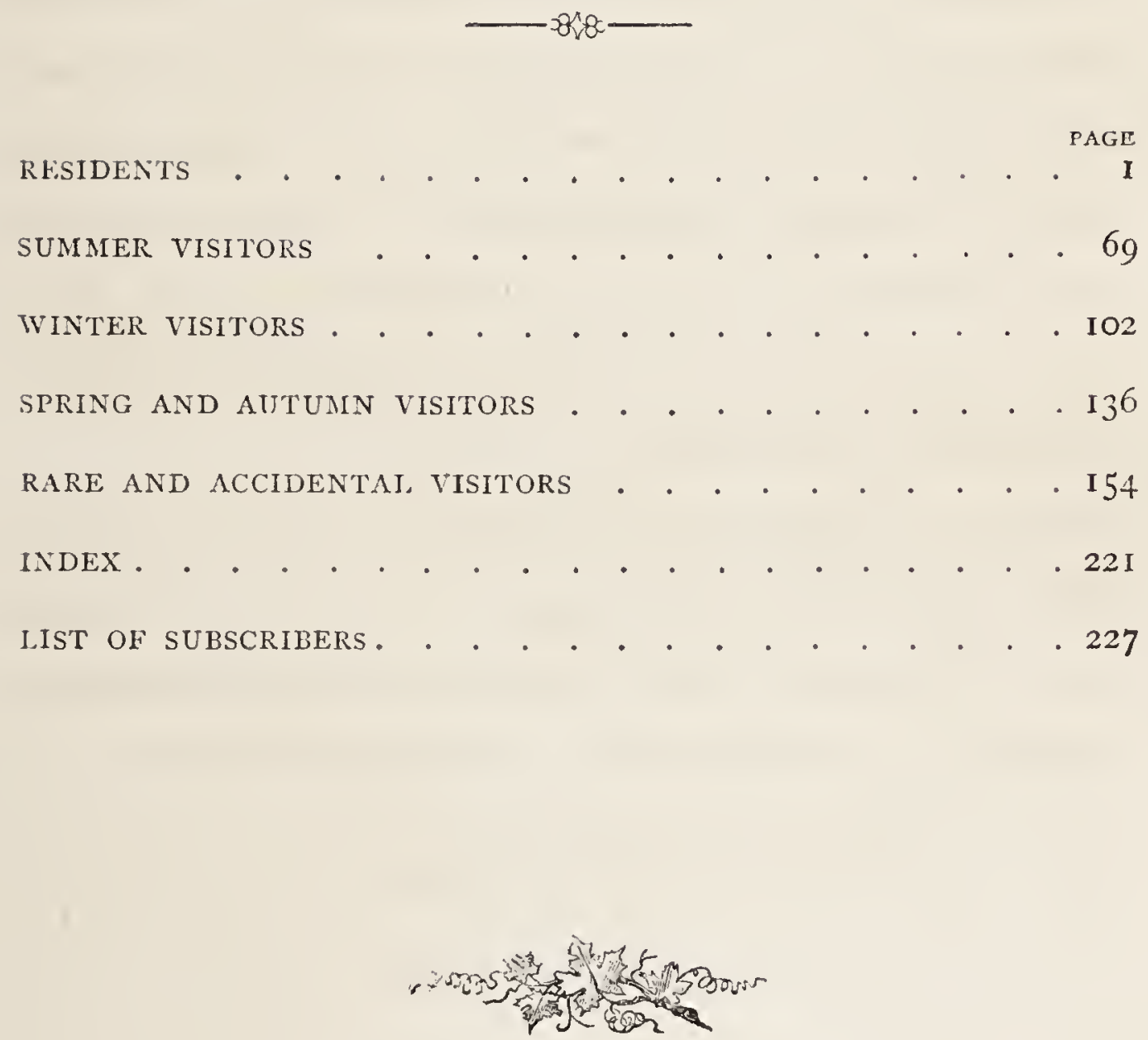



\section{THE BIRDS OF BERKSHIRE AND BUCKINGHAMSHIRE.}

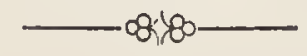

\section{RESIDENTS.}

ORDER I.-RAPTORES.

Family-FaLCONIDE.

Kestrel (Falco Tinnunculus). Local names, Windhover, Hover Hawk. A common species, particularly in the neighbourhood of Eton, Surley, and Windsor. Any one, while taking a stroll in summer, may see one or more of these hawks hovering over the fields in search of its usual food, grasshoppers and mice. I once observed five hunting in the same field. This bird breeds abundantly in both counties, as proved by the number of eggs which are taken in the season, and of these I have seen several curious varieties.

Mr. Sharpe tells me that it is a common bird at Cookham, and that it breeds annually in Cliefden Woods, where he has seen six at one time sailing 
overhead. For two successive years a pair of Kestrels bred in some tall fir-trees at Formosa, and birds of this species have been frequently observed in the grounds of Mr. Burrows at Cookham. Some time since, a male Kestrel was shot in the act of grasping a slowworm, which it held so tightly, that when it arrived at Cookham from Reading its feet still retained their hold, notwithstanding that the victim was alive!

In his account of 'The Birds of Cookham and the Neighbourhood,' Mr. Sharpe states that this hawk feeds chicfly on small birds: I think mice constitute its principal food, although it has occasionally been seen to carry off live sparrows, redpoles, siskins, and gold-finches; and as a proof of its voracity, a London bird-fancier once exhibited a young Kestrel which had been killed and partly devoured by others of its own species.

' I remember well,' says Mr. Sharpe, 'having crept close up to a flock of sparrows, I was about to fire from behind the hedge, when I saw a brown thing jumping about on the ground in the midst of them. I thought at first it was a stoat, but I soon saw it was a Kestrel, and I stood watching it. What surprised me most was, that the sparrows did not fly, but were dodging about like mice on all sides of the hawk, apparently aware that if once on the wing, the hawk would soon overtake thent, whereas on the ground their smaller size and superior agility enabled 
them to elude his grasp. The Kestrel, however, conquered, for I heard a squeak, and then the whirr of the flock as it took flight, and immediately after the hawk flew over my head with a sparrow in its claw. I had never thought of firing till he was out of reach, but I followed the direction he took, and he finally darted out from under a ploughshare, where I found the sparrow with his head eaten off.'

Sparrowhawk (Accipiter Nisus). This also is a common species, but not so numerous as the Kestrel. Many of these hawks are shot annually as vermin, and almost every house one enters with any stuffed birds in it, is certain to contain this hawk among the rest. It breeds abundantly, and so many nests are taken every season, that it is surprising that it contrives to 'increase and multiply' as it does. I have seen many tame Sparrowhawks in Eton and Windsor, and they appear to thrive well in confinement.

By nature the Sparrowhawk is exceedingly bold and impetuous, and many instances are recorded in which one of these birds has been known to fly against a window in pursuit of its prey, killing itself by the force of the shock. The food of this hawk comprises small birds of all descriptions, pheasants, partridges, and grouse, the denizens of the poultry-yard occasionally suffering from its depredations; mice are sometimes, though rarely, found in its crop.

The males separate from the fenales early in winter. 
MARSH HARRIER (Circus cruginosus). Resident throughout the year, but nowhere numerous. It is distributed sparingly in both counties, and is doubtless often confounded with the Hen Harrier. It was formerly more common than it now is; and when there was a greater extent of uncultivated heaths and moorland wastes the Marsh Harrier might frequently have been observed sailing in midair in scarch of prey. A few are still to be scen at various scasons in the neighbourhood of Cliesham; and it remains all the year in some favoured localitics, which are now, alas! 'few and far between,' in the two countics.

The Rev. Bryant Burgess, of Latimer, near Chesham, wrote me word of an immature Marsh Harrier, which was killed some years ago at Risborough.

Hen HARrier (Circus cyanens). Local names, Ringtail, Buszard, Moor Bussard. Resident, but not numerous. A good specimen of this Harrier was preserved by Mr. Hasell, of Bexley Strect, Windsor, who told me that it was trapped by one of the royal kecpers in Windsor Forest in the year I 855 . Another bird of this species-a female-was shot in Windsor Forest in cither I 859 or I 860 , but the exact date has not been recorded. A fine male was shot by a carpenter named Skclton, of Eton, in the ycar i 857. It was resting upon an clm-tree when he shot it, near the mathematical schools of Eton College. I saw the bird in the possession of Mr. Ferryman, of 
Datchet, who had preserved it. He informed me that it was the only bird of this species he ever saw in either of the two counties.

I have been told by Mrs. Hussey, of Brenthurst, Sussex, that some twenty years ago this Harrier used to be a common bird in Buckinghamshire, but it is to be regretted that this species, along with many of our nobler birds of prey, has now almost entirely disappeared from districts where it used formerly to be abundant. This is probably owing to the great increase in the number of gamekeepers, who, of course', kill every hawk they can 'get a sight on,' even the harmless Nightjar being occasionally included as a havk in the 'museums' of such worthies. The Hen Harrier has occurred at Chesham and near Cookham, and it has been observed flying over Langley Park at such a low altitude as to enable the beholder to ascertain the species.

\section{Family-STRIGIDE.}

LoNG-EARED Owl (Otus vulgaris). Local names, Long-ears, Brown Owl, Homed Owl. This is a tolerably common species in most parts of the two counties. Although a nocturnal feeder, I have on several occasions put up a Long-eared Owl by day, and have even observed one of these birds flying along the hedge-rows in broad daylight.

Owls of this species are numerous in Windsor 
Forest, where they are often taken or shot as vermin! Vermin, indeed! I will undertake to say that for every rabbit or leveret they take, they destroy twice as many rats, mice, and moles; and this might be proved if each specimen were examined when shot. They are common in Ditton Park, the seat of His Grace the Duke of Buccleuch, and are to be found in Burnham Beeches, where their nests and eggs have been taken. They breed also in Langley Park, in Windsor Forest, near Winkfield, at Fulmer, and in many other wooded localities.

Mr. Ferryman, of Datchet, states that specimens of this bird are sometimes brought to him from that neighbourhood. The last which came under my notice was a large male bird, in fine plumage, which was killed by a keeper in Stoke Park, about the 2oth of September, I867. The following extract is from a letter from Mr. A. Collins, of the 57 th Regiment, dated Manchester, 22nd November, I 867 :-

'From my earliest recollection there have always been some five or six couple of Horned Owls in a small fir plantation on my father's property, Betterton, near Wantage. Probably the retired situation of this wcod-in a hollow of the Downs-had much to do with the owls' making it their head-quarters, their wisdom being proverbial. My ambition, when I was a schoolboy, was to have one of these as a pet, but as the young birds were always fully fledged and strong on the wing by the time I got home for 
the holidays, the difficulty was to catch one alive. However a deus ex machina arose in the shape of our old gamekeeper's son. This worthy, Charles by name, loaded his gun with split peas, which he informed me would stun the bird only, and while it was in that state it would fall an easy prey.

'I thought this rather improbable, but set off with him to the plantation. After a long and hot search, for it was a broiling day in June, we espied an owl perched high up in a fir-tree and gazing down at us with its big yellow eyes. Bang! and down it came, with blood streaming from its head, and apparently as dead as any door-nail. My coadjutor, however, promptly enveloped it in his velveteen coat, and in a few minutes it was hissing and scratching to an alarming extent. We found afterwards that only one pea had struck it, just above the ear. I consigned it to a hen-coop, and for a long time despaired of taming it, but a low diet worked wonders, and eventually it became so tame that it would ride about on my wrist or head I put up two or three perches in an old ivy-covered tree on the lawn, where it would sit very contentedly; at night, for greater safety, it was consigned to an old dog-kennel.

'Alas! my owl was but mortal, and I found him one cold winter's morning a frozen corpse. I had my old favourite's head preserved, and it now hangs over a formidable array of pipes. Sometimes when 
I look at it-like Wordsworth's thrush in Cheapsideit recalls to me the hot still summer day when we effected its capture, and I almost try to sniff the delicious, fir-scented Downs' air; but as these barracks are environed by a large gasometer, a brickfield, and a tan-yard, the ideal soon merges into a very disagreeable reality.'

The Rev. H. H. Crewe tells me that the Rev. D. Jenks, of Little Gaddesden, has a tame bird of this species, taken from the nest in Ashridge Park, where this owl breeds every year.

White Owl (Strixflammea). Local names, Screch Ozul, White Ozul, Chorubim, Barn Ozel, Church Ozul. This pretty owl is a very common species, and breeds abundantly in the two counties. Several pairs frequent the churches in the vicinity of Windsor, and many old barns possess their pair of 'cherubims.' The species is common in Windsor Great Park and Winkfield, in Berkshire, while in Buckinghamshire it is numerous at Ditton Park, near Eton Wick, Chesham, Cookham, Drayton Beauchamp, at Stoke Park, Burnham Beeches, and many other localities. A nest was taken from a tree in Burnham Beeches, in the spring of $\mathrm{I} 865$, with as many as nine eggs.

A pair of these White Owls built in a cavity near the top of the celebrated Herne's Oak, in Windsor Park, the year before it was blown down.

Mr. Atkins, of Eton, once had a tame bird of this 
species, which had been caught when young; it would hop upon his shoulder, sit upon the table while the family were at breakfast, eat from his hand, and had become quite domesticated.

The White Owl is a great benefactor to man, and shame on him who ruthlessly destroys one of these creatures. It is well known that they do infinitely more good than harm, as their prey consists of common mice, shrews, young rats, insects, and occasionally small birds-never aspiring to game, as is supposed. In the spring of $\mathrm{I} 866$, an owl laid two eggs upon some loose hay in a dilapidated old shed, which used to stand by the side of the river Thames near Eton. The old bird was surprised one evening sitting upon her eggs, and permitted herself to be quietly captured by a boy. In this case there were no signs of a nest-the two eggs were merely laid upon the top of the hay.

Mr. A. Collins, to whom I have before referred, told me that a pair of these owls always nested in the hollow fork of an old elm-tree stretching over an arbour at Betterton, Wantage. One spring, on paying them a visit, he found some impudent jackdaws had driven them into the inmost recesses of the branch, and deposited their own eggs in the poor owls' original nest. He immediately smashed the jackdaws' eggs, as a warning, and after that, the birds of wisdom were unmolested, and continued to occupy their old quarters. 
Tawny OWL (Symizm aluco). Local name, Brozun Owl. A numerous species in the wooded districts. The Duke of Buccleuch's gamekeeper states that there are many of these birds in the Ditton woods, where they breed sparingly: of course, like all other members of this unlucky family of birds, they are shot down as vermin. That they do occasionally carry off a leveret or a rabbit I do not deny, but it appears to me that they do much more good than harm.

Tawny Owls are often shot in Windsor Forest, where they breed. If this bird were not so nocturnal in its habits, there is little doubt but that many more would be destroyed. Its loud melancholy hoot is likely to awaken a vague, uncomfortable feeling in the hearer, if he be not accustomed to such sounds; and should he be walking through a churchyard, or some ancient ruin at the time, the note of this

\section{'Ominous and fearful owl of death'*}

cannot fail to be associated with the idea of dark deeds and ghosts.

Some ornithologists have noted that it is the habit of this species, and of the Barn Owl, to feed on fish: I have never known this to be the case, but Mr. Watertont states that some years ago, on a fine evening in the month of

* Shakespeare's Henry VI. Part I. Act iv. Scene 2. + 'Essays on Natural History,'.p. I3. 
July, long before it was dark, as he was standing on the middle of the bridge at Walton Hall, Yorkshire, and timing the owl by his watch as she brought mice into her nest, all on a sudden she dropped perpendicularly into the water. Thinking she had fallen down in an epilepsy, his first thought was to go and fetch the boat; but before he had got to the end of the bridge, he saw the owl rise out of the water with a fish in her claws, and take it to the nest.

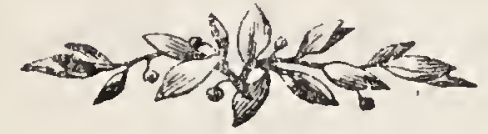


ORDER II.-INSESSORES.

Tribe-Dentirostres. Family-Merulid A:

Missel Thrusin (Turdus viscivorus). Local names, Mistlctoe Thrush, Stormcock. This large Thrush is exceedingly common in both counties, and is one of our earliest breeders. Except in the nestingseason, it is a very wild bird, but at that period it shakes off all fear, and approaches the habitations of man. I have found newly built nests of this bird as early as the end of March, and eggs are frequently taken early in April.

It usually builds its nest high in a tree, frequently in a hollow formed by the junction of two or more branches; I have, however, found a nest in a low hedge about three feet from the ground, in the park near Ditton House. Though not so often observed at other seasons of the year, in spring it may be frequently seen. On the approach of an intruder it will usually set up a loud screeching, and has been known to attack a cat which had ventured too near its nest.

One of the bird's local names, 'Stormcock,' has 
been given it from its habit of singing loudly during stormy weather. The eggs vary much in size and colouring: I possess two with a green ground and no spots; another with an almost pure white ground, and I have seen several perfectly round. Where the nest is built in damp situations, I have always found that the eggs are lighter in ground-colour and markings, and in this I am confirmed by the observations of Mr. Harvie Brown, of Dunipace House, Falkirk.

Song Thrush (Turdus musicus). Local names, Throstle, Mavis. This lovely songster is happily numerous in this district; it is an early builder, for I have known of nests and eggs having been taken in March, and I have found eggs by the Ist of April. I have at different times collected many varieties of the Thrush's egg; two are perfectly round, and several pure blue without any speck or mark, while others have their markings rather red than black. I have always found the pale varieties near water, or in damp localities: in I867 I found a nest in a tree which was flooded by water at its roots; and there were several eggs in it which were quite blue. I once found near Windsor a nest containing eggs, without any mud for a lining, but with merely some dry grass roughly twisted round the inside.

A friend of mine a few years since took a Thrush's nest with four young ones, and shortly afterwards got 
a second nest, also containing young birds : they were all put in the same cage, and one of the older ones belonging to the first brood fed the younger ones every morning and evening regularly. I found a nest of this species on a wooden bench some years ago: they will often build in ivy, jessamine, and other climbing plants; indeed there are few places which they will not in turn select. If the weather be mild they will sing in February, and I once heard a Thrush in full song on a bright day in January.

BLACKBIRd (Turdus Merula).

"The ouzel-cock, so black of hue, With orange-tawny bill"

is universally distributed in England, and Berkshire and Buckinghamshire are alike favoured with the presence of this noted songster. It is, indeed, one of our commonest birds, and a most useful friend to the farmer and gardener. Often have I hidden behind a hedge, and watched a cunning old fellow take up a snail in his bill, the next moment dash it with his whole strength against a stone, and picking up the body of the unfortunate houscholder thus rudely ejected from his habitation, fly off in high spirits to give his young this savoury meal.

I have seen, at various times, many eggs of this bird nearly blue, but none perfectly so. As has been observed in the case of the Thrush, these light-coloured

* Shakespeare's Midsummer Night's Dream, iii. I. 
eggs are, in almost every instance, found in trees or shrubs growing in damp situations.

A good many pied varieties of the Blackbird have occurred at different times, and Mr. Howard, of Burnham, told me that his father once shot a white Blackbird near Burnham. This bird had a perfectly white head and throat, white wings, and several white feathers interspersed on the back and rump: the tail feathers were white and brownish-black.

Mr. G. S. Blane informed me that during the summer of I866 several Blackbirds were seen in the grounds of Wingfield Park, near Windsor, with white feathers in their wings, grey heads, and black and white tails. These were believed to be young birds, and were probably of the same brood: they were very tame, approaching close to the house to be fed.

I sent the following account of a pied variety to the Zoologist for March I867:-

'I saw a curious variety of the common Blackbird, yesterday, at a bird-stuffer's shop in Eton. It was shot, I am informed, at Wingfield Park, which is not far from Windsor, a few days ago (about the 29th of January). On its head it had the feathers on the crown of a pure white colour, the white being continued in little streaks and spots on the left cheek, but not on the right. One of the feathers of the right wing was pure white, and the one next to that was half white, all the others being black. Under the lower mandible of the bill it had some white marls, 
and the whole of the breast of the bird was of a light yellow colour, more like the breast of a Song Thrush. The bill was light brown. This specimen was a female, probably a last year's bird. I saw it in the flesh; it was of the usual size of the Blackbird, and in tolcrably good condition, irides yellow, and eyes of the usual colour.'

This was probably one of the pied brood which frequented Wingficld Park during I 866.

Another pied Blackbird was seen some years since nicar Ditton Park ; and Mr. Drye, a bird-stuffer, of Eton, informed me that about ten years ago he had several nearly white birds of this species. An egg of this bird, hardly larger than that of a house sparrow, was found in a nest with other eggs of the usual size and colour. I have in several instances found this bird's nest built on the ground, and I discovered one in I 863 , in Hertfordshire, which was entirely composed of dry leaves, with a few hairs as a lining.

In I860, a pied Blackbird was killed near the cavalry barracks at Spital. In I862, several black and white birds of this species were obscrved in Ashridge Park, the seat of Earl Brownlow. A male and female of this species, almost pure white in plumage, had been observed frequenting a particular spot in Windsor Forest for the greater part of 1866. One of these was shot by a rat-catcher in December, I 866, and was taken to Mr. Hasell, at Windsor, who ascertained it to be a young male. 
Another, a pied female, was killed about the same time; this bird had been known in Windsor Park to have preserved the same variety of plumage for the three years, I864, I865, and I 866.

Mr. R. B. Sharpe has told me of a variety of the Blackbird, which was shot at Cookham in I864. It was above the ordinary size, and had a ring of white feathers completely encircling its neck. At the base of the bill it had some more white feathers, which contrasted prettily with the jet black plumage. In January, I 868, a pied Blackbird was taken near Clewer.

\section{Family-Sylviade.}

HedGe AcCentor (Accentor modularis). Local names, Hedge Sparroiu, Hedge Warbler, Dunnock. The plain, unobtrusive little Hedge Sparrow is exceedingly common, and breeds abundantly. I once found a nest in a hole in a tree, but the most usual site is in a thick hedge: often it builds in ivycovered trees and walls, generally near the ground. The eggs never vary in colour, but are always pure bright blue. A few years ago I discovered a nest which was snugly placed on the seat of an arbour; and I have heard of another instance in which the parents fed their young in the presence of spectators, when the nest was placed in a similar position.

A pair of Hedge Sparrows, in whose nest a Cuckoo had laid an egg, as if to show that their neat little 
nest was not intended to hold a stranger, forthwith summarily ejected it. Instances in which the Hedge Sparrow has turned out the young Cuckoo, after being hatched, have been often recorded, but I had never previously heard of its throwing out the egg. I once discovered a nest in an old basket, and have been told that a pair built a short time ago in the roof of an out-house. Occasionally a haystack is chosen as a site.

REDBREAST (Erythaca mbcula). The pretty little Robin sings all the year, and is universally beloved -so much so, indeed, that it is thought to be 'bad luck' to kill one of these inoffensive songsters. I have known a country boy to be greatly concerned when he had 'shied' a stone at a bird, and by accident killed a Robin, and I believe there are few who could take pleasure in seeing a Robin fall dead to the ground.

The eccentricity displayed by this bird in choosing out-of-the-way places to build in, has been remarked by many writers. Its attachment to the neighbourhood of man's dwelling is singular, and as if to claim our protection it frequently nests close to our houses. In winter the Robins will come daily to pick up the crumbs outside the windows, and occasionally one is bold enough to enter the room and carry off whatever he can find in the way of food. They are not often so tame as this, except in the severest winters, when their hunger is great, the snow deep upon the ground, and food scarce. 
With regard to the Red-breast building in odd nooks and corners, the following cases have come under my notice. When at Brighton, in April i 867, I was told by Mr. Pratt, of Ship Street, that he knew of a pair of Robins then building their nest in an old Wellington boot, which had been thrown aside by the owner. They had not quite finished the nest when I left Brighton, and I never heard whether they laid any eggs. At Mr. Swaysland's shop on the New Pier, at Brighton, I saw the nest of a Robin, which had been built in a cracked earthenware jar.

During the summer of I866, a person told me that he had found a young Cuckoo in a Robin's nest, in an ivy-covered oak at Charlton, in Kent; when the young monster was about a week old it threw from the nest the poor little Robins, who were killed by their fall to the ground, and the usurper appropriated the whole nest to himself. Such instances, however, have occurred and have been recorded before. I found a nest several years since built in a watering-can, which had been accidentally left in the garden; and about nine years ago, in Surrey, I observed one which was placed between some pieces of matting and a bundle of sticks against a brick wall. I have frequently found the nest in a faggot stack, which is no uncommon site, and have known cases in which a flower-pot has been chosen. I once discovered a nest under an old garden roller; and I have lately been informed that a pair of Robins built their nest in a tattcred hat, which 
was stuck up in a garden near Woolwich, and though the hat used to swing about in the wind the parent birds did not appeai to mind it. A similar instance has come to my knowledge where a nest was built in the coat of a 'scare-crow.' In the summer of I862, while walking along a shady lane near Berkhampstead, I saw a Redbreast fly out of a hole in the bank. On looking for and finding the nest, what was my surprise to discover in it four pure white eggs, which had a lovely pink hue before being blown, but which they have since lost. White varieties are probably not often met with, but Mr. T. E. Gunn, of Norwich, has informed me that they are not uncommon in Norfolk. The nest in question was built in a low bank over a small stream of water, and this is an instance in which the theory of Mr. Harvie Brown may hold good, namely, that all eggs are lighter in colour when laid in a damp situation. This observation has been confirmed by an acquaintance who found a nest with white eggs in a damp ditch near Eton Wick in 1864 .

One cold November night in 1856, a Robin entered a house in Slough and remained until the following spring, when it left, and was never seen again. This bird was exceedingly tame; it roosted upon the top of a bedstead, ate up the crumbs on the table, flew upon the tenant's shoulder, and in fact was as tame as a bird could be.

The food varies considerably: Mëyer gives a long 
catalogue, such as earth-worms, beetles, insects, elderberries, blackberries, earwigs, \&c. ; but he omits the snail, which I have seen Robins eat with apparent relish, after having broken the shell.

Mëyer says that he had a caged Redbreast which used to sing beautifully, which is somewhat unusual: I have seen several caged Redbreasts, none of which ever sang, but were mute and melancholy. I once found a nest with eggs early in the month of March. Mr. Sharpe states that as early as the 7 th of January, I866, a Robin was sitting on five eggs on Mr. Peto's farm, near Cookham.

Stonechat (Saxicola mbicola). The Stonechat is a resident species, but a great addition to its numbers takes place in April, and a similar decrease in August and September: a few only remain with us all the year. It frequents commons and waste lands, and builds its nest on the ground under some slight cover, as a tuft of grass or a small bush. I found a nest in a furze-bush on a common, in I 862, which was quite four feet from the ground, but this is unusual.

It breeds in the neighbourhood of Eton and Windsor, and the eggs are by no means rare. I have noticed very few Stonechats in the colder months but they are occasionally observed in December on Dorney Common: I saw a pair there in January, I 866.

Towards the latter end of March and beginning of April flocks of these birds arrive with Whinchats, 
but many pass onwards and do not remain here to breed. I have occasionally found the nest in the long grass which grows on the banks of the South Western Railway near Datchet. Varieties of this species occur every now and then, which have more or less white intermingled with their plumage.

This bird is observed at Cookham, as Mr. Sharpe writes me word; it is also thinly distributed around Wantage, and a correspondent from Aylesbury remarks that it is not uncommon in that neighbourhood. DARTFORD WARBLER (Mclizophilus Dartfordicnsis). A very local species. It is resident throughout the year with us, but is nowhere numerous.

The only locality* in the two counties in which this species is at all numcrous is a common in the vicinity of Sunninghill, where it is found breeding every summer, and from whence a person in the neighbourhood obtains specimens at all times of the year with which to supply the London birdstuffers. The Dartford Warbler is a bird which is very liable to be overlooked, and I have no doubt but that it occurs on many furze-clad wastes and open commons in both counties, but Sunninghill is the only place where I have hitherto been enabled to authenticate its appearance. Colonel Montagu states of this species that young males begin to sing with

* Since writing the above, I heard of a pair of Dartford Warblers which were shot in the summer of I 866, near Frogmore, where the nest and eggs were at the same time taken. 
the appearance of their first mature feathers, and continue singing all the month of October, sometimes with scarcely any intermission, for several hours together.

Golden CRESTEd Regulus (Regulus cristatus). Local names, Golden Crested Wren, Gold Crest, Kinglet. Generally distributed throughout both counties. This pretty little warbler frequents large woods and fir plantations, and has a pleasing gentle song. A few remain to breed, but the greater number are winter visitors, at which season of the year many arrive in small parties of five or six from the north, apparently unable to endure severe weather.

The nest of this bird is one of the most beautiful of all nests. It is generally found suspended gracefully to the end of a fir-branch, supported by three or more of the over-hanging twigs, and composed of moss, wool, fibres, and lichens, hair or feathers being used for a lining. The egg is the smallest laid by any British bird, but varies in size as well as in shade of colour.

\section{Family-PARIDÆ.}

Great Tit (Parus major). .Local names, Great Titmouse, Ox-cye, Tom-tit, Black-cap. One of our commonest residents, inhabiting hedge-rows, gardens, woods, and lanes. This handsome little bird may at one time be seen ascending an old decayed tree by the road-side with the agility of the creeper in search 
of its insect food, at another grasping a branch with its long hooked claws, and swinging to and fro in mid-air. It is a hardy and courageous bird, and many a peck have I received from its little bill when holding one of them captive in my hand.

Blue Tit (Parus ccrulcus). Local names, Blue Titmousc, Blue-cap, Ton-tit. An extremely common species, impudent, bold, and pugnacious. The nest of the Blue Tit is not an easy one to discover, secreted as it generally is in the hole of a tree or crumbled wall; and if you should happen to find the old bird sitting on her eggs, beware how you introduce your fingers, for she will ruffle up her feathers, hiss in an alarmed manner, and will peck lustily at your hand, which, she knows well enough, is inserted to take herself or her eggs.

As an instance of this bird's quarrelsome and hostile disposition, the following scene, which was witnessed by the Rev. Charles Wolley, of Eton College, may be quoted:-One day, in I860, while taking a walk by Ditton Park, he saw a Blue Tit fly out from a hedge, and attack an unfortunate Hedge Sparrow which was crossing the road. Like a hawk, the Tit flew at the enemy, and succeeded in striking several feathers from the latter's back.

Cole Tit (Parus atcr.) This species, although not so numerous as the Greater, Blue, or Long-tailed Tits, is nevertheless widely dispersed in both counties. It is a lively bird, and seems to be always in 
motion, looking for its food high and low, hither and thither, now scrambling up some old oak, now uttering its harsh note from a birch-tree, and anon flying off again to a distant fir, never tiring, ever happy.

The nest is often placed in the hole of a tree at no great height from the ground, or is sometimes secreted among the decayed roots of an old pollard; but I once found a nest of the Cole Tit in a haystack at Little Gaddesden, near Berkhampstead in Hertfordshire. This is not an usual site.

Marsh Tit (Parus palustris). Local names, Black-cap, Ton-tit. Thinly distributed. This Tit, as appears from its name, is more addicted to low, damp, and uncultivated grounds than any of its congeners. It may be observed frequenting the reedy ditches and banks of the river around Eton and Windsor, and Mr. Wolley has seen it in his garden at Eton.

"The Marsh Tit is immediately distinguished from the Cole Tit by having no white patch on the nape of the neck, nor any white spots on either row of the wing-coverts. ${ }^{\text {, }}$

Long-Tailed Tit (Parus caudatus). Local names, Ragamuffin, Long-tailed Tom-tit, Bottle-tit, and Bumbarrel. This bird is very common, and, like all its congeners, is extremely restless, flitting from branch to branch, from tree to tree. The nest is indeed a beautiful structure, and an irresistible prize to the * Yarrell, vol. i. pp. 374, 375. 
juvenile bird's-nester. Ten or a dozen eggs appear to be the usual complement, but I have known as many as fifteen to be laid.

\section{Family-MotacilLide.}

Pied Wagtail (Motacilla Yarrellii). Local name, Dishwasher. Very common, remaining with us all the year. Small flocks congregate in cold weather, but many individuals disappear in winter, when I have no doubt they move to a warmer climate, as they do not reappear until spring returns. They are, nevertheless, hardy and pugnacious birds; I have seen them fighting when snow covered the ground. The partiality which this bird seems to evince for building in fagot stacks is remarkable, and in May I 860, a nest was taken under the roof of the Formosa boat-house, at Cookham.

Grey Wagtail (Motacilla boamula). A winter visitor to most of the southern counties of England, and a summer one to the more northern. I have seen specimens killed near Windsor, Eton, Surley, Datchet, and other places. It is often observed on the banks of the Thames in winter, but a few have been procured in summer. They are rarely seen in larger numbers than pairs. I was rather surprised to be informed by the Rev. Bryant Burgess, of Latimer, Chesham, that this wagtail annually makes its nest and rears its young on the banks of the little Buclinghamshire river the Chess, where it seems to be 
a summer visitor. On this account I have included it in the list of residents.

\section{Family-ANTHID\&.}

MEAdow Pipit (Anthus pratensis). Local names, Tit-lark, Pipit-lark. One of the commonest of our resident birds, in winter congregating in small flocks and frequenting for the most part the banks of the rivers and the sides of small pools of water. I have found several nests of this bird in the long grass which grows by the side of the railway of the London and South Western Company, between Datchet and Windsor.

Upon one occasion, in the summer of I867, I came unexpectedly upon a Meadow Pipit's nest, containing five eggs, which I appropriated, together with the nest itself. Upon revisiting the spot (which I had marked carefully) about a fortnight afterwards, I was surprised to see another nest and five more eggs in exactly the same position as the former, and I have no doubt that it was built by the same pair of industrious little birds. This time I left the eggs undisturbed, and no doubt they were duly hatched.

Tribe-Conirostres. Family-Alaudid

SKYLARK (Alanda arvonsis). One of the most numerous of our residents, being dispersed everywhere throughout both counties. This bird begins 
to sing early in the year; I have heard a Skylark giving forth its joyous song high above my head before the end of January.

The nest of the Skylark is very carefully concealed. After the young are hatched great flocks congregate, and late in October I have observed immense numbers flying over my head. These birds are annually caught in large quantities by London bird-catchers, who come to our extensive commons for that purpose. Many, too, are shot and trapped, being esteemed for the delicate flavour of their flesh. What cruelty it seems to kcep these birds in close stuffy cages all the year, when they ought to be soaring high in the sky singing their Maker's praise!

Mr. William Harding, of Eton, killed a pure white Skylark at Eton Wick, between the years ISO7 and I8I7: he was unable to tell me the exact date. On the 7 th of January, I 868, a pure white Skylark was shot by Mr. Richard Dover, near Prince's Risborough. Mr. Goodall, of the 59th Regiment, killed another white bird of this species within seven miles of Risborough, in I865. This is recorded by Mr. W. Goodall, in the Ficld of January I8, I868. This curious variety is now in his possession. During the month of June I 867 , I saw eight or nine young Skylarks in a cage, at Eton: some of these were about a fortnight older than the others, and one of the elder birds appeared to feed his smaller brothers and sisters 
every day; but the most curious thing was that he fed them according to a regular routine, always beginning with the same bird and ending with another.

WOOD-LARK (Alauda arborea). This species is a resident, and is found in very small numbers in both counties, but chiefly in the neighbourhood of large woods and rich cultivated ground. Fulmer is one of its favourite resorts.

The principal distinguishing points between this bird and the Skylark are as follows: the former has a shorter tail, and is smaller in its general size, and possesses a very conspicuous streak of light brown over each eye and ear-coverts.

\section{Family-EMBerIzId Æ.}

Common Bunting (Emberiza miliaria). Provincial, Corn Bunting. A common resident, and very generally dispersed. It congregates in large numbers late in the autumn, and is gregarious until the return of spring, when pairing takes place, and the process of oviposition is gone through. This species frequents stubbles and corn-fields (whence its name), and may in early summer be observed delivering its rude song from a thick hedge, usually perched upon the topmost spray.

Blackheaded Bunting (Emberiza schoniculus). Local names, Reed Bunting, Black-cap, Reed Sparrow. Numerous along the sides of marshy ditches and streams; and it is a common bird on the banks of 
the Colne, the Kennet, the Chess, and the Thames. It breeds annually with us; the nest is hidden among long grass or rushes at the river side, and the female lays five or six eggs of a light purple brown colour, streaked and marked with dark brown and black. So curious are these markings that occasionally letters, $\mathrm{X}, \mathrm{C}, \mathrm{A}$, and others, are found more or less distinctly stamped upon the shell.*

Yellow Bunting (Emboriza citrinclla). Provincial, Ycllow Ammor, Ycllow Hammer. By far the most numerous of the Buntings, and one of our commonest residents, frequenting every hedge, field, road-side, orchard, or garden in the two counties. The Yellow Hammer is indeed a pretty bird, and his bright plumage enlivens many a country walk in early spring, when he will pour forth his song-which by the way is not very sweet-from the topmost twig in the yet leafless hedge.

This bird is not an early breeder: the nest is almost invariably placed upon the ground, often on a sloping bank exposed to the sun's rays, and is well concealed. I have found this Bunting nesting within a yard of the rails of the South Western Railway, near Windsor, on a sloping, grassy bank, where Blackheaded Buntings and Meadow Pipits delight to build, apparently undisturbed by the noise and shaking of the continually passing trains. Some birds do not even leave their nest when a train passes within two or three yards of

* This remark applies equally to the eggs of the Yellow Bunting. 
them, in all probability having learnt by experience that the trains will not harm them if they remain still.

\section{Family-FRINGILLIDÆ.}

Chaffinch (Fringilla calebs). Besides its usual name, this bird is locally termed Spink, or Pink. Extremely numerous, and resident with us throughout the year. I have never noticed the separation of the male and female birds in cold weather, in these counties, although I have often looked carefully at flocks, but have generally found them to be composed pretty equally of both sexes : many ornithologists have pointed out that the sexes separate from each other in the winter months.

Many years ago, Mr. Howard, of Burnham, was out shooting small bircis on the estate of the Duke of Sutherland, at Cleveland, when he saw in a hedge a Blue Titmouse and a curious-looking white bird. $\mathrm{He}$ shot them both, and on walking up to the spot, he found that together with the Tit he had killed an albino of the Chaffinch. Mr. Howard had it preserved, and I had the pleasure of seeing it at his house.

This bird has, according to my humble experience, a great partiality for building in laurels. The nest is generally placed high up, but I have on more than one occasion found it almost on the ground. The eggs vary much; I have some nearly white, and several pure blue, of which one was taken from a 
laurel which overhung a stream of water at Frittenden, in Kent: this was in May i 862. Do the materials of which the nest is composed tend to make the eggs of a light colour, or can the colour be affected by the situation of the nest, as for example, damp from the proximity of water? I am inclined to favour the latter view.

Tree Sparrow (Passer montamis). A resident species, but nowhere numerous, and very local. Many suppose that every sparrow which builds in a tree is the Tree Sparrow, but this is not so, as the House Sparrow often resorts to trees for the purpose of nidification. The Tree Sparrow has been shot and seen near Eton, and in Windsor Forest, where a few are supposed to breed. It has also been noticed at Wantage, and Mr. Sharpe writes me word that it has occurred at Cookham and Formosa.

It usually builds its nest in decayed holes in trees, but it occasionally selects other situations. Mr. James Dalton, of Worcester College, Oxford, told Mr. Morris that he had taken the nest of this bird from a Sand Martin's hole, near the town of Buckingham. Specimens have been killed near Datchet, Slough, Newbury, and other places: finally, in summing up, I may observe that although local, it is not rare. The nest and eggs have been occasionally taken in both counties. The following table will be of use in distinguishing this species from the common House Sparrow :- 
Mountain, or Tree Sparrow. House, or Common Sparrow. Head.-Chestnut or chocolatecoloured; a triangular patch of sides of the neck grey-white. black on the cheek.

Bill.--Rather more slender.

General size. - Smaller; the female bird is smaller than the male, measuring about $5 \frac{3}{8}$ inches in length, while the measurement of the male is $5 \frac{5}{8}$ inches.

Legs, toes, and clazes.-Pale brown.

Bill.-Thicker, but of the same colour as the Tree Sparrow.

General size.-Rather larger.

House Sparrow (Passer domesticus). The commonest of all birds, and the most independent, seeming as 'jolly' when the snow lays thick upon the ground, as on a bright summer's morning. A London Sparrow cannot aspire to the same bright colours which adorn the country bird, for the smoke of the metropolis soon turns the brown feathers black, and the white, grey. And after all I do not think a country Sparrow is so very ugly, though he is despised and persecuted by all, and shot unrelentingly by those abominable Sparrow Clubs.

The House Sparrow is very subject to variations in plumage, albinoes or pied varieties being the most usual. In the autumn of I865, a white specimen was killed near Clewer, and was taken for preservation to Mr. Hall, of Windsor; and in December, I867, another white one was often observed feeding with the common species in Clewer village. A white sparrow was shot at Colnbrook, in 1866, and was 
preserved by Mr. Ferryman, of Datchet, who told me of a fourth, which had a purely white head and several wing feathers of the same colour: this last was killed near Datchet a few years ago, but I was unable to ascertain the date. An Eton taxidermist, named Drye, has informed me that he has had scveral yellow, or straw-coloured sparrows brought to him to stuff, which have been taken near Eton and Windsor. His son, Henry Drye, shot a pied House Sparrow in a little garden at Eton, bordering on the Thames, in I 860.

On the 2 Ist of November, I 867 , a House Sparrow was taken to Fisher, one of the Eton bird-stuffers, with a pure white head; it had, however, no other white feathers about it. This bird was shot near Windsor, and belongs to the Rev. M. Steele, who resides in the neighbourhood.

It is said to be the custom with tailors, when they catch an unlucky sparrow, to tic a piece of red cloth round its head and to let it fly, when it is immediately chased and put to death by the other birds.

GreEnfinch (Cocothraustcs chloris). A common resident throughout the year, frequenting orchards, gardens, and hedges, where it does the farmer and gardener good servicc by eating up many noxious insects which infest the trees. It is numerous in every part of the two counties, and is rather a late breeder. I have found quite a colony of these birds nesting in the same hedge, and having some cight 
or ten nests close together. The eggs are generally six in number: Yarrell says, 'from four to six.' The Greenfinch, or Green Grosbeak, as it is often called, from the immense size of the bill, is an easily tamed bird, and is in consequence often kept in confinement.

Upon the 7 th of December, I867, I was shown, in an Eton bird-stuffer's shop, a white, or more properly speaking, yellowish white bird of this species which had just been shot near Surley Hall by a gentleman who had brought it as a curiosity to be stuffed.

HAwFinch (Cocothraustes vulgaris). Local name, Grosbeak. This bird has greatly increased in numbers of late, residing with us all the year, and breeding abundantly in Windsor Forest. The Hawfinch in some seasons is numerous at Latimer, near Chesham, and the Rev. Bryant Burgess says that he has found the nest and eggs there. Young Hawfinches are exceedingly destructive amongst the peas in gardens; one was caught in a garden at Old Windsor, some years ago, by getting its feet entangled in the tendrils of some peas and being unable to extricate them.

The Rev. H. Harpur Crewe, of Drayton Beauchamp, tells nie that he sees a few pairs almost every year in the park at Hartwell House, near Aylesbury, where they breed.

An albino specimen of this bird was taken in the 
latter end of IS64, in the park at Windsor, and was preserved by Mr. Hasell, of Bexley Strect. Mr. R. B. Sharpe writes me word that this bird is met with ncar Cookham in October, sometimes plentifully. A few breed in that neighbourhood every spring, and Mr. Sharpe has seen several young birds which were shot at Formosa.

The Hawfinch is often seen in Stoke and Langley Parks, occasionally in the woods near Newbury and High Wycombe. Yarrell says that it had becn known in his time to breed in the neighbourhood of Windsor; and Mr. Wolley told me that it used to be numerous near Eton when he was a boy. It has a partiality for nesting in whitethorns. Its food consists of the common pea, the seeds of the hornbeam, hawthorn, yew, and other trees, and its strong bill is admirably adapted for breaking the hard shell which many of these possess. Mr. Morris was informed that Hawfinches are common in Stowe Park. It is a common resident at Bradfeld, near Reading; and Mr. Frank Collins states that he has met with this bird at Bettcrton, near Wantage, where one was caught in a gooseberry-net in the autumn of I 867. It occurs also at Clicfden, and Woburn.

GoldFinch (Carduclis clegans). Generally distributed throughout the two counties, where it remains all the year. This pretty bird has greatly decreased in numbers during the last ten years, partly from the rapacity of bird-catchers, and in a great 
measure from the non-abundance of thistles on which it loves to feed, and which are not so plentiful as heretofore. Nevertheless, one may occasionally see the bright-plumaged Goldfinch singing merrily from a spray in a tall hedge in the spring. A few remain to breed, but the species is more numerous in spring and autumn, at which seasons it appears to augment its numbers.

Common Linnet (Linota camabina). A common species, residing with us all the year. This bird has many local names, most of which are derived from its various plumages, as Rose Limnet, Grey Limet, Brown Limet, Lintie, and Red-breasted Limet. The Linnet builds in low bushes, often selecting the furze-bush, but I have known a nest to be placed at the unusual height of six feet from the ground.

Bullfinch (Pymhula migaris). This pretty species is resident all the year, but is not nearly so numerous as was the case a few years ago. I do not mean to say that it is by any means a rare bird, but many localities where it used to be very common, now know it no more. I have often seen Bullfinches in the osier-beds which border the Thames, and their nests, eggs, and young are everywhere indiscriminately taken. Many are annually captured by the London bird-catchers, and this, doubtless, has greatly diminished their numbers.

This bird is occasionally subject to variety. A 
remarkable specimen was shot at Colnbrook in I 865 . It was fawn-coloured, with a little brown upon the head. I saw it at Mr. Ferryman's house in Datchet. In I860, a man named Skinner killed a white Bullfinch near White Waltham, and took it to Windsor, where it was preserved.

\section{Family-STURNIDA.}

Common Starling (Stumus anlgaris). Local names, Stare, Starling. A very plentiful species, and resident all the year. It is an interesting sight to see a large flock of these birds performing their remarkable evolutions in early spring, and to witness the wonderful precision with which they turn, and twist, and wheel, first in this direction, then in that, now towering so as to resemble a spiral column, now lowering themselves, and again looking like a black sheet. These amusing and complicated manœurres may be witnessed by anyone who will take a stroll through Queen Anne's Drive, in Windsor Park, towards the end of February, or early in March.

This species is not unfrequently subject to variety. A Starling with seven white tail feathers was killed near Eton, in I 865 , and is now in the collection of Mr. Drye. Another variety of this bird, a male of a pure cream colour, was shot in a field near Spital, by David Hall, towards the latter end of October I 864 . 
Mr. W. R. Tate has recorded in the Naturalist for I 866, that an albino Starling is in the possession of a carpenter named Craig, at Enfield, which was shot at Slough.

\section{Family-CORVIDA.}

Raven (Corous corax). Though common many years ago, this fine bird is very sparingly dispersed in the counties at the present time.

A few pairs have bred in Windsor Park from time immemorial. They generally select the loftiest trees as a site for their nests. The Rev. C. Wolley informed me that some of these birds bred in the Royal Heronry twenty years ago, and a few still continue to do so. I am not aware of any other locality in either county where they have nested of late years, but stray birds are occasionally seen and killed in various places.

CARRION CROW (Corvus corone). Common in all parts of the two counties where wood abounds, but rare elsewhere. This species keeps in pairs the whole year, and its great powers of vision enable it to discover a carcase from an immense height. The Carrion Crow certainly does not belie its name; nothing comes amiss to it ; pheasant's and partridge's eggs, young rabbits, leverets, dead sheep, snails and grubs, pigeons and mussels, grain, and stinking fish, are all esteemed as the greatest delicacies by this sable robber.

The topmost boughs of some tall hedgerow tree are 
senerally chosen as a fitting site for its nest, which is composed of wool, down, hair, and suchlike materials, supported on a rough platform of twigs and sticks. Macgillivray states that if the male bird be killed, the female soon procures a new mate.

Rook (Corons frugilcgus). This well-known and much-abused bird is numerous everywhere, there being a great number of Rookeries in the two counties, one of the oldest and most interesting of which is in the Eton playing-fields. The first Rook's nest was observed here in the spring of $I_{3} 8$, and after that year the number of nests visibly and steadily increased. Some few years aferwards, as Mr. Wolley informed me, nearly all the trees in the 'fields' were occupied by black denizens; but several pairs of birds deserted certain old trees which they had before nested in, and which were blown down before the close of the year. What wonderful instinct was it that led these birds to seek more secure abodes?

White and pied varieties are occasionally met with. A pied Rook was often observed in the Home Park, Windsor, in the summer of 1845 , and was eventually shot by Mr. James Barfield, at Horton, near Datchet. Worms, grubs, caterpillars, chafers, and other noxious nsects, constitute their chief food.

JACKDAW (Corous monedula). This active and sociable species is very common; and the Round Tower, and many of the belfries and ruined arches of Windsor Castle afford to these noisy Daws excellent 
building accommodation. They generally select chimneys, or holes in trees, for a site; and in some parts of Scotland a popular superstition exists, that if a pair of these birds build their nest in a chimney of the house belonging to an heir, the same spring that the latter comes into possession of that house and his property, no ill-luck can ever befall him.

In the month of May I 842 , a Jackdaw built a nest in the south-east turret of the Eton College belltower: this nest took seventeen days to construct, and was between nine and ten feet in height, being composed of an immense accumulation of twigs and sticks which the industrious birds had collected. The base was firmly supported on one of the stone steps, and curved up the spiral stairs to the height of nearly ten feet, until an exit was obtained by means of a window, and here it was that the top of the structure rested. Unfortunately, no eggs were ever laid in this curious nest, and it was deserted, which was probably owing to the continuous visits of too many eager strangers.

The Rev. C. Wolley told me that a pair of Missel Thrushes, which nested in his garden at Eton one spring, used to attack and drive away some overcurious Jackdaws, who doubtless had an eye to the contents of the former's nest. A tame Jackdaw, belonging to Mr. Ernest Griffin, of the Eagle Tavern, Slough, built a large nest between two beer-barrels, which were placed on a shelf over the bar of the 
public-louse, in the summer of I864; it laid several eggs, but was unable to hatch them. This bird would wander for many miles in the neighbourhood, and being soon well known, was never shot, and always returned safely. It cared only for its master, and used to fly fiercely at any stranger who came in for a glass of beer. It had one very disagreeable trick: having searched for and found several worms and spiders, it would fly on to Mr. Griffin's shoulder and endeavour to force them down his throat-supposing, probably, that he would like them as much as itself.

A short time ago I examined a pied Jackdar, which is now in 'Mr. Hasell's collection, and which was killed by Mr. Cole, Her Majesty's head keeper, in Windsor Park, in 1857.

Magpie (Pica caudata). The handsome and cunning Magpie is but thinly dispersed throughout the two counties, and is not so common as was formerly the case, owing probably to the increase of gamekeepers, who, one and all, seem imbued with a deadly hatred to this bird,

The Magpie is resident throughout the year, and generally remains in pairs, though after the young are hatched ten or more are sometimes seen together. Young birds can be made to talk, and are amusing but very mischievous pets.

JAY (Garmlus glandarius). This handsome bird is common in wooded districts of both counties, in 
which it resides the whole of the year. All gamekeepers I have ever known destroy the Jay whenever it crosses their path, as these birds are supposed to eat eggs and young pheasants. Except with game preservers, the Jay is an universal pet, and can be taught to talk and imitate sounds, such as the mewing of a cat or the barking of a dog.

Mr. G. W. Edgington, surgeon, of Binfield, Berkshire, sent Mr. Yarrell a communication to the effect that he had, at the time of writing, a male Jay which became an excellent mimic before it was twelve months old. The calling of the fowls to their food, and the noises made by the latter, were given in perfection, and this interesting bird was able to mimic the barking of the house-dog exactly.

\section{Tribe-SCANSORES. Family-PICIDA.}

Green Woodpecker (Picus viridis). Local names, Yafflc, Yaffil, Hcru-Hole, Pick-a-trce, and Woodpie. Our commonest Woodpecker. It is one of our handsomest birds, and does an immense deal of good by feeding upon ants and their eggs, and various insects.

I have occasionally observed these birds in Ditton Park, and it is a common species in Windsor Forest, near Cookham, in Langley Park, at Cliefden, and near Wantage ; further north it is not so numcrous. The Rev. H. Harpur Crewe, an excellent ornitho- 
logist, who has favoured me with many notes, wrote me word that he has only once scen it at Drayton Bcauchamp.

This bird's tongue is remarkably suited to its mode of living, and on this subject the rcader would do well to consuit vol. ii. pp. I38, I 39, of Mr. Yarrell's admirable work on British Birds.

Great Spotten WoOdPecter (Picus major). Local names, Black and White or Striped Woodpecker, Pick-a-trec. Not a very numerous species, and chiefly inluabiting parks, forests, and woods, seldom being observed in open and exposed situations. It is fairly common in Ditton and Windsor Parks, and I have seen a pair sitting on a row of posts near some ornamental water in the first-mentioned park, close to each other, and making their peculiar sound. A gentleman mentioned in the Zoologist, a few years back, that he had obscrved one of these birds frequenting his little garden, in the heart of the town of Rcading, for several Sundays running. In Cookham, Taplow, Hedsor, and Cliefden woods, a few may still be seen; also in the Eton College playing-fields it occurs rarely. Burnham Beeches is a favourite resort, and in the vicinity of Chesham it is sometimes observed.

Lesser SpotTed WoOdPECKer (Picus minor). Local names, Lesscr-barred Woodpecker, Little Spottcd Woodpccker, Black-and-whito Woodpccker, and Pick-atrec. Resident throughout the ycar, and fairly 
numerous, although it cannot be called common. I have seen the Lesser Spotted Woodpecker in the Eton College playing-fields, in Windsor Park, and in Ditton Park. Mr. Wolley informs me that he still occasionally sees one in the 'playing-fields,' but that it does not appear to be so numerous there as was formerly the case.

This species is found in the neighbourhood of Reading, Newbury, Maidenhead, and Hungerford. Almost every year examples are obtained at Eton Wick, and occasionally at Winkfield. Several were taken at Dorney, near Brill, some years ago, one of which is now in the collection of the Rev. Bryant Burges, at Latimer. Upon the 24 th of January, I 867 , a specimen with an extremely brilliant red head was shot at Langley, near Stokes; and in I865 and I 866 others occurred in the neighbourhood of Windsor. Lord Clifton, writing in the Zoologist for April I867, records that-'About four Sundays ago I observed a Lesser Spotted Woodpecker on an elm close to my window (at Eton), but the sparrows soon drove it away.' On October 22, I867, an adult male of this species was shot at Stoke Park, Bucks; it was being preserved by Mr. Ferryman, of Datchet, where I saw it, and I remarked that the feathers about the breast and vent were very dirty and worn. Mr. R. B. Sharpe tells me that the breast-feathers of Woodpeckers received from abroad are usually much worn by constant friction, and that these feathers, which 
after a new moult are white, soon become very much discoloured. He has some Woodpcckers from Malacca, whose breasts and tails are completcly clogged with the gum from the trees which they frequented.

In a letter dated November 26, I 867 , the same gentleman says, that owing to the mildness of the early part of November of that year, a pair of little Spotted Woodpeckers began to build in an old poplar on Mrs. De Vitrés grounds at Formosa, Cookham. Mr. Briggs, the head gardener, had fired at a hawfinch unsuccessfully, and was reloading his gun when he heard a tapping above his head, and looking up, he perceived a little Woodpecker hammering at a dead branch with all its might. So intent was the bird on his labours, that the report of the gun had not frightened him, and he worked hard all that day. This was on the IIth, and on the I $3^{\text {th }}$ the hole was visibly progressing. There was just room for the bird to get inside the tree on this day, and the pair worked hard at the interior. Mr. Briggs watched them for some time, and every now and then a little head appeared at the opening and dropped a picce of bark out, and then disappeared, presently reappearing with another piece. So the work went on, till upon the 2 oth the hole was apparently quite finished, but the cold weather which then set in prevented them from continuing their operations.

Mr. Gould* has some interesting notes upon the * 'Birds of Great Britain.' 
occurrence of this species in both counties, which he kindly gave me permission to copy :-

'In Richmond and Windsor Parks, the woods of Taplow and Cliefden and the fine elms of the 'playing-fields' at Eton, it is tolerably numerous.

'To render credit where credit is due, I must first acknowledge my obligations to Mr. Briggs, gardener to Mr. De Vitré, of Formosa, near Cookham in Berkshire, for the assistance he has rendered me in the acquisition of the knowledge I desired. During the last few years several pairs have bred in this beautiful spot, their holes being always made in the upright stems of the broken boughs of the loftiest poplars, at such a height as to be almost inaccessible to any one but a sailor, or an Australian 'black fellow.'

'Aware of my anxiety to become acquainted with every detail connected with the present species, Briggs, at considerable risk both to body and limbs, has mounted several of these mast-like stems, sawn them off, and lowered them to the ground without either the least injury to the eggs or young birds. About the end of April, I86I, a pair commenced excavating in one of these lofty poplars alluded to, at which they laboured assiduously for two or three weeks, bringing the chips one by one to the opening and throwing them out in quick succession; after the work appeared to be completed, a certain time was allowed to elapse for the deposition of the eggs, 
when the dead branch was sawn off a few inches below where the bottom of the excavation was supposed to be. A hole perfectly round and an inch and a half in diameter had been made about six inches from the extremity of the branch, the upper part of which had been blown off by the wind, and was continued downwards for about a foot, gradually increasing in diameter to the bottom, where it terminated in a round cavity about the size of a breakfasê cup. Unfortunately, sufficient time had not been allowed for the deposition of the full complement of eggs, three only having been laid on a few chips of wood almost as fine as sawdust.

'In the year following the same pair of birds drilled a circular hole through the flinty bark of the same branch, and excavated down the stem to a similar depth. On sawing off the branch on the Ioth of June, four young birds nearly ready to fly were found in the cavity. They were very active, frequently ascending to the entrance of the hole and uttering a loud querulous cry. These young birds were sent to the Zoological Society, but did not survive many days. In the spring of I863, the same pair made a hole in another of the Formosa poplars at the height of fifty-five fect, and deposited four egss. These delicate finely-coloured egss were very beautiful, and measured three-quarters of an inch in length by half an inch in breacth.' 


\section{Family-CERTHIAD疗.}

COMmon CReEPER (Certhia familiaris). Resident throughout the year, and generally dispersed over both counties. This little bird is numerous in the Eton College playing-fields, and often on a quiet Sunday morning in spring have I watched one running nimbly up an old tree, so brown in colour as to be hardly distinguishable from the bark itself-now climbing this way, now that, first on this side, then on the opposite, and then off with its pretty jerky flight to search for its insect food on the next tree, always commencing the ascent close to the ground. The Creeper is an early breeder. The nest of this bird is not an easy one to find, built as it is in holes and crevices of trees. The pretty little white eggs, spotted and freckled with brown, principally at the larger end, are laid in a snug nest composed of twigs, wool, feathers, hair, dry leaves, and other soft materials.

Wren (Troglodytes Europeus). Local name, Fimney Wren. The little unobtrusive Wren is abundant everywhere, and is a universal favourite, from the confidence which it reposes in man. It exhibits the same fearlessness as its congener the Redbreast, but is more retiring in its habits, loving to hop unseen among the brushwood, from whence it will fly suddenly out to take a short flight, again to disappear in the hedgerow further on. 
'The Robin and the Wren are God's cock and hen,' says an old rhyme; ${ }^{*}$ and they are certainly more protected by mankind than most small birds. The Wren builds early, and the nest is large for the size of the bird. I have often noticed the similarity of colour between the nest and the surrounding trees or ground. For instance, one which was entirely composed of dry laves was placed immediatcly above a large heap of the same hue: another, placed against a moss-covered stump of a tree, was composed of green materials. When built in a fagotstack it is often brown, to match the colour of the wood.

Varieties of this species are not frequent. In the winter of $1863-64$, a pied wren, almost pure white, was shot near Winkfield, and came into the possession of Mr. Hasell, of Windsor.

Nuthatch (Sitta Europea). Local name, Nutjobber. Remains throughout the year; but, though generally dispersed in both counties, it is not very common. I have often observed these birds on the old elms in the Eton playing-fields, as they ran mouse-like up the stem without making any noise.

The nest of this species is not easy to discover, being generally built in a hole in a tree, and when the hole is too large, the little bird plasters it up with

* Another version is as follows :-

'The Robin Redbreast and the Wren

Are God Almighty's cock and hen.' 
mud until he makes it of the requisite size. Dead leaves, moss, and suchlike substances, are the usual materials with which the nest is lined; but sometimes very different articles are employed for that purpose. One of these bird's nests was taken about ten years ago by an officer of one of the regiments stationed at Windsor, who discovered it carefully hidden in the hole of an old tree in a wood near Eton: this nest was entirely composed of bits of Turkey carpet which the birds had collected from a place not far off where the process of carpet-beating used daily to go on.

One of these birds was caught in a net-trap placed on the ground in a small garden at Eton, in November r867. This specimen was given to me, and I kept it alive in a cage for three weeks, feeding it wholly upon nuts; and the dexterity with which it would crack the hard kernels with a single blow of its strong and formidable bill, was quite surprising. It would fly round and round its prison with great rapidity, and was very active during the night, when its tapping might often be heard; and the person who took care of it for me told me that its tapping occasionally bore a wonderful resemblance to a knock at the door-so much so, indeed, as to deceive him more than once.

In Black Park, near Langley, a curious variety of this bird was shot in I862, and was taken to $\mathrm{Mr}$. Ferryman, of Datchet, where I had an opportunity of 
examining it. The crown of the head was white, as were several feathers of both wings, and some of the back, breast, and tail feathers : the lower parts of the breast and back feathers were slate colour, and the whole appearance of this specimen was very peculiar.

\section{Tribc-Fissirostres. Family-Halcyonid e.}

KingFisher (Alcedo ispida). In my opinion, the species now before us is by far the handsomest of all our indigenous birds. I love to see one of these brightly-coloured Kingfishers dart by with quicklybeating wing, and drop perpendicularly into the placid water, to reappear immediately with a struggling minnow. The victim is soon quicted by a sharp tap against its captor's perch, to which the latter invariably returns, and is then swallowed head foremost. While waiting for its finny prey, the Kingfisher sometimes hovers over the water after the manner of the Kestrel. A fow pairs annually breed along the banks of the Thames, Colne, Chess, and Kennett, as well as in holes in the banks of small streams, and larger pieces of water.

A pair of Kingfishers have, for several successive years, built in the same hole of an old deserted sandpit in the middle of Ditton Woods. In this pit there is very little water, and during a dry season it is perfectly devoid of the least damp; yet here this pair annually breed: but unfortunately the nest has been 
occasionally robbed by some ardent collector, and it is to be feared the birds will eventually desert this locality for some more peaceful abode.

I have always observed that a perceptible decrease in their numbers takes place during the winter months, when a migration most probably ensues, and they again return to their old haunts in spring.

Mr. Frank Collins tells me that one day, in the beginning of November I867, while taking a stroll along the banks of a little stream near Wantage, he saw a remarkably fine Kingfisher lying dead upon the surface of the water. He fished it out, and was surprised to find that the bird had been choked by a fish which it had partly gorged.

The Kingfisher does not often approach the dwellings of man, but the Rev. E. Hale informed me that he has seen this bird in his garden in Eton; and at page 267 of the fourth volume of Loudon's 'Magazine of Natural History,' Mr. James G. Tatem observes that the Kingfisher has been seen frequently flying up and down a small stream which is not 150 yards from the main street of Wycombe.

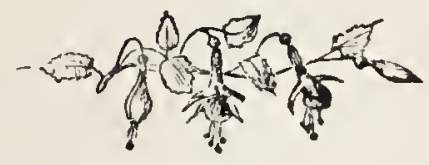




\section{ORDER III.-RASORES.}

Family-Columbidis

Ring Dove (Columba palumbus). Local name, Wood Pigcon, Cushat. A common resident, generally distributed. No doubt everyone is acquainted with this bird under the name of Wood Pigeon; it is distinguishable from the Stock Dove by its larger size, and conspicuous white collar.

In winter these Pigcons congregate in immense flocks, and at that time of the year may be seen feeding upon the beech-mast, of which they are particularly fond. Their food varies considerably; hollyberries, acorns, becch-mast, wortle-berries, clover, ivyberries, charlock-seed, hips and haws, rowans, turniptops, peas, beans, dock-seeds, and various sorts of grain, constitute in turns their 'bill of fare.'

Mr. Hasell, while out for a walk some few ycars ago, saw a weasel attack and fasten on a Wood Pigeon, which rose up in the air to an immense height. Both fell down in about a minute, and he saw the weasel run off apparently unhurt, but the bird was quite dead, although warm. 
Stock Dove (Columba anas). Local name, Wood Pigeon. A resident species, though not so common as the Ring Dove, with which it associates, and is often confounded. Yarrell states that it was termed anas from the vinous claret colour which is visible upon the neck; the name of Stock Dove was bestowed upon it, not because it was supposed to be the origin of our domestic stock, but on account of its partiality for nesting in the decayed stocks of trees, particularly those which have been cut down and become rough and bushy at the top, commonly called pollards.

This bird breeds in many suitable localities in both counties, and is to be seen in flocks towards the end of November and through the winter months, when it frequents the same open ground, and subsists on the same food, as its congener the Wood Pigeon. The nests are sometimes found in Windsor Park, built in decayed stems of old trees.

The Rev. H. H. Crewe informed me that large flocks of this species visit the neighbourhood of Drayton Beauchamp every winter to feed upon the beechmast, to which they seem very partial. I have seen great numbers in Ashridge Park, where I have on several occasions taken the nest: one of these was placed in a small plantation near the Park, not far from the ground in an ivy-covered thorn-treea very unusual site. 


\section{Family-PHASIANID E.}

Common Pheasant (Phasianus colchicus). The most numerous of our game birds, and a common resident. Pied varicties often occur, and I have seen several pure white birds in Windsor Forest.

A hen Pheasant was shot, as Mr. Wollcy told me, from the top of a house in Eton by Mr. John Bradshaw, about the year I837. The bird was sitting quietly on a chimney when first observed, and remained there for some time before it was killed. The variety called the Bohemian Pheasant is sometimes shot in Windsor Park.

The chief food of the Pheasant is grain and various seeds; insects and leaves are also sought for, and Selby says they eat with great avidity the root of the bulbous crowfoot (Ranunculus bulbosus). Pheasants are very fond of acorns also, with which their crops are often distended in autumn.

\section{Family-TetraONID X.}

Black Grouse (Tetrao tctrix). In I8I5, Mr. H. M. Thornton, of Chobham, brought two black cocks and three grey hens from Holland which were turned out on Hurtwood Heath, between Dorking and Guildford, in Surrey, and some of the descendants of these birds strayed as far as Finchhampstead, in Berkshire. 
They have bred near Windsor, in different seasons, but are rare near that town. Some were turned down, a few years ago, in Her Majesty's preserves at Windsor, but many have immigrated and are now located on Ascot Heath, Woking Common, Bagshot Heath, and other suitable localities. In October I 867 , a good many brace of these birds were shot in various parts of Berkshire, and in The Field of October 5, I867, it is remarked that they bred freely during the summer of that year, but the great eagerness of sportsmen to bag them has wonderfully thinned out the broods.

The last which came under my notice was one of which the Rev. Bryant Burgess wrote me word, a fine male, which was killed on Hyde Heath, near Chesham, in the spring of I852. This bird is in the collection of Captain Fuller.

Common Partridge (Perdix cinerea). A wellknown bird, and those who have not seen it in its wild state can at all events testify to the delicate flavour of its flesh. It is common throughout the two counties, although Berkshire and Buckinghamshire cannot be deemed such good Partridge counties as many others.

Selby says that this bird varies much in size, according to the situation and the variety of food.

RED-LEGGed PARTRIDGe (Perdix nubra). Although a resident species, the Red-leg, or 'Frenchman' as it is sometimes named, is not abundant. A few pairs 
breed near Virginia Water and Cumberland Lodge, Windsor Park.

In the reign of King Charles II. scveral pairs of these Partridges were turned out in the park, near Windsor, to obtain a stock; and Mr. Yarrell states he had heard of the occurrence of this bird in Bcrkshire since that time, for all the descendants of the old stock are supposed to have perished long ago. My friend Mr. Sharpe told me of one of these birds which was shot, some years ago, in the ncighbourhood of Cockmarsh, by Mr. Henry Hobbs. The Red-legged Partridge has occurred near Chesham, Reading, Cookham, and in various othcr localities which need not here be mentioned. 


\section{ORDER IV.-GRALLATORES.}

$$
\text { Family-CHARADRIIDÆ. }
$$

PeEwit (Vanellus cristatus). Although a resident throughout the year, the Lapwing, or Green Plover, as it is provincially called, greatly augments its numbers in spring and late in the autumn. During November it is common, and between the end of October and the beginning of March immense numbers pass over Windsor in a southerly direction. In severe winters, as that of $1866-67$, these Plovers sometimes allow themselves to be captured by the hand, for the cold appears to paralyse them and weaken their powers of flight. They are exceedingly useful in a garden, where they do good by demolishing worms, slugs, and other insects. The young birds are able to run as soon as they leave the nest, and they run very fast too, frequently lowering their heads to the ground as they go.

Peewits make their nests (if a slight depression in the soil, lined with a few reeds and bents, can be called a nest) in swampy places and fallow lands in various parts of both counties; some few breed in that portion 
of Windsor Park known as Queen Anne's Drive almost every year, and in damp ground by the side of the river their eggs are annually taken.

The name of Lapwing is derived from the slow and heavy manner in which this bird flaps its rounded wings.

\section{Fanily-ARDEIDA.}

Common Heron (Ardea cincrea).* Local names, Hom, Moll Horon, Molly Heron. A resident species, but more common in the autumn months.

The Heronry in Windsor Park is well worth a visit from any naturalist who happens to be staying in the neighbourhood. It is strictly preserved, no birds being allowed to be shot, and no eggs permitted to be taken. The Herons begin breeding early in March, and eggs are often laid before the end of the month. Young birds may be seen by the end of April.

This bird frequents all small rivulets, and the banks of the Chess, Kennett, Colne, and Thames, where one may occasionally, when turning a bend in the river, come upon a small party of them fishing. Herons are shot every winter upon Dorney Common: in $1866-67$ as many as twenty were killed there in the space of a week. There is another small Heronry near Uxbridge; and this species is found all the year at the reservoirs near Drayton Beauchamp. It is numerous at Cookham, and Mr. F. Collins, of Better-

\footnotetext{
* Hernshaw was the old name for Heron.
} 
ton, told me that Herons are not uncommon in the vicinity of Wantage. Mr. Morris states that a Heronry exists at Coley Park; another is near Reading. The Rev. Bryant Burgess has seen as many as ten Herons fishing together in the water at Shardeloes, near Chesham.

\section{Family-RALLIDæ.}

Water RAIL (Rallus aquaticus). Not very plentiful, but specimens have been killed at all times of the year in both counties. This bird is very retiring in its habits, affecting reedy and secluded banks of rivers, wet ditches, fens, and swampy grounds. It resides with us, in Berkshire and Buckinghamshire, during the whole year.

It has been obtained near Newbury, Hungerford, Reading, Cookham, Maidenhead, Chesham, Drayton Beauchamp, Aylesbury, and many other localities.

A few are every year killed on the river near Windsor, and it often occurs at Datchet and Surley Hall, and, in a word, may be found along both banks of the Thames, Colne, Chess, and Kennett. The nest of this bird is a hard one to find, artfully concealed as it is, generally in willow-beds or among thick water plants. A nest has on more than one occasion been taken near Eton, but it is seldom discovered in either county.

A curious variety was shot in Berkshire, and recorded in Loudon's Magazine of Natural History, by 
'A. B.', who, writing on February I6, I832, says :'Recently a specimen of the Water Rail (Rallus aquaticus) was received from Berkshire, every feather of which was of a pure white. The rich coral colour of the beak formed a singular and beautiful contrast to the delicate hue of the plumage. The specimen was sent for preservation to Mr. Leadbeater, to whom I am indebted for the information.'

Mr. Morris records having seen the Water Rail near East Garston.

MoOrhen (Gallinula chloropus). Local name, Water-hen. A common species, frequenting the banks of streams and rivers, ornamental waters, and large ponds.

The Moorhen is very nimble on land, and I have often detected it by the white under-tail feathers bobbing up and down as it walked along at some distance, without which distinction it would appear like a rook or jackdaw at the distance of several hundred yards.

This bird often perches and roosts in trees; I once found a nest in Ditton Park, placed in a tree, three or four feet above the surface of the water.

\section{Family-LobIPEDIDA.}

Common Coot (Fulica atra). Local name, Bald Coot. A common bird on most ponds and lakes in both counties, but it is not so numerous as the 
Moorhen. The Coot resides with us all the year, breeding in retired nooks and corners, where it is not likely to be disturbed. This species breeds every season among the long reeds and water-plants which grow by the side of the ornamental water in Ditton Park; along the banks of the Thames it is occasionally observed, but being such an exceedingly wary bird it conceals itself upon the least alarm, and so is seldom seen. That well-known sportsman Colonel Hawker observes- - If a gentleman wishes to have plenty of wild-fowl on his pond, let him preserve the Coots, and keep no tame Swans. The reason that all wild-fowl seek the company of Coots, is because these birds are such good sentries to give the alarm by day, when the fowl generally sleep.'

The Coot is a capital diver, and flies well : and has even been observed to climb trees with expertness. 


\section{ORDER V.-NATATORES.}

$$
\text { Family-ANATIDE. }
$$

Mute Swan (Cygmus olor). A royal bird is the Swan-and so it has been considered for many years. The Kings of England used to have Swanherds (Magister dcductus cygnorum), to take care that no harm should happen to the Thames Swans, and even a Mute Swan cannot be shot in these days without incurring a heavy penalty.

Eton College has long had the privilege of keeping Swans upon the river Thames. Yarrell says the College 'Swan-mark' (the mark stamped or cut on their bills) represents the armed point and the feathered head of an arrow, and the following representation is taken from a design cut on the door. of one of the inner rooms of the College.

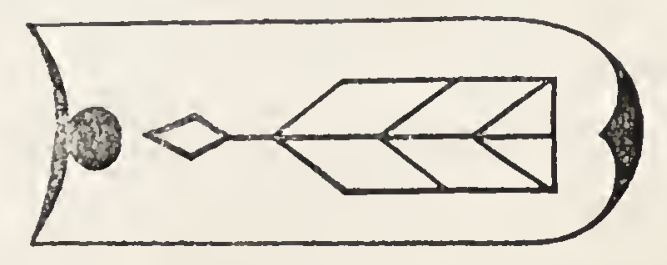

All along the river the Swans may be seen disporting themselves with their young cygnets, which 
the parent bird often carries upon her back. I have many a time laid by the river-side and watched an old Swan lower herself in the water to enable five or six young ones to climb upon her back, and settle themselves comfortably among her warm feathers.

In the summer of I867 a pair of these birds built their nest upon the low river bank nearly opposite the Windsor locks, and had laid half-a-dozen eggs, when the Thames began to rise rapidly. The Swans, probably fearing that their nest would be destroyed, soon collected together a quantity of small boughs and sticks, and were seen by a man standing on the opposite shore to place these upon the nest but under the eggs, raising the latter several inches. The river eventually subsided, and thus by their wonderful instinct these birds saved their nest from destruction, and reared their young in safety.

\section{Family-Colymbid E.}

Great Crested Grebe (Podiceps cristatus). This curious-looking bird has occasionally occurred in both counties, and as it has been observed during the whole year on some of the large reservoirs near Drayton Beauchamp, in Bucks, I feel justified in including it in my list of 'Residents.'

Mr. Morris records that in the year I 808, one was taken near Hungerford, in the month of February; 
and many years ago several were shot on the Thames not far from Windsor. Mr. Wolley informed me that in I862 he saw a large bird, which he fancies must have been a Great Crested Grebe, swimming on the river near Eton. I am glad to be enabled to record an instance of this Grebe's breeding in Buckinghamshire. A nest was found in May I867, which contained three eggs, upon one of the large reservoirs in the vicinity of Drayton Beauchamp, for the knowledge of which I am indebted to the Rev. H. Harpur Crewe, who has favoured me with many ornithological notes. In a letter bearing date the I Sth of December, I 867, the Rev. Charles Wolley observes: 'I have been staying near Tring, and have seen Mr. Crewe. We were at the large rescrvoirs together, and saw one of the Crested Grebes sivimming about. Another was shot there in the autumn. From the evidence of the water-kceper, Mr. Street, which there is not the slightest cause to doubt, there were three nests about the reservoirs last spring, all of which were hatched out. Both young and old birds are still about.'

The Rev. Harpur Crewe wrote me word of one of these birds which he noticed on the reservoir at Marsworth, in Buckinghamshire, during the month of inay i 864.

The nest and eggs of one of the pairs that bred in the spring of $\mathrm{I} 867$ at that piece of water, were taken by Miss Williams, of Tring Park. The Rev. 
Bryant Burgess wrote me word of a fine Crested Grebe which was shot a few years ago at Risborough. LitTle Grebe (Podiceps minor). Local names, Dabchick, Dobchick, Blackchin. This droll little bird, the last on my list of 'Residents,' is common on our ponds, streams, and lakes, and on the river Thames. It is a capital diver, and I have often witnessed its amusing antics from behind an old elm on the river banks in the playing-fields at Eton.

'There is in the parish of Stanford Dingley, Berks, a large and beautiful spring of water, clear as crystal, the source of one of the tributaries of the Thames. I was once bending over the bank of this spring, with a friend, watching the water some five or six feet down, as it issued from a pipe-like orifice and stirred the sand around like the bubbling of a cauldron, when there suddenly passed between us and the subject we were examining, a form so strange that we were at first doubtful to what class of animals we should refer it. In reality, it was a Dabchick, which, alarmed probably by the noise of our conversation, was making for a place of safety: as it passed within two or three feet of our faces, we could distinctly see that it propelled itself by its wings; but it appeared not to have observed us, for it kept on in a direct course for the head of the spring. We searched long in the hope of discovering it again, but failed; and as there were no weeds among which it could possibly hide above water, 
and we could examine the bottom of the spring almost as thoroughly as if it contained air only, we could but conclude that our apparition had taken refuge in a hole under the bank.'*

These little birds are sometimes taken alive in fishing nets; I have seen several that have been so captured in small streams near Windsor. Those who are unacquainted with these small divers in the wild state, would do well to visit the Zoological Gardens in the Regent's Park, where there are always several of this species continually diving for minnows and other small fry which are placed alive for them in their pool.

In Mr. F. R. Buckland's interesting and popular work, 'The Curiosities of Natural History,' it is stated that Mr. Quekett, while fishing one day at Great Marlow, saw one of the birds in question floundering about as if something was wrong with it. Having secured it, the verdict returned after a postmortem examination, was, 'Deceased met his death by being choked by a miller's-thumb in his throat.'

* 'British Birds in their Haunts,' by the Rev. C. A. Johns, pp. 534,535 .

"On cocru brough the birdis hero aै sing eidith boice of angell in ther barmonic, Ehat lousics them thex birdis forthe to brmmg.'

Chaucer. 


\section{SUMMER VISITORS.}

\section{$-18380-$ \\ ORDER I.-R A P T O R ES.}

\section{Family-FALCONID}

HobBy (Falco subbutco). This miniature Peregrine is a regular summer visitor, but never occurs in great numbers. It reaches us about the middle of April and leaves again for warmer climes in October. Whenever one of these birds are seen it is certain to be pursued and, if possible, killed by some ardent gamekeeper; or should it, perchance, be fortunate enough to escape his clutches, some collector will use his best means to procure it for a specimen.

A pair of these Falcons built their nest in a wood not far from Datchet in the summer of I86I. Although the old birds escaped molestation, four young ones were shot, at Thorney, almost as soon as they had learnt to fly. I saw two of these at Datchet, in the collection of Mr. Ferryman, to whom they had been presented. 
Mr. R. B. Sharpe told me of a fine male of this species which was lilled at Cliefden in 1860 , and which is now in the collection of Mrs. De Vitré, at Formosa; and he has occasionally observed one sailing over the woods in the neighbourhood of Cookham. The same gentleman records the following striking instance of this bird's courage, which came under the notice of Mr. Briggs, the head gardener at Formosa :-

This accurate observer of the habits of the feathered tribe had discovered a nest of this species in a plantation at Billing Bare, which is some ten miles from Cookham. He was merely waiting till the young Falcons were fully fledged before he took them. One day he climbed up to the nest, and was forthwith saluted with loud outcries from the young birds. The male Hobby, on hearing the screams of the nestlings, sailed over the woods to the spot, and calmly contemplated the scene of action from a considerable altitude. Having completed his survey, as Mr. Briggs was beginning to descend with his captives, the bird shot down from above with great velocity, his strong wings cleaving the air with a loud noise, and dashed within a foot of the intruder's head; being carried up by the impetus of his descent, he remounted into the air as swiftly as he had stooped, and only paused a second before recommencing the attack. This was renewed in quick succession as Mr. Briggs descended, and he was in 
no ordinary fear lest the hawk should dash at his face. He, however, reached torra frma without mishap, and wishing to obtain the old bird, carried the young into a neighbouring field, where he made them recommence their pitiful cries in order to entice the parent to the place. This plan was perfectly successful, and at the second swoop the fatal charge stretched the devoted bird 'lifeless on the sward.' His first descent was so sudden and unexpected that Mr. Briggs had no time to fire, although he stood ready with his gun, but the second swoop was the last the poor Hobby ever made.

Hobbies are occasionally observed soaring above the trees in Langley Park. Late in the spring of I 866, a beautiful male of this species was killed in the woods near Virginia Water, and was brought to Windsor to be preserved. This hawk has also occurred near Chesham. It was a far commoner species thirty years ago, and used to be found in some numbers in all parts of the two counties. 


\section{ORDER II.-INSESSORES.}

Tribc-Dentirostres. Family-Laniade.

RED-BACKED SHRIKE (I anius collurio). Local names, Butcher Bird, Red Shrike. This is a regular summer visitant, arriving generally in some numbers about the last week of April, or if it be a backward spring, it does not reach us until the beginning of May. It is numerous over every part of Berkshire, and Buckinghamshire, and breeds abundantly. Many nests are taken by boys in the woods and hedges round Eton Wick, Surley, Slough, Datchet, and other localities. The nest of this species is large for the size of the bird, and is roughly constructed; I have seen numbers of this bird's nests; they were all rudely built, and had generally a few small bents, hairs, and sometimes some wool, for the lining.

There is an old woman named Lipscombe who has for many years sold eggs, taken in the neighbourhood of Eton and Windsor, to the Eton boys; this woman receives about ten eggs of the Red-backed Shrike, on an average, perdiem. A friend of mine has 
informed me that he discovered some years ago the remains of a Stonechat impaled upon a thorn-tree by a Shrike of this species. This gentleman is certain that the bird had been 'butchered' by Lanius collurio and not by L. excubitor, as he shot one of the Red-backs, which was disporting upon the tree, and, upon dissection, it proved to have been eating part of the Stonechat. Mr. Hewitson says: 'Seeing a Red-backed Shrike busy in a hedge, I found, upon approaching it, a small bird, upon which it had been operating, firmly fixed upon a blunt thorn; its head was torn off and its body entirely plucked.' It is said by some ornithologists that Lanius collurio does not 'spike' his prey; but the above facts prove the contrary, though perhaps this is not its usual habit.

To enumerate all the localities in which this bird has been obtained would be unnecessary, since it is a common bird in both counties during the summer months.

It usually leaves this neighbourhood in the middle of September, but I have seen it as late as October. A friend lately told me that he believed the last of our migratory birds to leave this country were: the Red-backed Shrike, the Cuckoo, and the Wryneck: he has observed all these birds as late as the middle of October.

Mr. Gould has taken this bird's nest near West Drayton, in 1858 . 


\section{Family-Muscicapid}

Spotted Flycatcher (Muscicapa grisola). Local name, Bcam Bird. A regular summer visitor to this country; it usually reaches Berkshire and Buckinghamshire about the I5th of May, but sometimes a little later, according to the season. It is numerous in Buckinghamshire, and breeds abundantly, but as the nest is not an easy one to find, no doubt many escape detection.

I have known instances of its building against walls, in low shrubs, and in flower-pots; occasionally the cavity between the branches of a large tree is chosen as a site. I once found a nest in Buckinghamshire between three branches of a large tree; there were several eggs, and the nest was quite damp, and if the eggs had ever been hatched I expect that the young would have met an untimely death by drowning, from the accumulation of rain-water in the cavity; such instances have occurred. I knew of an instance in which the birds built several times over the door of a dwelling-house, after their nest had been once destroyed.

It is amusing to watch this little bird 'hawking' for its prey, which consist mainly of flies, blue-bottles, gnats, small butterflies, and moths. One day, in June I867, while hiding behind a fine old oak-tree in the Eton fields, I witnessed a curious sight:-A large brown butterfly was flying quickly backwards and for- 
wards by the river-side, when a Spotted Flycatcher made a sudden dash at it from a branch above my head; it missed its victim, which was too large for its little mouth to catch easily: the bird continued dashing at the butterfly, missing it, and turning round sharply to renew the attack. Each time the bird missed its intended victim I could hear the bill snap with a sharp 'crack,' although some twenty yards distant. The bird at last gave up the pursuit, and returned to its former perch on the oak-tree, no doubt considerably disappointed.

Its little chirping note is rather pleasing to the ear, but it can scarcely be called a songster. It leaves us at the latter end of September.

\section{Family-Sylviadæ.}

Redstart (Phonicura muticilla). Local names, Red-tail, Fire-tail. This bright-coloured little bird arrives here about the middle of April. I have rarely observed it earlier. It is not one of our commonest birds, yet I cannot call it rare. I have seen many in Burnham Beeches, which woods they frequent in the greatest numbers in May and June. They are occasionally observed in Ditton Park and in Windsor Forest. I have known but few instances of their nesting so far south as this; but Mrs. Lipscombe, the Eton vendor of bird's-eggs, tells me that she generally has a nest every year. This old lady gets most of the eggs of this vicinity, as 
her husband drives round the neighbouring villages two or three times a week during the season, and he collects about three hundred eggs on each journey, exclusive of Thrush's and Blackird's.

Mr. R. B. Sharpe has informed me that the Redstart occurs in the woods around Cookham. It has also been observed in small numbers near Wantage, as I am informed by Mr. R. H. Collins, and is occasionally seen in the neighbourhood of Abingdon.

Winnchat (Saxicole rubetra). No Whinchats remain with us through the winter; the species is migratory, and is first observed in small numbers towards the close of April. It is but sparingly distributed over these counties, and is not so numerous as the Stonechat; but it breeds annually on Dorney Common, and in many other parts of the countics.

Mr. R. B. Sharpe tells me that it is seen near Cookham; it is not rare in the vicinity of Wantage, and is observed in the northern parts of Buckinghamshire: it occurs sparingly near Maidenhead, and is seen in summer at Chesham in small numbers.

WheATEAR (Saxicola Enanthe). Local names, Whitc-tail, White-rump, or Fallow-chat. He who takes a stroll in the meadows in April, may observe a little bird with a white tail spring suddenly up from a stone on which it was sitting, and fly on before him for thirty or forty yards, when it will rest on a gate or on the ground until again approached; it will again rise and accompany him 
still further, flying perhaps in this way for a mile or more. This is the Wheatear, one of the earliest of our summer visitors, generally arriving here about the end of March or beginning of April. In 1866 they were first seen on the 2oth of March, on which day a bird in poor condition was knocked down by a boy with a stone in a field known as the 'Brocas,' near Eton.

Wheatears are extremely numerous here in summer, and a few nests are taken on the commons every year: the district is not wild enough for many to breed; they like dreary wastes and hill sides or moors.

They generally leave us at the latter end of August, although many stay on until the middle of September. They assemble in vast flocks on the southern coasts at the time of their autumnal migration ; and it is generally supposed that they travel by night. In many counties they are taken by means of a horse-hair noose, which is placed in a hole between two clods of earth. Into this hole the unsuspecting bird will fly if any danger is at hand, probably thinking, like the ostrich, that if he cannot see anyone, nobody can see him. This plan is much practised by shepherds on the downs, who sell them for about a penny apiece. For the Wheatear is considered to be as great a delicacy as the Lark.

The eggs are usually pale-blue, but I have taken a nest with pure white eggs, in Sussex. 
Grasshopler WARbler (Salicaria locustella). This shy little warbler is a regular summer visitor, but cannot be called common. It is very retiring in its habits, living among the thickest undergrowth of the woods, but is probably local rather than rare.

A few nests are taken almost every summer in this neighbourhood; although I have never found one in either county myself. It is a difficult nest to find, being secreted among the tangled grass and thick herbagge which usually surround furze and other small bushes. The eggs of this species are white, closcly freckled with pink or reddish-brown, and scarcely ever vary.

It occurs at Wantagc, Chesham, High Wycombc, and Drayton Beauchamp; and in the neighbourhood of Cookham it is not uncommon in June and July. Its note is not unlike the 'chirping' of the Grasshopper, from which circumstance it has derived its name.

SEDGE WARBLER (Salicaria phragmites). Local name, Fan-tail Warbler. In early summer, the osicr-beds on the banks of the Thames, from Staines to Wallingford, resound with the joyful notes of this little visitor, which arrives punctually betwecn the roth and 2oth of April, to cnliven our rivers and lakes with its variable song. I say variable, because it has often been noticed that this species is a regular 'mocking bird'-imitating the note of the Xellow Wagtail, the Skylàrk, and the 'twit- 
twit' of the Swallow in rapid succession: it has been known also to imitate the note of the Starling and the Missel Thrush, as well as the call of the Wryneck. It has been argued that these so-called imitations of the notes of other birds is a part of the usual song of the Sedge Warbler, and not an imitation at all: and this opinion is probably the correct one.

The Sedge Warbler leaves us in the middle of September: I have occasionally seen a few which linger on until the end of the month, and $\mathrm{Mr}$. Yarrell, at page 290 of the first volume of his 'History of British Birds,' relates, that 'on one occasion a single specimen was observed near High Wycombe in Buckinghamshire, in winter,' but gives no date. The Sedge Warbler breeds in tolerable numbers along the banks of the Thames and Colne, and in the reeds and flags which surround many ornamental pieces of water and small streams in different parts of the two counties. The nest is usually placed near the ground, often between the branches of a young osier or willow; sometimes it is built upon the bank, and at others, in the reeds in the middle of a pond or lake. The eggs are generally five or six in number, but in the spring of 1867 , I found a nest containing the unusual number of nine.

Beetles, and various small water insects, constitute the principal food of the Sedge Warbler. 
In Junc, I 867 , I discovered a nest of this species in a low laurel in Windsor Home Park, with two pure white eggs, one with a few brown blotches at the end, otherwise white, and a fourth of the usual type. In I 865 I saw a similar varicty of the Sedge Warbler's cgg, which was found near Windsor, and idcntified. Mr. Crewe says that this bird is very common in his parish of Drayton Beauchamp, near Tring, where it brecds abundantly on the shores of the reservoirs.

ReEd Warbier (Salicaria amadinacea). An exccedingly common bird, arriving in this district in the month of April, and leaving us towards the end of Septcmber.

It is numcrous along the banks of the Thames, Colne, Chess, and Kennet, as well as by the sides of large ponds, and among the reed-beds on the banks of the reservoirs near Drayton Beauchamp. Its plcasing song, too, may be heard from the osiers which are so common by the sides of the sluggish strcams and rivulcts throughout the district.

This Warbler appears to have first been made known as British by the Rev. John Lightfoot, who, in a communication to Sir Joseph Banks, which was read before the Royal Socicty, and printed in their Transactions for the ycar I 785 , described this bird from specimens which he had discovered frequenting the reeds on the banks of the little river Colne from Iver to Harefield Moor, a distance of some five miles. 
Thus Buckinghamshire can claim the discoverer of two British birds, the Reed Warbler and the Lesser Whitethroat.

Of late years I have remarked the partiality which this species evinces for nesting high up in lilac-trees, and generally at some distance from water. I have had some correspondence with Mr. J. E. Harting on this subject, for he has remarked the same thing; but on comparing notes, and examining a good series of eggs, he and Mr. Blyth have come to the conclusion that the species thus found nesting in shrubs at a distance from water, is nevertheless identical with $S$. anmdinaced. It is remarkable that this divergence from the usual habits of the species should have been unnoticed by all previous writers, but since the peculiarity was pointed out by Mr. Harting, his observations have been confirmed by other naturalists.

Nightingale (Philomela huscinia). This, our finest songster, is a regular summer visitor, reaching us about the $25^{\text {th }}$ of April. Males arrive a few days before the females, and directly the former come, many bird-catchers are on the qui vive to capture them, as it is said a male bird will not survive long if taken after the females have arrived and his song has gained him a mate.

The nest is, in most cases, built upon a bank, but in May I867 I discovered one constructed of oakleaves, hair, and wool, placed about two feet from

*Vide 'The Birds of Middlesex,' pp. 45-47. 
the ground in a laurel. I took out, on successive days, four eggs, one by one, and each morning the hen laid a new egg, thus proving she will not easily desert her nest.

BLACKCAP (Cumara atricapilla). This charming Warbler, second only to the Nightingale, is a regular summer visitor, reaching this country in April and leaving in September, although a few in some ycars remain until October. This bird is not so common as many of the other Warblers in either county, although generally dispersed.

The eggs of the Blackcap are subject to much variety, some resemblng those of the Garden Warbler, others those of the Tree Pipit. The nest is generally placed in a low bush or hedge, about three feet from the ground. The male bird occasionally relicves the female during the process of incubation; I have more than once seen a male on the nest, in which position the bird has occasionally been heard to sing. The Blackcap is partial to wooded and enclosed districts, rarely being observed on commons or tracts of waste and open laind.

Garden Warbler (Curmach hortensis). Generally dispersed, but by no means so numerous as either the Blackcap or Common and Lesser Whitethroats.

It reaches these counties towards the end of April, quitting them again in September. As its name implies, it frequents gardens, and is of very retiring 
habits, although its pleasant note may often be heard in a thick wood or among straggling bushes. Insects, berries, peas, and fruit of various kinds constitute its principal food.

Common Whitethroat (Curnuca cinerea). Arrives towards the end of April, from which month until September it is one of the commonest of our Warblers. It frequents hedges and woods; and nettles, brambles, and other low-growing weeds which cover many of our country lanes are much sought by it. Male birds usually reach this country before the females, as is the case with the Nightingale, the Blackcap, and several other of our summer visitors. Its provincial name, Nettle-creeper, is no doubt derived from its partiality to localities in which that plant abounds.

Lesser Whitethroat (Cumma sylviclla). A common summer visitor, but not so numerous as the last-named. This pretty Warbler was first discovered near Bulstrode, in Buckinghamshire, where it was procured by the Rev. Mr. Lightfoot, who sent specimens of the bird, then new to Britain, to Dr. Latham, and this gentleman figured and described it at page I 85 of his 'General Synopsis.'

The lesser Whitethroat reaches the neighbourhood of Eton and Windsor about the end of April, after which time its pleasing song and pretty form may be heard and seen in the tall hedges in which it delights to build. It usually places its nest five or 
six feet from the ground, and I have found the nest in a lilac-bush, which is rather a frequent site. This bird leaves us about the third week in September.

WOOD WarbLer (Sylvia syliticola). Local names, IVood Wren, Yellow Wren. A regular summer immigrant, but never appearing in such numbers as the two following species. It arrives during the last week in April or early in May. The chief food of this little bird consists of insects and their larva. The nest is a difficult one to find, as it is generally artfully concealed under a tuft of grass, or among thick and tangled undergrowth in a wood. 'The hen lays five or six prettily marked eggs, white in ground colour, specked and blotched all over with deep reddish brown and ash colour; often the eggs are so much darkened by these markings that it is not easy to distinguish the ground colouring.

The Wood Warbler leaves us in September.

Willow Warbler (Sylvic trochilus). Local name, Yellow Wren. Arrives about the second week in April, but occasionally before this date its gentle pleasing note may be heard.

In the month of June, 1867 , I found a nest containing eggs in one of the lower branches of a hollytree in Windsor Home Park, which is an unusual position, for this bird generally builds upon the ground.

A pair of Willow Warblers built their nest, early in the spring of I 866 , among some long grass in front 
of a park-keeper's house on the banks of the Thames. The female, while sitting on her eggs, never shewed the least fear when the keeper's children looked in at her, or even put their hands close to the nest; nor did their boisterous laughter and noisy voices alarm the bird at all, though they were accustomed totrample about in the grass within a yard of the nest at all times of the day.

Chiff Chaff (Sylvia hippolais). This small Warbler is the first of the summer visitors to reach us, with the exception of the Wheatear. Its sprightly form may be seen, and its pleasing song heard in the yet leafless hedges, before March is over; small numbers usually arrive about the 2oth of that month.

The nest is generally placed on the ground, but in the summer of 1867 I found one built three or four feet from the ground, among the ivy which grows in clusters over the Albert Bridge, in Windsor Home Park. This species leaves early in October.

\section{Family-Motacillide.}

Ray's Wagtail (Motacilla fava). Provincial names, Yellow Wagtail, Yellow Dish-washer. The Yellow Wagtail was first discovered by John Ray, and Mr. Yarrell named it after him in order to distinguish it from the four species of Yellow Wagtails which are indigenous to Europe.

It reaches us early in April, and departs in Sep- 
tember. A few pairs annually breed by the side of ponds and small streams, but the nest is a hard one to find, being generally well concealed among rushes and long grass.

\section{Family-ANTHIDA.}

Tree Pipit (Anthus arborcus). A common summer visitor, arriving about the beginning of April, and leaving in September. This species is not nearly so numerous as its congener the Meadow Pipit, and, unlike the latter bird, does not remain in Britain all the year.

Early in spring one may hear his cheerful song, the bird itself sitting upon the extremity of the branch of some large tree. The nest is placed on the ground, generally artfully concealed under a patch of grass or a low bush; I have sometimes almost set my foot upon the nest before the old bird attempted to stir.

This Pipit, as well as the other species, is locally known as the Tit-lark.

Tribe-SCansores. Family-PICIDA.

WryneCK (Yunx torquilla). This third division of the Insessores comprises the Scansores, or climbers, a tribe of birds remarkable, as the name implies, for their powers of ascending trees, having their toes arranged in pairs, two before and two behind. 
The bird now before us is a common summer visitor, arriving in April, about the same time as the Cuckon, whence it has gained one of its provincial names, Cuckoo's Mate. Another local name is Peabird, which was probably given it from the fact that about the time of its arrival young peas are springing.

In I 865 , a pair of these birds built their nest in a hole in an apple-tree in an orchard near Burnham. The female was one day captured by a boy while sitting on her eggs, and was brought by him to Eton, and sold to a gentleman who set it at liberty. The boy who had caught it observed the bird on the appletree the next morning, and as he had marked it, it could not have been mistaken. What curious instinct had enabled this bird to find its way back again, after having been carried in the boy's pocket a distance of seven miles?

\section{Family-CuCULID}

Common Cuckoo (Cuculus canomis). Every one is acquainted with the Cuckoo, if not by sight, by its well-known note. 'Have you heard the Cuckoo yet?' is as much a household expression as 'When did you see the first swallow?' It arrives in April: and the mean date of its advent appears to be the Ioth of that month.

I have observed as many as five of these birds on the wing together in Windsor Park, in June and July, when they appear to. be more gregarious than at other 
times. The Cuckoo generally leaves us in the early part of September, though I once saw three in Ditton Park as late as the 2oth of November. For information on certain peculiarities in the life-history of this remarkable bird, I must refer my readers to a capital paper by the Rev. A. C. Smith, in the Zoologist.*

Tribe-Fissirostres. Family-Hirundinide.

Swallow (Hirundo mestica). Perhaps no bird is more anxiously looked for in spring by dwellers in the country than that harbinger of summer, the Swallow.

It arrives in this country about the 12 th of April, but in some seasons a few stragglers may be observed earlier. In I867, upon the Ist of April, a pair of these birds were seen hawking about that part of the Thames which flows through the Eton College playing-fields; and some have arrived in the neighbourhood before the end of March. The following is an extract from a letter from my cousin Mr. John Kennedy, dated 2 Ist August, I867, written at Rosetta, near Launceston, Tasmania:- 'We are now in the beginning of spring, and as a sign thereof the Swallows are again appearing: they have been seen in town three or four days. I had the pleasure of seeing my first Swallow in Tasmania yesterday (August

* Vide Zoologist for I868, pp. I IO5-I I I8. 
20), for they had only then found their way out here.'

The Swallow leaves us about the Ioth of October, though a few stay on until the 2oth of the month, and the bird has occasionally been seen even in November. The Rev. C. Wolley tells me that he observed a single specimen as late as the I 6 th of that month, in I866; and in 1867, one of Her Majesty's park-keepers informed me that he saw several Martins and Swallows at the beginning of November skimming over the river near the Albert Bridge, Windsor.

A Swallow built her nest in a belfry a few summers ago, and was always observed to sit perfectly still upon her eggs when the bell rang, although the nest was only a foot distant from the bell, which was a loud-sounding one. Mr. Gould says in his 'Birds of Great Britain:' 'I find by my note-book that some Swallows were sitting on their eggs under the little romantic bridge at Formosa, near Cookham, Berkshire, as late as the 8th of August.' This, however, does not seem to me very late, and my friend Mr. Wolley informed me that he had seen young Swallows not fledged on the 28th of Septemberseven weeks later.

A pure white specimen of this bird was for several days observed flying about Ditton Park by Mr. Paice in August 1863, and was eventually shot between Langley and Uxbridge. 
Lord Clifton, writing from Eton to the Zoologist for I 567 , states that one day in August of that year a Swallow was seen to be caught by the head in the interstices of one of the gilded weathercocks which surmount the top of a house at Eton College. Sympathising crowds of Sivallows flocked to see it, and in a short time two more were captured in the same manner.

An unusually late stay for the Swallow* is recorded in Loudon's 'Magazine of Natural History,' where it is stated that Mr. F. G. Tatem, observed two Swallows at High Wycombe on the 22nd November.

MaRTin (Hirundo urbica). This abundant species usually arrives in small companies of from five to ten or twelve, towards the end of the first or the beginning of the second week in April. Martins like Swallows have been always regarded as harbingers of spring, and their arrival is eagerly looked for by all. In the year I 867 they arrived earlier than usual. Mr. Ingram, Her Majesty's gardener at Windsor, observed several House Martins during the last week in March.

SAND-MARTIN (Hirundo riparia). A summer visitor, arriving during the first week in April in little bands, larger flocks following in a few days. It is common everywhere during the summer months, and large numbers may be seen along the banks of the Thames, where a few remain to breed. About

* For a capital account of the habits of this bird, vide pp. 324-327 of Mr. Henry Stevenson's 'Birds of Norfolk,' vol. i. 
seven years ago many annually had their nests in an old sand-pit near Salthill, but they have now forsaken this locality.

The Sand-martin, which is the smallest of the Himndines, is not so numerous as the Swallow or common Martin in the neighbourhood of Windsor. A few stragglers have been observed as early as the end of March, and they leave us in August. In I856 an immense quantity of these birds were seen in the Eton College playing-fields.

In August I867, an albino specimen of the Sandmartin was shot on the river near Marlow, by Mr. F. Wheeler.

Common SwifT (Cypselus apus). This longwinged, strong-flying bird is a regular visitor to the two counties in summer, generally arriving at a locality on the banks of the Thames known to Etonians as 'Lower Hope,' about the 3rd of May; though in some seasons a few Swifts are observed before the. end of April. This species leaves England for Africa towards the end of August, very few being seen here in September.

The Swift is numerous in the vicinity of Windsor itself, but has sadly decreased in numbers in many places throughout the two counties where it used to be common. A few pairs remain to breed every year, usually choosing an old and lofty church-tower or barn as a site for their nests. The local name for this bird is Screech or Shriek Martin. The skeleton 
of a Swift, with two eggs and remains of the nest, were taken a few years since from one of the Eton College Chapel bell-towers, where the old bird had probably been entombed while sitting on her eggs many years previously. These remains are now deposited in the school library.

Mr. W. Dalziel Mackenzie informs me that he observed a Swift at Fawley, in Buckinghamshire, during a sharp frost on the $22 \mathrm{~d}$ of December, I 860.

\section{Family-CAPRIMULGID $A$.}

NightJar (Caprimulgus Europous). The Nightjar is the only nocturnal bird among the summer visitors to Great Britain. It reaches us about the second week in May, and departs at the beginning of September. It is partially distributed throughout both counties, but is nowhere a numerous species; one of the most favoured localities is Gerrard's Cross, near Beaconsfield, where these birds may be often heard on a still summer's night.

The female deposits two beautifully marked eggs, marbled grey or brown, in a slight depression in the ground, which serves as a nest. Many of these eggs are annually taken from the woods near Beaconsfield, and brought to Eton, where they are sold for a trifling sum.

The Nightjar is locally named Night Hawk, Screech Hawk, and Goatsucker, the latter name being 
given it from its supposed heinous crime of sucking the udders of goats and cows, whereas the true cause of its presence near the cattle may reasonably be attributed to its eagerness to capture the insects which they disturb. Mr. R. B. Sharpe states that a Nightjar was killed near Cookham Dean, as early as the 3rd of March, I867. Mr. Mackenzie tells me that the Nightjar is very rare in his neighbourhood, but that he shot one at Fawley, on the I8th of July, i 863 .

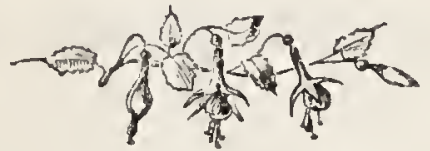




\section{ORDER III.-RASORES.}

\section{Family-Columbide.}

Turtie DOve (Columba turtur). A regular summer visitor from Africa, arriving here about the bcginning of May, and leaving us again in Scptember. A few pairs breed every year in Windsor Forest; near Wantage the species is annually observed, as well as in Ditton Woods, and in Langley and Stoke Parks. The Rev. F. O. Morris states, on the authority of Mr. Dalton, of Worcester College, Oxford, that the Turtle Dove breeds in Bagley Wood, in Berkshire.

I took a nest, five or six years ago, in Ashridge Park, which is partly in Buckinghamshire and partly in Hertfordshire; these birds were not uncommon there. It has been procured near Chesham, and Mr. Sharpe includes it in his list of the birds of Cookham. It is fairly numerous in the beautiful woods at Cliefden, and in some of the plantations around Reading its soft cooing may be heard. The Rev. Charles Wolley told me of a Turtle Dove's nest which was built in a tree in the Eton playing-fields, 
in 1865 . Specimens are shot every year near Maidenhead, Aylesbury, Taplow, and Newbury; in fact, there is, in all probability, no locality in either county in which it has not been obtained. Nine were shot by a man near Eton in a couple of hours one day, A man named Drye shot nineteen during one summer in Windsor Park, and persecuted as it is, it is surprising that this poor bird is not far less common. The Turtle Dove is a lovely bird, and ought surely to be protected; it has ever been regarded as the emblem of peace, fidelity, and love; thus that old lover of nature, Shakespeare, says,-

'Modest as the Dove.'

Taming of the Shrew, Act iii. Scene 2.

'The Dove and very blessed spirit of peace.'

Henry IV. Part I. Act iv. Scene I.

'As true as steel, as plantage to the moon, As sun to-day, as Turtle to her mate.'

Troilus and Cressida, Act iii. Scene 2.

'So Turtles pair

That never mean to part.'

Winter's Tale, Act iv. Scene 3.

There is a paragraph in the Rev. Leonard Jenyn's 'Manual of British Vertebratæ,' which I cannot explain :- 'The spotted-necked variety, ${ }^{*}$ first noticed

* Since writing the above I received a letter on this subject from my friend Mr. J. E. Harting, of Kingsbury, who says, 'Donovan, in his work on British Birds, has figured a species of Turtle, under the name of Columba albonotata, plate I49. Latham, in his "History of Birds," has referred to it as a variety of the Common Turtle. 
by Dr. Latham, appears only to have occurred in Buckinghamshire.' To what variety can Dr. Latham have alluded?

The specimen from which the plate was drawn was said to have been shot in Buckinghamshire. This is probably the bird to which you refer.'

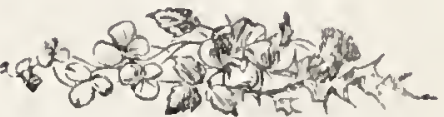




\section{ORDER IV.-GRALLATORES.}

\section{Family-CHARADRIIDÆ.}

Great Plover (Edicnemus crepitans). The Stone Curlew, Thick-knee, or Norfolk Plover, is a summer visitant to Britain. Formerly it was numerous on the downs and hills of Berkshire, and even at the present time it cannot be called a rare bird in either county.

Specimens have been procured in Langley Park at various times, and young birds have been sold in Eton. I received a notice of one that was killed near Newbury. The species used to be very numerous on the chalk downs in the neighbourhood of Ivinghoe and Drayton Beauchamp, Bucks; and my friend the Rev. Harpur Crewe sent me a note to the effect that it may still be often heard whistling over head on a still summer's night near the latter place.

Mr. A. Collins, of the 57th Regiment, in a letter to me dated November 22, I 867, says :- 'We also had a Stone Curlew (AE.crepitans) for some time in the walled-garden at Betterton, near Wantage. It was chopped by our bailiff's spaniel, when half fledged 
on one of the stony uplands, and eventually escaped, when a report was spread by an excited plough-boy, that he had seen an ostrich running towards Whiffle's farm.' This young bird was, no doubt, bred on the downs near Wantage.

The Thick-knee has been seen near Reading, and Mr. W. Hewet says that the young ones are very sood eating, but the old birds are dry and tough.

It has occurred near Aylesbury and Buckingham; and several specimens have been seen at Slapton; and Mr. Burgess tells me that its cry has been heard in the vicinity of Chesham.

$$
\text { Family-SCOLOPACID K. }
$$

Common Sandpiper (Totamus hypolcucos). Provincial name, Summor Snipe. A regular summer visitor. It may be observed on the banks of the Thames early in April, and it remains by the riverside during the summer, departing towards the close of September.

This pretty little wader is common by the sides of ditches and large streams all through the summer. It occurs near Wantage; and Mr. H. Harpur Crewe tells me that one or two pairs remain about the reservoirs at Marsworth and Wilston all the year. They are numerous by the banks of the Paddington Company's canals in summer; and the Rev. Bryant Burgess was good enough to write me word that he 
has repeatedly observed a pair of these Sandpipers in the summer months near Chesham and at Slapton, from both of which places he has a specimen in his collection. It frequents the Chess, the Colne, and the Kennet, and breeds near all these rivers, but the nest is a hard one to find.

\section{Family-RALLID E.}

Landrail (Crex pratensis). Local name, Com Crake. Reaches these counties about the middle of April, after which month it is a very numerous species.

Mr. Lillywhite, jun., of Eton Wick, told me that a Landrail allowed herself to be taken up in his hand without offering any resistance, on the 24th of September, I867. This species leaves us towards the end of August, but a few are sometimes killed in September by gentlemen out partridge shooting.

It rarely remains with us through the winter; but on Christmas Day, I865, one of these birds, in very poor condition, was picked up in a field on the banks of the Thames, near Eton.

SpotTed CRAKe (Crex porsana). This is by no means a common bird, and of local habits, but a great number escape notice by hiding themselves in dense reeds and overgrown ditches.

A pair were shot between Eton and Surley about three years since, and were preserved in Windsor. 
Another, now in the collection of Mr. Ferryman, at Datchet, was found dead one day in the spring of I 864 under the electric telegraph wires near the Slough station, against which it must have flown with great violence, its neck being gashed across. One was taken near Newbury a few years ago; this Crake has also occurred at Datchet. It has been shot at Maidenhead, and in the neighbourhood of High Wycombe. The species has been frequently killed on the banks of the Thames, where it is no doubt far more common than is usually supposed, as, by reason of its retiring habits, it is rarely seen in the daytime.

It usually arrives here in the beginning of April or towards the end of March, leaving us again in October. Water insects, seeds, and worms form this bird's chief food. The following extract from a letter from Mr. W. H. Power to Mr. J. E. Harting, is extracted from the latter gentleman's work upon the 'Birds of Middlesex :'-

'I shot one of these birds,' says Mr. Power, 'at West Drayton, as it was crossing the river Colne, which here divides the counties of Middlesex and Buckinghamshire. My dog started it from an osierbed full of tall reeds, and I killed it under the impression that it was a young Moor-hen. This was on the $2 \mathrm{~d}$ of August, I860.'

Mr. Harting justly claims this bird, and so do I; for it was shot on the borders of the two counties. 
A male of this species was shot by a man named Bunce, as late as October I867, near Monkey Island; and Mr. Shergold killed another there in September I 864.

'Oly, bolcome Spring! oly, forelcome bernal flotoers!

(1) If, focleomer than all, the mexty biro

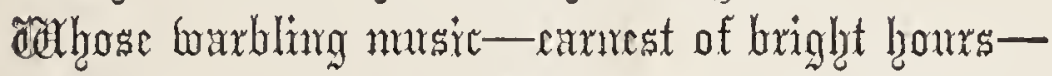

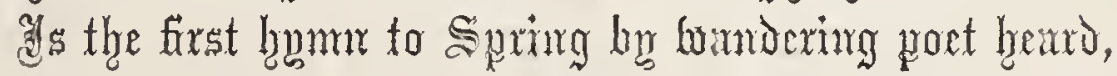

Calder Campjel.i.

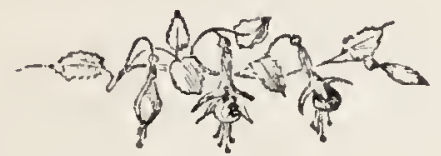




\section{WINTER VISITORS.}

\section{$-28$ \\ ORDER I.-R A P T O RES.}

Family-FALCONIDA:

Merin (Falco AEsalon). The Merlin is not a common hawk here, although individuals have been observed and taken at various times, and generally in the winter months, in different parts of the two counties.

I find by a reference to my note-book, that upon the 2 Ist March, I867, I saw a fine male Merlin which had been trapped by one of the keepers in Windsor Great Park a day or two previously. This bird, which I saw in the flesh, was in cxcellent condition. Mr. Fisher, of High Strect, Eton, had procured it for the purpose of preserving.

Another fine specimen was shot in Berlkshire in the early part of the year 1867 : it was an adult male in full plumage, and was taken by the person who shot it to Mr. Hasell, of Windsor, by whom it was preserved. 
Mr. R. B. Sharpe informed me that the Merlin has occasionally been observed in the neighbourhood of Cookham; and he has received the eggs from Woburn a village about two miles to the north-east of Cookham. At Billing Bare, which is some ten miles from Cookham, Mr. Briggs has noticed that it was not uncommon, and he was once witness to a remarkable instance of this bird's audacity. He was standing near a thick bush on the Billing Bare estate, when a Chaffinch dashed into the thicket, closely pursued by a male Merlin. Nothing daunted by his presence, the hawk as quickly followed, and, dragging the unfortunate Chaffinch out, was carrying it off, when a well-aimed shot from Mr. Briggs put an end to his carecr. In this case the Chaffinch was quite dead, perhaps killed by the shot; but Mr. Briggs stated that in many instances when he had seen hawks flying with a bird in their talons, and had fired at them-though far out of shot-in order to make them drop their prey, he had seen the birds fly away unhurt when released by the hawk.

Mr. Frank Collins, of Wantage, informed me of the occurrence of a Merlin near Wantage, in the month of October I867; his brother shot it, and had it preserved. A bird-stuffer in Windsor told me that he had had several specimens from various parts of the county of Berkshire; and Mr. Hasell informed me that a fine male was brought to him in the summer of $\mathrm{I} 867$, which had been shot by a person at White Waltham. 
The Rev. F. O. Morris, in his work on British Birds, states that he shot a beautiful female Merlin, many years ago, while walking along the side of a brook in Berkshire. Its plumage was very similar to the stones on which it fell-a novel interpretation of one of its local names, Stone Falcon.

\section{Family-STRIGIDA.}

SHORT-EARED OwL (Otus braclyotos). This biru, although not numerous in either of the two counties, is still far from uncommon in winter. I have seen them in the woods near Ditton Park; they are procured occasionally in Windsor Forest, and many other localities. It is locally named the Woodcock Orel. Mr. Ferryman, of Datchet, informed me that many were brought to him in I 860 and $186 \mathrm{I}$, but few since. Specimens have been killed at Chesham, and in the neighbourhood of Drayton Beauchamp. This bird arrives towards the end of October, and may then often be seen in stubbles. It visits England about the same time as the Woodcock, whence its name.

Mr. R. B. Sharpe states that it is rare in the neighbourhood of Cookham, but Mr. Darby killed a specimen of this Owl, some ycars since, near Cockmarsh, which was stuffed by Mr. J. Ford, of Cookham. 


\section{ORDER II.-INSESSORES.}

\section{Tribe-Dentirostres. Family-Merulide.}

Fieldfare (Turdus pilaris). Local names, Felt, Feltfare. This is a regular winter visitant to this country. It usually arrives in Berkshire and Buckinghamshire during the first week of November; in some seasons it visits us in small flocks during October. Upon the morning of the 25th of September, I867, while standing in Mr. Fenwick Hele's garden at Aldeburgh, in Suffolk, I was greatly surprised, on looking up accidentally, to perceive a small flock of Fieldfares flying towards the south-east; several persons saw them besides myself, and I am fully persuaded as to their identity. Several friends informed' me that they saw birds of this species in various parts of England during the last week of September I 867. This very early migration from the north is said to be a certain sign of an unusually severe winter.

In I866, I saw the first Fieldfare at the end of October; and in I867, I was informed that some were seen in Buckinghamshire in September. This 
was probably correct, as they were observed in other counties about the same date.

They generally leave us towards the end of March.

ReDwing (Turdus iliacus). Local name, Red Thrush. This bird arrives here from the north in the middle of October; it generally makes its appearance about the 2oth of that month, but I have occasionally known them to arrive earlier.

They are often to be seen in the neighbourhood of Windsor, feeding in flocks on the moist ground bordering on the Thames, and I have observed large numbers of this species in a part of Windsor Great Park known as 'Queen Anne's drive,' as late as the beginning of April. They leave us for the most part at the end of February, or early in March.

\section{Tribe-CONIROSTRES. Family--FringILLID A.}

BRAMBLING (Fringilla montifringilla). Locally called Bramble-finch or Mountain-finch. A regular winter visitor, appearing in far larger numbers in some years than in others. The first flocks usually arrive towards the end of November, occasionally being observed in October, and leaving us again at the close of winter. The Rev. H. H. Crewe states that this bird appears in vast flocks during the late autumn, winter, and early spring months in the neighbourhood of Drayton Beauchamp, Buckinghamshire, for the purpose of feeding on the beech-mast. 
In very severe weather it feeds and associates with Sparrows, Chaffinches, and other birds in the farmyards. Large numbers visit Windsor Forest every winter, and a great many are shot for specimens. I have seen birds of this species which had been shot near Eton, at Chalvey, Eton Wick, Surley, and Datchet. Numbers visit Burnham Beeches annually, and there they find an ample feast of their favourite food. In mild winters they are not so numerous, but I never knew a season in which some did not occur. I have seen them in the beginning of April, although the greater part leave us in March.

A great number are taken by bird-catchers every season. The birds are observed near Newbury, at Chesham, Hungerford, Maidenhead, and Reading, and I might give a long list of places at which I have received notices of their occurrence. Mr. Gould, in his 'Birds of Great Britain,' observes that 'tens of thousands of Bramblings may now (25th March, I865) be seen at Stoke, Cliefden, and Dropmore, in Buckinghamshire; and he states that they may be found at Reading any spring, when they throw off their shyness. Mr. F. Collins sends me word that they are seen at Betterton, near Wantage, every year. The following is an extract from a note from $m y$ friend Mr. J. E. Harting, the author of the "Birds of Middlesex :-

'With reference to the occurrence of the Brambling (F. montifringilla) in Stoke Park, Bucks, this letter 
from Mr. A. G. Atkins of Farnham Court, Slough, appeared in the Times of the 23rd of March, I 865 : "Some of your readers may be interested by the mention of a fact which in this neighbourhood, at least, is without parallel in the memory of the oldest inhabitant. A large flock of Bramble-finches have taken up their residence in Stoke Park. Their numbers may be estimated when I state that the flight, which was seen starting from their roosting-place one morning, continued strcaming on without interruption for thirty-five minutes. The person who noted this killed forty-five at one shot. I may mention that before they came to their new quarters, thousands of Starlings congregated there nightly, but since this invasion of northerners the ancient inhabitants have been dispossessed; but they have not forgotten their former homes, and now that returning spring has warned our new friends to seek more quict quarters before pairing and building time comes upon them, the Starlings are again making their appearance in great numbers."

The Brambling is found at Pangbourne and Abingdon, and Mr. R. B. Sharpe informed me that in winter these birds frequent the woods at Dropmore and Cliefden, where they roost, but as soon as it is light they fly off in flocks to Quarry Wood, near Marlow, where they find plenty of beech-mast.

Bramblings are taken at High Wycombc annually, as well as near Uxbridge and Aylesbury. A remarkable fact connected with this bird occurred at Eton; 
some time ago. I give the extract verbatim, from my note-book:-

'Upon the evening of the Ioth of March, I867, at a little past eight o'clock, a bird flew into a room in this house, at Eton, through the open window: I found that it was a Brambling. It is a curious thing for one of these little birds to fly straight into a room at night, and I am inclined to think that it had been caged before, as it made no effort to escape, although there were no signs upon its plumage to justify the supposition that it had been kept in confinement. It is now in a cage, and apparently in excellent health.'

Bramblings often resort in winter to Langley Park, near Slough, and they have been observed at Beaconsfield and Fulmer, and on the Chiltern Hills.

Siskin (Carduelis spimus). Arrives here towards the end of November from the north, and remains with us throughout the winter months, taking its leave as spring returns.

During severe winters it is more plentiful than in mild ones, and in some seasons it comes in immense flocks, while in others very few are to be seen. Many are taken by professional birdcatchers in the vicinity of Eton and Windsor every season. It is a tameable and very active bird, forming an attractive addition to an aviary. It is sometimes seen in flocks, consorting with linnets and other small birds. Mr. Sharpe writes me word that this species is not 
uncommon near Cookham during the winter; and it has becn seen near Reading, Surley, Maidenhead, and Wantage. The Rev. B. Burgess tells me that it occurs at Chesham and Slapton; and Mr. H. H. Crewe states of this species that Baldwin, a birdcatcher who lives near Drayton Beauchamp, not unfrequently captures the Siskin in his clap-nets, during the winter months, in that neighbourhood.

In the winter of I 857 a great number of Siskins were captured in Windsor Great Park, and the species were likewise numerous in the hard winter of I 866-7. Mr. Wolley saw five of these birds near Surley lock, for several days in the month of February I 867. In Mr. Gould's work on the 'Birds of Great Britain,' he observes that he has often known large troops of Siskins to frequent Taplow and Cliefden woods. In the parks at Langley and Stoke it is not uncommon in cold weather.

The food of the Siskin consists chiefly of various seeds, and it is an interesting sight to see a flock flying from tree to tree and passing from branch to branch, eagerly searching the alder, birch, larch, and other trees, for the hidden food. It very rarely breeds in this country, but the nest has been taken in Aberdecnshire, near New Abbey in Galloway, and in some other parts of Scotland.

Lesser Redpole (Linota linaria). Provincially called the Common Redpole. A winter visitor. It is never very common, but small flocks begin to 
frequent the banks of some of our smaller streams and rivulets about the end of November. These flocks leave again for their northern breeding stations in March. Though instances have been recorded of this species nesting in southern counties, I have never been able to meet with an authenticated nest in either Berkshire or Buckinghamshire.

This bird may be distinguished from the Mealy Redpole by having its tail feathers not nearly so long or so deeply forked as that bird: it is also smaller in size.

Mountain Linnet (Linota montium). Like the last-named species, this is also a winter visitor, but not so abundant. It is more frequently found on hillsides and moors, and is on this account less common in Buckinghamshire and Berkshire. Its food consists almost wholly of seeds. This bird is distinguished from the common Linnet, and both the Redpoles, by its yellow bill, by the greater length of its tail, which is also more forked, and by possessing a reddish throat, without any red on the breast or head which is characteristic of the other species.

Common Crossbill (Loxia curvirostra). This remarkable-looking bird is a winter visitor, but never appears in any great numbers, although in some seasons it is more common than in others. As it is not a regular visitor, it may be interesting to enumerate here the dates and localities of its occurrence which have come under my notice. 
Mr. Sharpe tells me that a few are seen in the neighbourhood of Cookham nearly every winter, but it is not common there at any time. About the year I 847 , several birds of this species were shot in the grounds of Drayton Lodge, and were placed in the collection of Mr. S. W. Jenney, for a notice of which I am indebted to the Rev. H. Crewe. It has been observed in the plantations at Fulmer, and is reported to have been seen in Burnham Beeches. Five were shot late in the autumn of $S_{57}$ near Virginia Water, and were taken for preservation to Mr. Hasell, of Windsor, who told me that a single bird of the same species was brought to him from the same locality in the winter of I866. A male Crossbill flew into a room in a house near Reading a few years ago, and a female bird of this species was seen sitting in a tall hedge in the road between Eton and Datchet, by Mr. J. Clayton, of Eton, carly in the morning of the 3oth of November, I 867 . Mr. James Williams shot a pair near Aldbury a short time ago, and it has been taken at Risborough.

\section{Family-CORVIDA.}

HOODED CROW (Corons comix). Locally termed Royston Crow. May be observed along the banks of the Thames every winter. This crow is excecdingly wary, as those who have attempted to get a shot will doubtless have discovered. A few, however, 


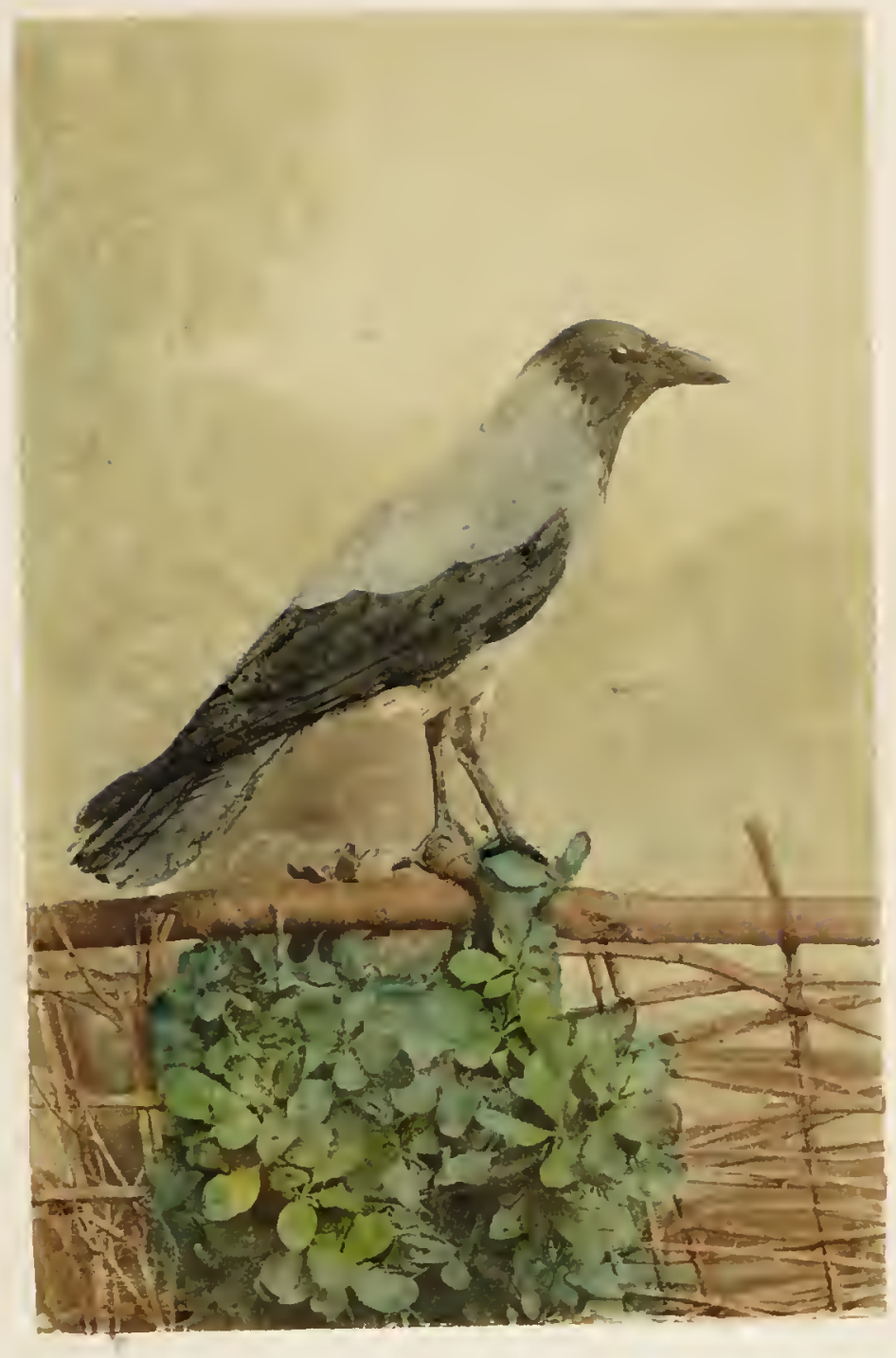

THE HOODED CROW.

corrus cornix. 

are generally killed during the winter season in the neighbourhood of Windsor, Cookham, and Maidenhead.

At the large reservoirs near Drayton Beauchamp, this species is common in winter. It is also found during frosty weather in the neighbourhood of Chesham. Besides being wary, the Royston Crow possesses a great amount of cunning, as the following anecdote will show.

A friend was driving home one evening, when he observed one of these Crows feeding on a dead sheep by the roadside: he shot it, picked it up, and placed it carefully in the bottom of the carriage-apparently quite dead. He had not proceeded far when on hearing a noise behind him, he looked round and was surprised to see the bird sitting on the backrail of the vehicle; on stretching out his hand to recapture it, to his amazement the Crow flew away. $\mathrm{He}$ watched it for some distance, and as it flew strongly and well, it appeared evident that the bird had been only shamming. 


\title{
ORDER IV.-GRALLATORES.
}

\author{
Family-CHARADRIIDE.
}

Golden Plover (Charadrius phuvialis). A regular winter visitor to our open marshy grounds and the banks of the Thames. Flocks generally arrive in November, at which time two or three hundred may be occasionally observed feeding on the fallow lands near Datchet and Slough; and great flocks continue flying over Eton at intervals throughout the winter, until March.

In cold weather the Golden Plover may be found throughout the two counties, and the Rev. H. Crewe told me that it is particularly common about the low meadows in the vicinity of Drayton Beauchamp in winter; and it is not rare at Chesham, Cookham, and Risborough.

$$
\text { Family--SCOLOPACIDA: }
$$

WoODCOCK (Scolopax musticola). There is no good Woodcock shooting to be had in either county, although this bird is a regular winter visitor, arriving towards the end of October in small detachments. 
The Woodcock is an early breeder, but does not often remain to breed in this country. However, the nest has been occasionally taken here. Mr. Royce found a nest of this bird, in I857 or I858, with eggs, in Winkfield Park. The eggs have been taken near Beaconsfield, and I procured a good example from a wood near Burnham in the spring of 1867. A few pairs have been known to breed for several successive years near Stoke ; and this bird has nested in Newwoods, Burnham, for several seasons. The Rev. H. Burney, of Woburn, wrote Mr. James Britten word that the Woodcock breeds in the woods at Brickhill, near Woburn, nearly every year. This bird leaves us, as a rule, about the end of February.

Mr. Dalziel Mackenzie tells me that he saw eight Woodcocks on the I3th of December, I859, near Fawley, and one of these birds he saw perch on a large oak, where it remained until disturbed.

Common Snipe (Scolopax gallinago). This wellknown bird is a winter visitant, and in hard weather a good many couple are shot along the banks of the Thames and other rivers, and it may generally be obtained wherever there is any marshy ground. The nest of the Snipe is a very slight structure, and is placed on the ground, well concealed in long grass, generally in the vicinity of water. A nest has been several times discovered on East Burnham Common, where eggs of the Woodcock have also been taken. Snipe's eggs have been procured from open 
commons in the vicinity of Reading and on the southern borders of Berkshire. In the severe winter of I 866-67, during the hard frosts which then prevailed, Snipe were so tame as to sit on cottage door-steps, and when disturbed did not fly far.

They are sometimes killed by flying against telegraph wires, and in a similar way I have known Landrails, Redwings, Blackcocks, and Larks to mect thcir death. On the 7 th of December, I 867 , I was shewn a Snipe which had bcen killed in this way, near Windsor, one wing being cut clean off, and a deep gash on the head.

The following is from a letter from Mr. Mackenzie:' I saw a Snipe shot out of a flock of Larks at sixtythree yards on the hills near Fawley, on the Ist of November, r862. I saw a Snipe on the 2oth of July, I 862, which is unusually early, or late, unless it was breeding.'

JACK SNipe (Scolopax gallimila). A beautiful and well-known species, but not so numerous as the lastnamed, although, like it, a regular winter visitor. So far as I am aware, no authenticated instance of its breeding in Great Britain has ever becn recorded.

It reaches us in October, and remains until February. In the neighbourhood of Chesham it is rarc, but Mr. Bryant Burgess told me of one which was shot near there, at Missenden, in the month of February, I 842, and of another which was killed ncar Slapton in December, I 848 . 


\section{ORDER V.--NATATORES.}

\section{Family-ANATIDE.}

Bean Goose (Anser segetum). All the geese which have occurred in these two counties were observed in winter, and I am enabled to include in my catalogue no less than eight species; viz. the Grey-lag Goose, the Bean Goose, the White-fronted Goose, the Bernicle Goose, the Brent Goose, the Egyptian Goose, the Spur-winged, and Canada Goose, a list of which any inland county may well be proud.

The Bean Goose not unfrequently occurs in hard weather on the Thames, and is one of the commonest of the wild geese which have been observed here. Small flocks are occasionally seen in winter flying high in air in the shape of the letter $<$ placed horizontally, and I believe that in the majority of cases a near inspection would have proved these to be Bean Geese. Several of this species were seen and killed in the vicinity of Windsor and Surley in the hard season of I866-67; indeed, almost every winter a few are shot in this neighbourhood. It is not rare in cold weather, on the canal at Slapton, and has also occurred at Chesham and other places. 
Brent Goose (Auser torquatus). This, the smallest of the British geese, has been shot in many localities in the two counties, but it will perhaps not be uninteresting if I enumerate the instances of late years of its occurrence. In I 865 , a person named Bunce shot a pair of these geese near Datchet; and it has been obtained on many other occasions in the vicinity of Windsor and Eton. One was killed on the Thames near Eton during the hard winter of I 866-67. Mr. Sharpe told me of one which was shot in the winter of I 866 , on the river near Cookham. In severe weather small flocks visit the large reservoirs in the neighbourhood of Drayton Beauchamp, as the Rev. H. Harpur Crewe was good enough to write me word. Two were killed at Surley by an Eton waterman in January, I 867 , and many more were seen at the same time.

Colonel Hawker observes : 'To kill Brent Geese by day, get out of sight in a small punt, at low water, and keep as near as possible to the edge of the sea; you will then hear them coming like a pack of hounds in full cry, and they will repeatedly pass within fair shot, provided you are well concealed, and the weather is windy enough to make them fly low. Before you fire at them spring suddenly up, and these awkward birds will be in such a fright as to hover together, and present a mark like a barn door.'*

Hooper (Cygmus ferus). The Hooper, Wild, or Whistling Swan, is a winter visitor to this country

* 'Instructions to Young Sportsmen.' 
and the harder the weather the more numerous is the species. This bird is more common in the northern parts of our island than in the southern counties; nevertheless a few specimens are procured every now and then, even in localities at some distance from the sea.

I received the following letter from ' a Windsor lad of I83 I :-' I remember about twenty-five years back a Mr. Hughes, connected with the Royal household, and well known in Windsor as 'old Buffy Hughes,' shooting in the neighbourhood of Clewer Point, Windsor, a couple of Hoopers or Wild Swans; and I well remember that one was converted into soup, and most of the people who partook of it were very much disturbed in their internal economy.'

In the winter of 1835 , a man named Kitson shot a Hooper near Eton, which was taken home by him and cooked for supper. Another was killed by Mr. G. S. Lillywhite, of Eton Wick, about the year I837, on a piece of ground known as Aldridge's Copse. Some were procured, twenty years since, in the neighbourhood of Burnham, by Mr. Howard of that village. In the winter of I862, a couple of Hoopers were killed at Wraysbury, and stuffed by Mr. Hasell, of Windsor. Another specimen was shot on the river in the winter of I865-66. Others have been brought at various times to the Eton and Windsor birdstuffers, but the dates of their occurrence have been forgotten.

I am told by Mr. D. Mackenzie, that seven were 
seen for some days in some meadows near Fawley and Greenlands, Bucks, during December, is6o, and January, iS6I. Two were afterwards shot at Medmenham.

One was killed on the Thames, on a cold day in I S6I, not far from Windsor; and the Rev. F. Morris states on the authority of Mr. Wilmot that a flock of five appeared in January, I 855 , between the village of Cookham and Maidenhead, of which two were shot. A few occasionally rest for a time on the river in winter before continuing their journey, but this is not often the casc. This Swan has been procured near Chesham, and at Surley, where several have been shot in severe seasons by the Thames watermen. It has also occurred at Cooliham.

In the winter of $\mathrm{I}_{3} 8$, a couple of Hoopers were shot by a bargeman named Plumbridge, just above Surley Hall; and I am indebted to the Rev. Bryant Burgess for the notice of one which was killed on the water at Latimer a few years ago, and which is now in the collection of Lord Chesham.

On the 2ist of February, r 864, five Wild Swans were seen at Fawlcy, and with them were two Mute Swans, which they had probably enticed away from some private water. The two latter were killed, but the Hoopers flew westward over the Chiltern Hills.

The Rev. H. H. Crewe states that the Hooper occasionally visits the reservoirs at Wilstone and Marsworth in severe winters. 
Many do not know the Wild Swan from the Mute or tame species, but the chief distinction is the bill, which in the domestic bird has the base brownishblack and the extremity yellow, and in the Wild Swan vice vers $\hat{a}$, the base being yellow and extremity black.

Shoveler (Anas clypeata). This handsome bird has occurred in various parts of the two counties, where it is a winter visitor, although not a common one.

In I 855 a male was killed by Mr. Newman, on the river Thames at Datchet. Another male Shoveler was shot by Mr. Howard, of Burnham, in the winter of $1862-63$, at Hay mill-pond in Burnham parish; he had it stuffed, and I examined it at his house. In I 867 an adult female of this species was procured near Wraysbury towards the end of September-an early date for this bird to come so far south. I am informed by the Rev. H. Harpur Crewe that small flocks of the Shoveler visit the reservoirs at Wilstone, Marsworth, and Weston Turville, during inclement seasons, but it is never a common bird there.

Gadwall (Anas strepera). The Gadwall, or Grey Duck, is an uncommon bird, and is only introduced here as a winter visitant on the authority of the Rev. H. Harpur Crewe, of Drayton Beauchamp, who wrote me word that this species has occasionally been killed on the reservoirs at Marsworth and Wilstone.

Montagu says that this bird is supposed to breed in Sweden and Russia, and probably in Siberia, being found in those countries in spring. The Gadwall is 
an excellent diver, and like most long-winged ducks is a bird of powerful flight. It feeds chiefly during the night, and has a loud note, not unlike the noise made by the Mallard.

Pintail (Anas acuta). Although this duck is a common winter visitor on our shores, it is not so often met with inland. The following instances of its occurrence in these counties have come under my notice.

A male Pintail, in first-rate plumage, is in the collection of Mr. Ferryman, at Datchet; it was shot on a sheet of ice in Stoke Park, by a man named Gregory, in the winter of 1863 . The female bird which was in company with it contrived to escape.

The Rev. H. H. Crewe states that this species visits the reservoirs at Marsworth, Wilstone, and Weston Turville, every winter in considerable numbers.

Colonel Montagu states that the note of this bird is very soft and inward; the courting note is always accompanied by a jerk of the head, and its other note bears a striking resemblance to the cry of a young kitten. The flight of the Pintail is very rapid.

Wild Duck (Anas boschas). Although a few pairs of the Wild Duck remain in these counties to breed every summer, for the most part this species is only a winter visitor, and in inclement seasons immense flocks pass over, occasionally dropping down on the rivers and secluded ponds to rest, until driven away by the persecutions of sportsmen. White varieties have occasionally been procured, and I have met with 
pied specimens which have been killed in the neighbourhood. A purely albino drake of this species was shot on the ornamental water in Stoke Park a few winters ago by Mr. Newman, of Datchet; and a pied Wild Duck is in the possession of Mr. Howard, of Burnham, which was killed in that vicinity.

The common Wild Duck has been known to breed in confinement with the Egyptian Goose, the Pintail and Muscovy Ducks, and the Shelldrake.*

GARGANEY (Anas querquedula). Not a common species, but my friend the Rev. H. H. Crewe, of Drayton Beauchamp, has enabled me to place it on my list of winter visitants to these counties.

The Garganey has been several times obtained on the reservoirs at Marsworth and Wilstone in cold weather, but I believe it has never been known to frequent these sheets of water during the summer months.

TEal (Anas crecca). This handsome little duck is a regular winter visitor, and is often shot on the reservoirs, streams, and rivers of both counties. The Teal does not often remain to nest in England, but I am happy to be enabled to give more than one authenticated instance of its breeding in Buckinghamshire. In the summer of I86I two nests of this species were discovered among some moss and rank herbage

* A capital account of the system of working the decoys, as practised formerly (and now to a certain extent) in Lincolnshire, Essex, \&c. is given by Yarrell in his 'British Birds,' vol. iii. pp. 265-268. 
growing by the side of a pond near Burnham: it is probable that the birds had bred there previously. The Rev. H. H. Crewe, from whom I have received so many interesting ornithological notes, informed me that he had taken the nest of this bird by the banks of the Wilstone and Marsworth reservoirs, where this species breeds in limited numbers almost every season. This statement is confirmed by the Rev. James Williams, of Tring Park, who has also taken the eggs at Wilstone.

Wigeon (Anas penclope). This species appears in limited numbers every winter on the Thames, Colne, Chess, and the Kennett. Wigeons have been shot at various times near Windsor, Eton, Cookham, Datchet, Maidenhead, Surley Hall, and other places, and have occasionally been killed on the water at Latimer, near Chesham. The Rev. H. Harpur Crewe states that immense flocks appear during winter on the large reservoirs at Weston Turville, Marsworth, and Wilstone, and $I$ have received notices of the occurrence of this bird in many other localities. The late Mr. Waterton observed that contrary to the usual habit of ducks the Wigeon feeds by day, and its food consists chiefly of grass. 'The Wigeon,' says that accurate observer, "is a much more familiar bird than either the Pochard or the Teal. While these congregate on the water, beyond the reach of man, the Wigeon appears to have divested itself of the timidity observable in all other species of wild-fowl, and ap- 
proaches very near to our habitations. A considerable time elapsed before I was enabled to account satisfactorily for the Wigeon's remaining here during the night; a circumstance directly at variance with habits of its congeners, which, to a bird, pass the night away from the place where they have been staying during the day. But, upon paying a much closer attention to it than I had formerly been accustomed to do, I observed that it differed from them all, both in the nature of its food, and in the time of procuring it. The Mallard, the Pochard, and the Teal, obtain nearly the whole of their nourishment during the night. On the contrary, the Wigeon procures its food in the day time, and that food is grass.'

My friend Captain Henry Elwes, of the Scots Fusileer Guards, tells me that a pair of Wigeons were observed frequenting the reed and osier beds on the banks of the Thames, between Windsor and Datchet, as late as the month of May, I860. They were supposed to have a nest there, but it was never discovered.

Common Scoter (Oidemia nigra). Like the lastnamed, a winter visitor, but of more rare occurrence. The flesh of this bird has a very fishy taste, and is but little esteemed for the table. Mr. Yarrell gives an interesting account, which I shall quote, of the manner in which these birds are taken on the saltlakes near Martignes, at the mouth of the Rhone. He says: 'These numerous salt-lakes are frequented in winter by large flocks of aquatic birds. With the 
first appearance of frost the Scoters and other ducks arrive in small flocks, and a destructive sort of battue takes place, in which all who can are induced to participate with great eagerness. About Christmas, when the Scoters have made their appearance, printed bills are posted at Marseilles, Aix, and all the principal places in the vicinity, stating the intended order of attack upon the birds, and the day and hour at which it is to take place. The mayors of two or three of the principal places make the necessary arrangements; on the eve of the day fixed upon all the shooters are divided into parties, and each has a boat, a pilot, and a commander appointed.

'The assemblage is large, filling the inns and the lodgings to be had at private houses. In the morning, at the sound of a drum, the embarkation takes place on the lake named for the first attempt. The boats filled with sportsmen form an extended circle around the flocks of birds at one part of the lake; the boats then draw in, diminishing the circle by degrees till the crews are within gunshot of the intended victims.

'At a well-known and preconcerted signal, a partial discharge takes place at the unfortunate birds while swimming on the surface of the water. Many are killed on the spot; those which escape this first fire attempt to save themselves by flight, when a second discharge assails them in the air; many more fall, and with broken wings and loud crics are picked up by the shooters, who divide the spoil, not without 
many altercations, and return to land. After a short respite, the birds having again collected together on that or some other neighbouring lake, a second advance takes place in the same manner, and the day is passed in making a succession of attacks, each followed by a retreat for a time to allow the birds to reassemble.**

The Scoter has been observed on the reservoirs near Tring and Drayton Beauchamp; and in the winter of 1862 , a specimen of this bird was shot while flying over a piece of ornamental water at Datchet, and was taken for preservation to one of the Eton birdstuffers. Another was procured near Cookham, in Berkshire, in the winter of 1865 , by a man named Godden, who is employed as a ferryman below Cookham bridge, and passed into the possession of Mr. Charles Venables, by whom it was unfortunately not preserved: this bird was a male, in full plumage. Mr. R. B. Sharpe wrote me word of another good example of this species, which was shot on Mr. Palmer's estate, near Reading, in the month of July, I 867 , an unusual date for the appearance of this bird inland. It was sent to Mr. Briggs, at Cookham, in order to be stuffed, but by the time it reached him it was so much decomposed as to render its preservation hopeless.

Pochard (Fuligula ferina). The Rev. H. H. Crewe states that this duck is a common winter

$$
\text { * Yarrell's 'British Birds,' vol. iii., pp. } 3 \text { I9, } 320 .
$$


visitor to the reservoirs near Drayton Beauchamp, but it is rare on our rivers, although a few have at various times been obtained during severe winters. In a letter bearing date the 6th February, Is68, my friend Mr. R. B. Sharpe observed that he had a fine male of this species in his collection, which was killed some years ago at Cookham. The Rev. Bryant Burgess informed me of another Pochard, also a male, in his possession, which was shot at Ivinghoe Aston in February, I 847 . Several birds of this species were obtained near Windsor in the inclement winter of 1858 , and others have been met with in that neighbourhood more recently. The last Pochard which came under my notice was a male bird, now in the collection of Mr. Sharpe, which was shot on the river at Cookham on the $\mathrm{I} 3$ th of January, i 868 . The Rev. H. H. Crewe states that the Pochard has, on two occasions, been known to breed on the water near Drayton Beauchamp. A nest containing eggs was taken in June, I 850 , at the Marsworth reservoir by a gamekeeper of the Rev. James Williams, of Tring Park: and a few years later, a pair of Pochards nested on the banks of the same piece of water. Fortunately, these birds were allowed to hatch out their eggs in security. The Rev. J. Williams, to whom I have just referred, has taken Pochard's eggs at the Wilstone reservoir, where he believes that this species, in common with the Teal, breeds in limited numbers every year. 
SCAUP DUCK (Fuligula marila). An uncommon winter visitor here, although often enough procured during hard weather on the sea-coast, and at the mouths of rivers. It is a very expert diver, and its food consists of aquatic plants, insects, and mussels. From the nature of its food its flesh is naturally coarse and tough, and hence it is held in no estimation for the table. On the 26th of January, I855, the Rev. B. Burgess observed a female Scaup Duck swimming about in company with Coots and Dabchicks on the water in the park at Latimer, near Chesham, which was not frozen; and a few days afterwards Mr. Elliott, of Chesham Bois Mill, sent him a Scaup which he had just shot on the stream. The Rev. H. Crewe states that it is an occasional winter visitant to the Wilstone reservoir; and I have no doubt but that specimens have been killed on the Thames at various times.

TufTed Duck (Fuligula cristata). The Tufted Duck, or Tufted Pochard, is a common winter visitant at the Marsworth and Wilstone reservoirs, but it does not so often occur on our rivers. The Rev. B. Burgess informed me that Mr. Elliott, of Chesham Bois, sent him a Tufted Duck one day in February I 855 , which had been shot on a stream of water in the neighbourhood. Mr. Burgess states that he has repeatedly observed these ducks on the water at Latimer. Mr. Hasell, of Windsor, received some Tufted Ducks for preservation which were shot 
in Berkshire in the winter of I $\$ 58-59$, and he told me of others which were obtained on the river near Windsor in I 864 and i $\$ 65$. Mrs. De Vitré's collection of stuffed birds at Formosa contains a fine male Tufted Duck, which was shot by Mr. J. Ford during severe weather some few winters ago.

Mr. Dalziel Mackenzie, of Henley, has informed me that he has known of several ducks of this species which have been killed on the Thames in severe winters.

GOLDEN-EyE (Fuligula clangula). A winter visitant, but never appearing in any great numbers. It is a handsome species, and an expert diver. Owing to the nature of its food, the flesh is not very palatable, and the Golden-eye therefore, is held in little estimation for the table.

The Rev. H. Harpur Crewe informs me that it is a regular visitor, in winter, to the reservoirs near Drayton Beauchamp, appearing in larger numbers according to the severity of the scason. About the year I 854 , three of these birds were shot out of a little flock by Mr. S. Hall, of Windsor, on the Thames at Boveney Lock. Mr. Hasell told me that he had a pair of Golden-eyes about ten years ago which were shot at Wraysbury. I have seen several preserved birds which had been killed near Eton, Datchet, Surley, and Windsor. My friend, Mr. R. B. Sharpe, told me that the Golden-eye is often found in the neighbourhood of Cookham during severe 
weather and when floods are prevalent. Mrs. De Vitré's collection at Formosa contains a fine male of this species which was procured in the immediate neighbourhood, and Mr. Briggs once saw a flock of five of these ducks swimming about some flooded meadows near Cockmarsh.

Red-Breasted Merganser (Mergus serrator). A winter visitor, though not common. The Rev. H. Harpur Crewe informs me that small parties of four or five are observed upon the reservoir at Wilstone almost every year. Octasionally individuals are shot on the Thames.

A pair of Red-breasted Mergansers are recorded as having been killed near Reading, so long ago as I785. A female of this species was shot at Wraysbury in the winter of $\mathrm{I} 854$, and was stuffed by Mr. Hasell of Windsor. I am indebted to Mr. R. B. Sharpe for the notice of a female Red-breasted Merganser, which was killed during a frost a few years since in the neighbourhood of Cookham, and is now in the collection of Mrs. De Vitré.

Goosander (Mergus Merganser). Local names, Saw-billed Diver and Dun-Diver. An uncommon winter visitant. Of late years the following particulars of the occurrence of this species have come under my notice.

In I 847 a carpenter killed a fine male on the Thames, near Monkey Island: this bird is now in the collection of Mr. Harding. An adult male was 
obtained at Wraysbury in the winter of 1856 : this specimen was preserved by Mr. Hasell, of Windsor. A female, in excellent plumage, was procured on the river near Datchet, in the winter of I\$60. Many years ago several were taken near Windsor, and brought to the Windsor taxidermists for preservation. A female was shot by Mr. G. Lillywhite, of Eton Wick, at Boveney Locks, in January, IS64, while cndeavouring to elude the attack of some Swans. A man named Godden, who has charge of the lock at Cookham, has a Goosander which he shot in that neighbourhood in the winter of I 866 . One was seen on the Thames, near Eton, by a working man, late in the afternoon of the 3 I st of October, I 867.

Scarcely a winter elapses in which a few Goosanders are not shot on the Thames; and in hard weather this species is often found on the reservoirs near Drayton Beauchamp.

\section{Family-COLYMBID e.}

Sclavonian Grebe (Podiceps commutus). Also called the Horned and Dusky Grebe, the latter name being probably given to it from the sombre colour of the immature plumage.

In the winter of $185 \mathrm{~S}$ a Sclavonian Grebe was shot in the neighbourhood of Windsor, and was taken for preservation to Mr. Hasell of that town, who informed me that he had had several which had been taken at various times in Berkshire, but none of these 
were in the summer dress. Another specimen, in very fair plumage, was killed on I 7 th January, I86I, on a quiet pool known as Charley Tull's pool just below the Windsor weir on the Thames. This bird was shot by Mr. H. Taylor, and is now in the possession of Mr. Harding, of Eton. A birdstuffer at Windsor, by name Hall, was driving by the Victoria Bridge, on the Thames, in the early part of 1858 , and observed a Sclavonian Grebe on the wing; wishing to obtilin it for his collection, and not knowing at the time what bird it was, he went home and returned in about half an hour with his gun. He then saw the bird swimming about in the middle of the river, and was about to shoot it, when his brother, who had accompanied him, advised him to send in his retriever to endeavour to catch it, or make it rise, and thus get a better shot. The dog accordingly went in and swam up to the Grebe, which, curiously enough, did not attempt to escape by flying or diving, but allowed itself to be caught and brought to land. It was then found to be a fine male Sclavonian Grebe. It is still, I believe, in Mr. Hall's possession.

With respect to the present species, Mr. Sharpe writes to me as follows:-

'My friend Charles Venables, Esq. bought a nice specimen of the Sclavonian Grebe, which had been shot in the winter of 1865 . It was procured by a man named Godden, close to Cookham Bridge, and is still in the possession of Mr. Venables.' 
On the 9th of December, I 867 , a Grebe of this species was killed upon the Thames at Datchet, and passed into Mr. Ferryman's hands for prescrvation. About the same time I heard of another specimen of this bird which was shot on the Thames, close to Eton.

Red-TuroATED DIVER (Colymbus septentrionalis). Local name, Silver Grobe. This is the commonest of the three species of Divers, and some are killed on the river nearly every winter, especially if the weather happens to be severe. A male bird of this species, in good plumage, was killed by Mr. S. Hall, of Windsor, on the water opposite Clewer Mill: this was in the depth of a severe winter, about fifteen years ago. A young one was shot on the Thames, close to the village of Datchet, in the winter of i 863-64, and was stuffed by Mr. Ferryman. Several examples have occurred near Maidenhead and Surley; others have been shot on the river at Windsor, always in winter. Individuals have been taken at Reading and Hungerford; and a single bird of this species was procured near Burnham some years since.

A Red-throated Diver is preserved in the fine collection at Formosa, near Cookham, which was shot in the immediate neighbourhood by Mr. Briggs, a few winters ago.

An immature bird was shot opposite Tull's Lock, Windsor, by a man named Joel, in I864; it was described to me as a 'Silver Grebe,' but on inspection 
turned out to be a Red-throated Diver. Old birds of this species are seldom met with; in the majority of cases the birds obtained have been immature. An Eton birdstuffer, named Drye, informed me that he generally received a few of these Divers every year from the vicinity of Eton, Surley, and Datchet.

\section{Family-LARID}

Herring Gull (Larus argentatus). This Gull, which is numerous on many parts of our coast, occasionally strays inland during severe weather, and may then be found upon the river. Mr. Morris states, on the authority of Mr. Thomas Wilmot, that a Herring Gull was captured between Maidenhead and Windsor, on or about the 25 th of January, I 855 . In the hard winter of I 866-67 several were observed flying over the flooded fields between Surley and Eton: and this species has occurred at other times, but I am ignorant of the dates.

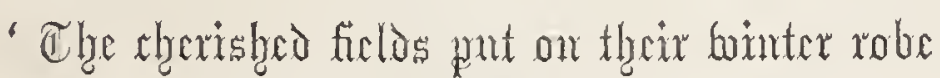
(1) f purest tolgite. Tlyc folonls of bratoen,

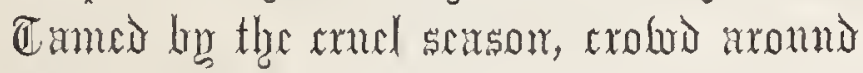
The twinnobring stox, and claim the little boon eathich gatrobiocnte assigns them.'

Thomson.

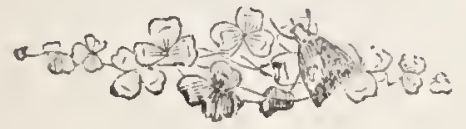




\section{SPRING AND AUTUMN VISITORS.}

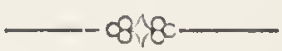

ORDER II.-INSESSORES.

Tribc-Dentirostres. Family-Merulide.

Ring Ousel (Turdus torquatus). A passing visitor in spring and autumn, but never appearing in any numbers, and generally considered a rare bird in these counties.

A female of this species was shot at Risborough in the spring of 1840 , and is now in the collection of the Rev. B. Burgess; who informed me that he saw a male in his garden, at Latimer, near Chesham, on the 9th of September, I862. A pair of Ring Ousels were observed during the same autumn at Dundridge, and in the neighbourhood of Wendover.

In I 865, a fine male Ring Ousel was killed on the Bath Road, Burnham, by the gamelieeper of Mr. G. Howard. Several of the Eton birdstuffers state that specimens of this bird have passed through their hands at various times, but they are unable to specify any dates. Mr. George Lillywhite shot a 
Ring Ousel a few years ago at Eton Wick; and I have lately examined two stuffed specimens which were procured near Windsor about twenty years ago. A male Ring Ousel was procured at Cookham Dean, near Cookham, early in the spring of 1867 , as I was informed by my friend Mr. R. B. Sharpe; who added that Mr. Brown, of Cookham Dean, had another specimen in his possession, which was shot a few years since in the neighbourhood of Stoke.

The Rev. H. Crewe states that a few Ring Ousels are observed every year during the vernal and autumnal migrations, in the neighbourhood of Drayton Beauchamp:

The Rev. F. O. Morris says that he has seen one or two Ring Ousels in the parish of East Garstone, near Lambourne, in Berkshire. One of these was killed by the late Rev. Henry Boys. 
ORDER III.-RASORES.

Family-TETRAONIDA.

Common Quail (Cotmmix onlgaris). A visitor in spring and autumn, arriving in May and leaving this country again in the autumn. Though not common, a few are shot every autumn in both counties: a number of Quails were turned out by some gentlemen residing in the neighbourhood of Windsor, and this fact may account for the statement that the Quail is more common here than in many other localities.

The majority of the Quails which are obtained in Berkshire and Buckinghamshire are shot either in May or September, few, except semi-domesticated birds, being seen or procured in the intervening months. On the 6th of September, i 842, the Rev. B. Burgess put up a Quail in a wheat stubble near Bledlow, but did not kill it, and was unable to flush it a second time. A female of this species, in the same gentleman's collection, was shot near Eddlesborough on the rst of September, I846. Three or four Quails were killed in the parish of Wargrave, during the 
autumns of I $86 \mathrm{I}$ and I862. On the $2 \mathrm{~d}$ of September, I867, a single Quail was shot by Mr. J. T. Brown, of Eton, while out partridge-shooting on Skippit's farm, near the New Lodge, Windsor. Others have been procured near Eton in the autumn, and occasionally the species has occurred at Cookham, East Ilsley, Wallingford, Newbury, Reading, Langley Park, and Chesham. Mr. Morris states, on the authority of Mr. Hewet, that this bird is common in some parts of Berkshire, while in others it is hardly ever seen. Mr. D. Mackenzie shot one and flushed three Quails near Fawley, Bucks, on the 5th of October, I867. The nest has been taken on the moors about the Harbridge flats, on the borders of Berkshire and Surrey. A nest was cut out of a hayfield near Bolney Harpenden, in the spring of 1866.

The Rev. H. Harpur Crewe informed me that a few Quails are killed near Drayton Beauchamp almost every September. The Formosa collection contains a Quail, which was shot by Mr. Briggs, on some chalky ground near Cockmarsh, where these birds were not uncommon a few years ago.

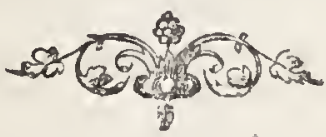


ORDER IV.-GRALLATORES.

Family-CHARADRIIDE.

DOTTEREL (Charadrins morinellus). At the end of April and beginning of May, small flocks or 'trips' of Dotterel begin to frequent many of the hills and chalky uplands of the two counties.

Mr. Gould states that they are usually found between April I5 and May I5, on the Chilton ranges of hills in Berkshire. In the spring of 1857 , a few of these birds were shot in a field near Burnham. They are rarely seen in the vicinity of Eton and Windsor; but a man named Hall has occasionally killed one or two in May, and specimens have been obtained near Datchet, and at Boveney Locks. One of the Eton birdstuffers has had Dotterel brought to him at different times, and Mr. Hasell, of Windsor, has procured a few in the month of April. Dotterel have been shot in the neighbourhood of Maidenhead and Surley. The species has occurred in Berkshire according to Yarrell, and Mr. Sharpe has known instances of its appearance near Cookham. The Dotterel has been procured in the neighbourhood of Aylesbury and Drayton Beauchamp. 
The Rev. H. Harpur Crewe has an adult male of this species, which was killed by a keeper of Earl Brownlow's, on the I4th of August, I862, in a cornfield near Ivinghoe, Buckinghamshire. The female bird was shot at the same time, but it dropped in a dell among some rushes, and was for a time lost. Some children subsequently found it, and took it home to their mother, who cooked it for dinner.

A Dotterel was shot near Reading some time since; and another was procured near Beaconsfield.

In 1856 and 1858 , several birds of this species were killed by Mr. Henry Taylor, on the banks of the river near Windsor.

Mr. Frank Collins has frequently observed these birds at Betterton, Wantage : he says they are exceedingly silly birds, and that many are shot there. As to its foolish qualities, Drayton, in his 'Polyolbion,' quoted by Yarrell, says :-

- The Dotterel, which we think a very dainty dish,

Whose taking makes such sport, as no man more can wish;

For as you creep, or cower, or lie, or stoop, or go,

So, marking you with care, the apish bird doth do ;

And acting everything, doth never mark the net,

'Till he be in the snare which men for him have set.'

I am informed by my friend Mr. R. B. Sharpe that a 'trip' of Dotterel was seen some years since on Cockmarsh Common, near Cookham.

Ringed Plover (Charadrius hiaticula). The Ringed Dotterel, or Stone-rumer, is a regular visitor to the banks of the Thames and the large reservoirs 
during the vernal and autumnal migrations: it usualiy arrives at the end of April or early in May. George Hall, of Eton, has often shot this bird near Windsor, and it is not unfrequently brought to the Eton and Windsor birdstuffers for preservation. It has becn observed near Wantage and in the vicinity of Reading, and I believe on the Chiltern Hills. Specimens have been obtained near Aylesbury, and in open fields near the large reservoirs at Drayton Beauchamp. It has been observed also at Datchet and near Maidenhead.

One was killed by Mr. H. Daly, about the ycar I848, in a field called the 'Brocas,' on the banks of the river near Eton.

I am indebted to Mr. Sharpe for a notice of a Ringed Plover which was shot by Mr. J. Ford, of Cookham, on Cockmarsh Common about five years ago.

\section{Family-Scolopacid A.}

Comion Curleiv (Numenius arquata). Provincial, Whaup. Visits the banks of the Thames and the large sheets of water near Drayton Beauchamp while on its annual migration in the spring and autumn; and occasionally a few are observed in the winter months. This bird has been shot near Chesham, Cookham, Maidenhead, Surley, Windsor, and Datchet, and from other localitics along the river I have received notices of its occurrence. Mr. Howard has occasionally shot Curlcws near Woburn, and on the Chiltern Hills. 
While walking late in autumn in the neighbourhood of Slough and Chalvey, I have listened with pleasure to the wild and plaintive note of the Curlew, which may usually be heard before the bird which utters it is seen; and I have occasionally seen a Curlew flying high in the air, over Windsor Park.

Whimbrel (Numenius phceopus).* Not so common a species as the last-mentioned, but occasionally a specimen is killed on the river in spring and autumn, at which season, as is the case with most of the Grallatores, a regular migration takes place.

The Whimbrel has been met with near Cookham and Surley; and the Rev. Harpur Crewe sent me the following note on the occurrence of this species near Drayton Beauchamp:--'A few specimens of the Whimbrel are seen almost every winter on the banks of the reservoirs here; that is to say, the Marsworth reservoir, belonging to the Paddington Canal Company; the Weston Turville sheet of water; and the canals at Halton and Wilstone.

Green Sandpiper (Totamus ochropus). The Green Sandpiper is not a common bird, but is occasionally seen during the period of the vernal and autumnal migration. Mr. Gould $\uparrow$ says that he is indebted to the Duke of Argyle for the opportunity of examining

In some counties the local name for this bird is the Titterel, from its note which Yarrell renders by the words 'tetty, tetty, tetty, tet,' which are quickly repeated.

+ 'Birds of Great Britain.' 
a very fine specimen of the Green Sandpiper, which was shot by His Grace in the spring of IS59, at Chenies, in Buckinghamshire; which, he adds, 'does not seem a suitable locality for such a bird.' The plumage of this bird was remarkably beautiful; the white of the lower parts, and the upper and under tail-coverts, were of a spotless purity. A second was shot on Dorney Common, near Eton, by Mr. S. Hall, of Windsor, in the autumn of 1863 : this was a male, but Mr. Hall saw another bird, probably the female, at the same time. Mr. D. Mackenzie informs me that he very frequently observed a pair of these birds near Fawley, in December, I864. He shot one on the $24^{\text {th }}$ of December, and the other on the IIth of February, I 865. Early in the winter of I865, two of these Sandpipers were seen on the same common by Mr. Ferry, of Eton, who shot one of them, and has preserved it in his collection.

My friend Mr. R. B. Sharpe informed me that a fine male of this species, now in the collection of Mrs. De Vitré, was shot in the winter of I 865, while flying along the Thames, near Cookham. In the spring of $\mathrm{IS67}$, another example was killed on the banks of the Thames near Surley: I examined this bird, and the man to whom it belonged gravely informed me that it was a Godwit! The Rev. H. Crewe wrote me word that the Green Sandpiper is observed to frequent the reservoirs and canals near Drayton Beauchamp in small parties every winter. 
And a bird of this species, in the collection of the Rev. B. Burgess, was shot many years ago in the neighbourhood of Risborough.

When flushed at a brookside, the Green Sandpiper utters a shrill note, and generally follows the windings of the stream, flying at no great height above the surface of the water. It may always be recognised on the wing by its white upper tail-coverts, the spotlessness of which contrasts strongly with the dark greenish colour of the back and wings.

GREenshank (Totamus glottis). An uncommon species, although occasionally obtained during the spring and autumn months, when, like many others of the Totanide, it performs its usual migration.

It is sometimes, though rarely, observed on the banks of the Thames; and I have heard of some specimens which were obtained near Windsor, and preserved by one of our local birdstuffers. The Rev. B. Burgess, of Latimer, near Chesham, has a Greenshank in his collection which was shot in his neighbourhood many years ago. Yarrell states that Mr. Jesse forwarded him a note of one of these birds which was killed on Ascot Heath, not far from the house of Mr. Davis, the well-known hunter of Her Majesty's stag-hounds.

Dunlin (Tringa variabilis). During the spring and autumn the Dunlin is a passing visitant to the banks of the Thames; where, however, it is never very common. It is locally called the Summer Snipe, 
I46 THE BIRDS OF BERKS AND BUCKS.

a name which is also bestowed upon the Common Sandpiper. The Rev. H. H. Crewe states that small flocks of Dunlins frequent the Wilstone and Marsworth reservoirs every year during the early spring, and a few are again observed in the autumn. The Windsor bird-stuffers occasionally receive specimens for preservation which have been obtained in the neighbourhood. The Rev. George Jeans records in the Naturalist that he has shot the Dunlin near Windsor and at various places along the banks of the Thames. 


\section{ORDER V.-NATATORES.}

\section{Family-LARIDA.}

COMmon Tern (Stemahinundo). There is perhaps scarcely a more graceful bird on the wing than the Tern, or Sea Swallow as it is called; and it is a pleasing sight to watch a party of these birds on a calm day hovering over the receding waves, and anon darting down to secure their slippery prey for their young further up on the beach.

This species, like the Arctic, Black, and Lesser Terns, is a passing visitor in spring and autumn, though individuals are occasionally seen during the winter months. A common Tern was killed by Mr. Hall, of Windsor, in the month of November, I 865, as it was skimming over the Thames near Boveney Locks. Specimens have been obtained at Amersham; and Mr. Burgess informs me that it has been met with near Slapton. In the autumn of the year I 848, Mr. H. Daly killed one of these birds in a field near Eton, called the 'Brocas.' Another was shot by Mr. Howard, in I $85 \mathrm{I}$, at a place called Lakeend, not far from Burnham. This Tern is occasionally

L 2 
observed flying over the rescrvoirs at Drayton Beauchamp at the time of its migration. Several others have come under my notice which have been procured in this neighbourhood in autumn, but the exact dates of their occurrence could not be ascertained. An immature Common Tern, in the collection of $\mathrm{Mr}$. Sharpe, was shot a few years since at Cookham. Another, in the possession of Mr. Mills of Bisham, was killed near that place by himself. Mr. Gould told me that while on the river near Maidenhead, towards the end of May, I866, he shot a common Tern together with an Arctic and Black Tern, all of which are now preserved in the collection of $\mathrm{Mr}$. Grefell, at Taplow Court. Mr. Dalziel Mackenzie wrote me word that this bird has becn observed flying over the Thames near Pangbourne.

ARCTIC TERN (Stema aretica). This species had long been confounded with the Common Tern, which it closely resembles, but the distinctive characters of both have been pointed out by Mr. Temminck (Man. d'Ornith.), and more recently and clcarly by $\mathrm{Mr}$. Harting, in his 'Birds of Middlesex.' It is occasionally obtained in the countics of Buckinghamshire and Berkshire during the periodical migrations in spring and autumn, but it is never at any time numerous. The Arctic Tern is occasionally seen at the Marsworth and Wilstone rescrvoirs, and at other large sheets of water in the two countics. Many years ago Mr. H. Daly shot one of these birds in autumn, 
near Eton; and in November, 1865, an Arctic Tern was obtained at Boveney Locks. I have seen several preserved specimens which had been killed at various times in the immediate neighbourhood of Windsor. Towards the end of May, I866, Mr. Gould killed one near Maidenhead, * which he afterwards preserved.

Lesser Tern (Sterna minuta). Local name, Little Sea Swallow. This Tern is a summer visitor to England, and has on several occasions been shot on the Thames in spring and autumn. It does not appear to be at all an uncommon bird, and the following is a summary of the more recent instances of its occurrence in these counties, so far as I have been able to ascertain.

One was killed while flying about the canal at Slapton, in May, I850, as I was told, by the Rev. Bryant Burgess, of Latimer, near Chesham. In the month of July, I867, I examined a bird of this species which had been shot a few days previously on the river near Windsor. Others occurred about ten years since near the same place, and I have seen several more which have been procured in the vicinity of Eton at different times. Mr. R. B. Sharpe informed me that an immature specimen of the Lesser Tern was presented to him, which had been shot at Cookham Grove a few years ago.

BLACK TERN (Stema nigra). Local name, Black 
Sca Srvallow. This handsome Tern is not such an uncommon bird as is usually supposed, and is a visitant here in spring and autumn, while on its way to and from its brecding stations.

The Rev. Bryant Burgess, of Chesham, informed me that a Black Tern was taken at Risborough not long since; and the Rev. George Jeans says that he has seen this species at Windsor. He records in the Naturalist, vol. ii. p. 75, that a shoemaker named Wrigginton, shot onc of these Terns at Eton in I 825 , and had it prescrved there.

In the spring of $\mathrm{I} 847$, a good specimen of this bird was shot by an Eton birdstuffer named Fisher, while it was flying over the Thames between Surley Hall and Eton Wick. A few years since, in autumn, during the prevalence of an equinoctial gale, Mr. Drye, of Eton, shot a young bird of this species on the river near Windsor; and he has in his collection another, an adult bird, which was procured in the same neighbourhood some years later. A male Black Tern was killed by Mr. George Lillywhite, of Eton Wick, in the last week of September, I866, as it was flying along the banks of the Thames just above Surley; and an Eton taxidermist, named Hall, informed me that he had received several of these birds for prescrvation, most of which had been procured in the spring.

The Black Tern has occasionally been observed near Maidenhead and Datchet. Towards the end of May, 


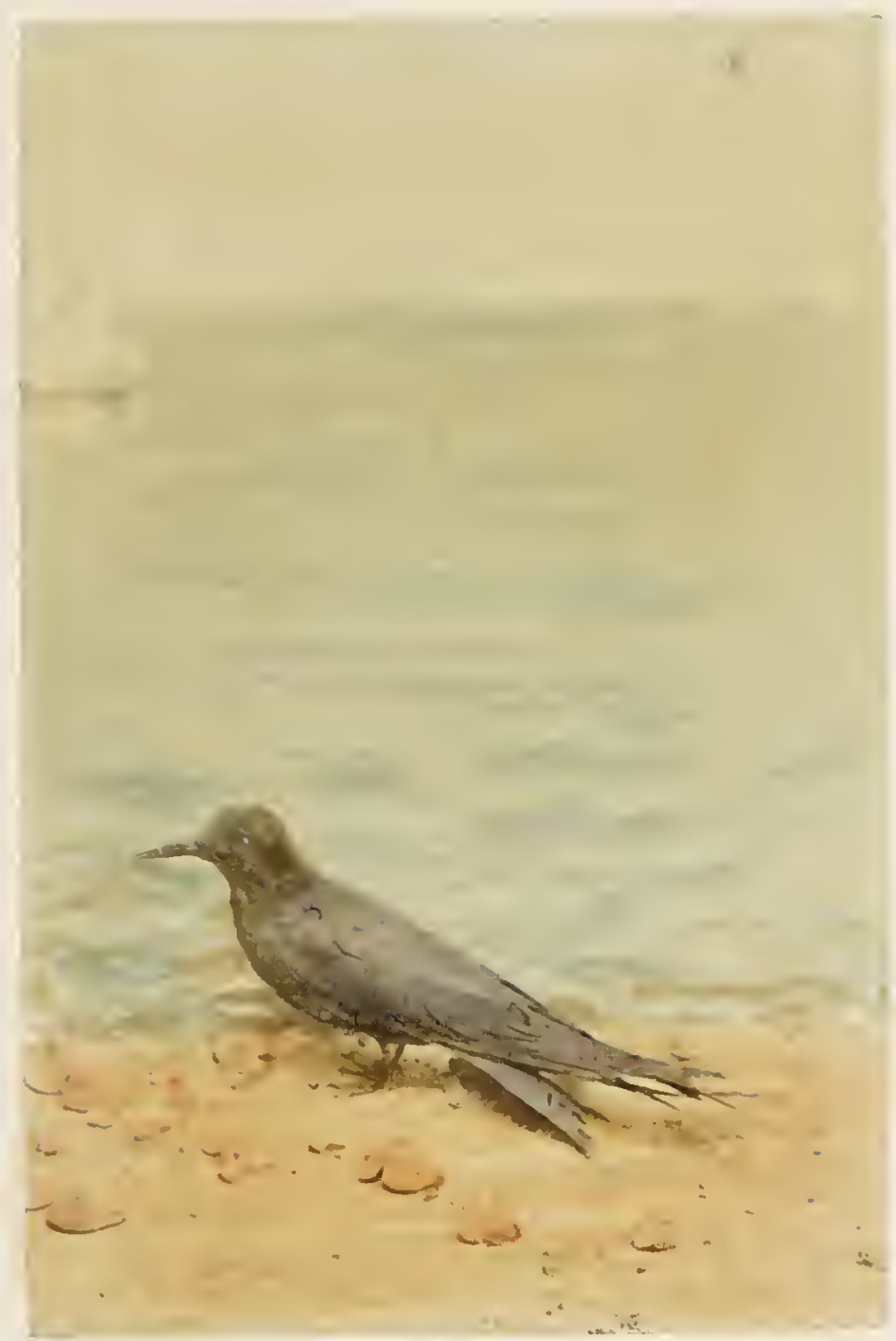

THE BLACK TERN.

Sterma migna. 

I 866, five Terns were seen by Mr. Briggs, of Cookham, flying about the river Thames, near Woburn, and two of these were shot, and are now in the collection of Mr. R. B. Sharpe. They proved to be a male and female of the Black Tern, and the ovary of the latter contained minute eggs. Mr. Gould happened to be on the river, near Maidenhead, the same afternoon, and killed the three remaining birds; which, as he told me, were curiously enough, all of different species, the Common, Arctic, and Black Terns. These are now in the possession of Mr. Grefell, of Taplow Court, to whom Mr. Gould presented them.

BlaCK-HEAdED Gull (Lanus ridibundus). A bird of this species in the fully adult plumage, is surely one of the prettiest of the Larida. For the last four years I have observed small parties of them on the Thames in spring, and a few are again observed in autumn on their return from their breeding grounds. I have seen several preserved specimens which had been shot in both counties. This Gull, more than any others of the genus, appears to prefer the neighbourhood of fresh water. The Rev. Bryant Burgess wrote me word that the Black-headed Gull had been taken near Chesham, in summer plumage. It has also occurred on the reservoirs near Drayton Beauchamp, and in a few other places where an abundance of water offered a tempting resting-place.

Kittiwake Gull (Larus tridactylus). In Buckinghamshire and Berkshire the Kittiwake is not a 
common Gull, but a few specimens are occasionally obtained in spring and autumn. In March, r \$67, I saw one of these birds flying over the river near Datchet. Mr. Drye, of Eton, possesses one which was liilled in that neighbourhood in I $865^{\circ}$; he tells me that since his residence in Eton he has had several Kittiwakes sent to him for preservation, and that the majority of these were procured after equinoctial gales. I have examined some half a dozen of these Gulls preserved in various local collections, but have been unable to obtain any particulars respecting them. My friend Mr. Sharpe informed me that the Kittiwake had occurred at Cookham; and specimens have been procured near Chesham. Small flocks are occasionally seen near Fawley and Pangbourne.

Common Gull (Lams canus). As its name implies, this Gull is pretty generally distributed along our coasts, but seldom ventures far inland, except in severe weather, or during the period of migration in spring and autumn.

The Common Gull has been taken at Chesham, and I have seen it flying over the Thames in autumn, at which season specimens are occasionally shot near Windsor. Mr. Wolley tells me that he observed a flock of five of these birds near Chalvey in I 863. One was killed in the neighbourhood of Fawley, by $\mathrm{Mr}$. Mackenzie's game-keeper in I863. Mr. James Britten, the Honorary Secretary to the Natural History 
Society of High Wycombe, informed me that a Common Gull was seen, in I867, in Wycombe Rye; shortly afterwards one, believed to be the same, was killed in Buckinghamshire, near Uxbridge.

“ 『lye propex organs, proper potorex assigned; (extry seeming buart compensatco of course,

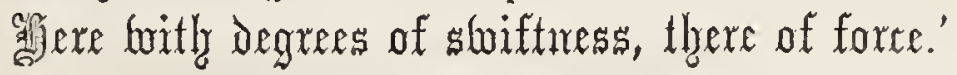

POPE.

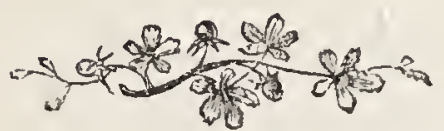




\title{
RARE AND ACCIDENTAL VISITORS.
}

\author{
- \\ ORder I.-R A P T O R E S.
}

Family-FALCONIDN.

Golden Eagle (Aquila clirysactos). The Golden Eagle seldom wanders far from its mountain home, and is consequently one of the rarest visitors to Buckinghamshire and Berkshire.

In 1847 an Eagle of this species was shot by a keeper at Littlecot, the seat of Mr. Popham, near Hungerford, in Berkshire: "It had glutted itself on a dead deer, and was unable to fly away upon the approach of the keeper, who fired six times before he killed it.'* Mr. Buckland, in his 'Curiosities of Natural History,' states that 'Three or four years ago a Golden Eagle was shot in the forest at Windsor, and presented by His Royal Highness the Prince Consort to Eton College;' but it is probable that Mr. Buckland refers to a fine White-tailed Eagle which was shot in $185 \mathrm{I}$, and presented to the College by the late Prince.

* Morris's 'British Birds,' vol. i. 
My friend Mr. R. B. Sharpe informed me that Mr. Briggs, of Cookham, once observed the Golden Eagle at Billing Bear, where he was formerly employed as a keeper. He was walking with another keeper near the outskirts of a plantation, adjoining a field in which some pheasants were feeding. Suddenly there was great excitement among the birds, and several flew quickly into the woods. But before they could all reach a place of safety a large Eagle flew swiftly down, and carried off a pheasant in his talons. Mr. Briggs' fellow-keeper immediately set a trap near the spot, and within three days had the luck to secure the robber, who proved to be, as they had suspected, a Golden Eagle.

White-Tailed Eagle (Haliaectus Albicilla). A White-tailed Eagle was shot near Windsor upon the 3d of February, I85 I. This specimen was preserved by Mr. H. D. Bartlett, of College Street, Camden Town, Middlesex; and it was exhibited in its case by him in the Great Exhibition of I 85 I.

It was afterwards presented by His Royal Highness the late Prince Consort to the collection which was principally formed by the late Provost at Eton College. Yarrell records that one of these rare Eagles was taken at Fawley Court, in Buckinghamshire, since the first edition of his work was published.

A fine Eagle of this species was procured in Berkshire in 1856.

' On the afternoon of the 12 th of December in that 
year, as one of the officers of the garrison of Windsor was riding in the Great Park, not far from the statue of King George III. at the end of the Long Walk, he was surprised to see a large bird on the ground, gorging himself with a rabbit. He advanced towards it, but the bird flew up into a tree. When on the tree it appeared to have a chain round its les, but this was afterwards ascertained to be a portion of the rabbit it had just been eating. The pursuer having clearly made out that this large bird was an Eagle, a most unusual visitor to the royal forest, rode off immediately to the keeper's lodge with the news. The keeper, while mounting his pony, stated that the bird had been seen about the forest for four or five days, but had always kept out of shot. When they both got back to the place where the bird was sitting, the kccper concealed himself and his gun, while the officer rode round the bird endeavouring to drive him over the ambush. Off he went at last, but flew wide of the keeper. Then came the riding part of the business partaking more of the character of a steeple-chase than of hunting. By dint of hard and difficult galloping, among rabbit-holes, thick ferns, and open drains, the Eagle was again marked down in a clump of trees. Then followed a little stalking. The keeper on his pony and his companion on his horse advanced carefully, but the cunning bird would not allow them to come near. The keeper then got off his pony, and walked alongside the horse, which was of a grey colour, 
and seemed not to alarm the bird so much as the pony which was of a dark colour.

- After a few steps the keeper suddenly and quietly glided behind a tree, and the grey horse and his rider advanced farther. To divert the attention of the suspicious bird the latter wisely made as much noise as he could, tapping the saddle with his whip, riding among the thick ferns, and pretending all the careless unconcern he could assume. In the meantime the keeper got near, and fired both barrels. The bird flew away, but had been evidently hard hit, for his flight was laboured and near the ground. He alighted at last on the bough of a young tree, where his drooping wings and fainting form made him look more like an old coat hung up as a scarecrow than an Eagle.

'Both the pursuers then rode up, and again, although wounded and bleeding, the courageous bird started off, but he could not go far ; it was his last flight; for in another minute he dropped dead, shot through the right eye. The former shot had hit him in the body, but had in no way damaged his plumage. Shortly afterwards we inspected this noble bird, and found him to be a fine specimen of the White-tailed Sea Eagle. He measured with outspread wings eight feet; the length of his body from his beak to his tail was three feet two inches; and he weighed twenty-two pounds. From his plumage, which was in excellent condition, it seemed probable that he was a wild bird; there being no marks either of cage or 
chain to indicate that he had ever been in captivity. His skin has been well preserved in a well-chosen attitude.'*

Another Cinereous Eagle in immature plumage was shot by one of the royal keepers in Windsor Great Park in the summer of 1865.

About the same time, another bird of this species was seen by the keepers about the park. It was slightly wounded and captured, and is alive at the present time (IS67), under the care of Mr. Cole at the Sandpit Gate in the park.

Osprey (Pandion haliaetus). Local name, Fishhawk. Like the last-named, an accidental visitant. The Rev. F. O. Morris records the appearance of this species at Donnington, in Berkshire; and it has been observed also at Pangbourne in the same county more than once.

In February, I845, an Osprey was killed at Chequers, in Buckinghamshire. This bird is now in the collection of Lady Frankland Russell.

I am indebted to Mr. Crewe for the notice of a third specimen of the Osprey, which was obtaincd on the banks of the canal at Halton, during the year I854. It was shot by a labouring man whilst devouring a dead pigeon which had been thrown on to the towing-path from a neighbouring dovecot. This bird is in the possession of Sir Anthony de Rothschild, Bart., of Aston-Clinton.

* Buckland's 'Curiosities of Natural History,' vol. i. 
Mr. Dalziel Mackenzie has informed me that an Osprey was shot in the Livedon Woods, in the parish of Hambledon, during the winter of 1858 . It was seen in the a djoining Fawley Woods for several days previously.

In I 864, as I learnt from Mr. Hasell, of Windsor, an Osprey was shot by a keeper named Deane, in Windsor Great Park.

Some time since, Lord Henry Scott informed me that there was a stuffed Osprey in the hall at Ditton Park, Buckinghamshire. Upon going over to the Park to see it, I learnt the following particulars concerning it. On the 26th of September, I863, the lodge-keeper saw a large bird flying over the park at an immense altitude. On returning to the spot with his gun, which was loaded with No. 2 shot, he saw the bird settle upon the ground near a tree; he approached carefully in hope of getting a shot, but making some slight noise, the wary bird made off, and recommencing its aërial evolutions, again ascended to a great height. He watched it for nearly an hour, until he marked it down again by a clump of trees, some way off; it was now growing dusk, but the keeper, being anxious to obtain the bird, made for the place where he had last seen it settle. He approached carefully, and this time was more fortunate, for as the Osprey rose the cruel shot rattled against his feathers, and 'stretched him almost lifeless on the sward.' He was soon despatched, and the lucky 
captor made off with his prize, which measured, with wings extended, five feet four inches.

The bird had been seen for some days previously hawking for fish over the Thames, near the Victoria Bridge, and at Willowbrooke. Though several persons endcavoured to kill it, it always flew at too great a height, and was exceedingly wary. It was stuffed by Fisher of Eton, who found the maw distended with freshly-caught fish.

The Rev. H. Harpur Crewe wrote me word that, during the greater part of September, IS64, a pair of Ospreys frequented the large reservoirs of the Paddington Canal Company, which are situated in the parish of Wilstone, and hamlet of Tring, Hertfordshire, and also in the adjoining parishes of Weston Turville and Marsworth, Buckinghamshire. They were exceedingly tame, and used to take fish from the reservoirs and canals whilst persons were standing close by, and looking at their proceedings. It would have been well had these poor birds been permitted to remain in peace, for even the gamekeepers did not molest them; but, I regret to say, their fearless and sociable habits at length proved fatal to them. On September 3oth the female bird was killed, whilst fishing in the canal at Wilstone, by a country lad. After some trouble, Mr. Crewe succeeded in obtaining possession of the skin, which he preserved, and it is still in his collection at Drayton Beauchamp. It was a young bird of the previous 
year. The male bird left the neighbourhood after the female was killed; but as a male Osprey was shot on the river at Maidenhead a few days afterwards, it was most probably the same bird.

My friend Mr. Sharpe sent me word that an Osprey was killed at Cookham, in October, I864. Mr. Briggs observed the bird flying slowly along over Lord Boston's woods, and while intent upon watching it, it sailed over to the place where he was standing, and circled around him at the height of about thirty yards. He called to a man who was near him to fetch his gun; but by the time it arrived the bird was out of shot, and was pursuing its course down the Thames with graceful flight. A gentleman, who happened to be out on the river with a gun, observed the Osprey approaching, and as soon as it was near enough, fired, and winged it. It fell into the water, and was then despatched by a blow from a boat-mop. For several days previously a large hawk (probably. this Osprey) had frequented the Hedsor woods, and three days afterwards another Osprey was seen near the same spot by a person named Stanniforth, the lock-keeper at Cookham.

During the years I865, I866, I 867, and the early part of 1868 , an Osprey was frequently observed near Surley Hall, and although many attempts were made to shoot it, it fortunately contrived to escape.

A man, who had several times seen this bird hovering over the water in search of fish, told me that 
'he opined the hawk was a-looking fur his own shadder!' This Osprey was observed to capture fish at all times of the day, and after taking one it would fly off to a lofty trec on the river bank to digest its meal.

Peregrine Falcox (Falco pergorimus). This noble Falcon has almost entirely disappeared from localitics where formerly it was not uncommon, and can now only be regarded as an occasional winter visitant. On the Ist of August, I 846. Mr. Bryant Burgess, of Latimer, saw a fine Peregrine which had becn slot in Liscombe Park. It was in the possession of Mr. Bishop. In the year I853, a young female Pcregrine was captured in a trap in Windsor Great Park, and was taken to Mr. Hascll, of Windsor, who prescrved it. Mr. Frank Collins, of Betterton, writes me word that this falcon is occasionally observed soaring over the downs and woods near Wantage. A beautiful specimen was killed by Mr. Collins, of Goosay, in that neighbourhood. A pair have becn on several occasions scen at Wooley Park, the scat of Mr. P. Wroughton. Mr. James britten, of the High Wycombe Natural History Socicty, informed me of one of these birds which had been recently captured in Brickhill Wood, near Woburn.

RED-FOOTED FALCON (Falco rufpes). The Inspector of the Eton police-forcc-a12 intelligent man, who has a taste for natural history-informed me that an Orange-legged Hobby was shot by the under- 
keeper on Sir Henry Vernon's estate at Steeple Claydon, near Buckingham, in January, 1858.

The date was an unusual one at which to find this species here, but my informant is acquainted with the bird, and is not likely to have been mistaken.

KITE (Miluns vulgaris). The Forked-tailed Kite, once a common bird in Great Britain, is now scarcely ever seen in its old haunts, and every instance of its occurrence here is now of great interest to the ornithologist.

My friend Mr. R. B. Sharpe has written me word that although no recent occurrence of the Kite in these counties has come under his notice, the species was nevertheless common within the memory of persons still living at Pinkney's Green, an unenclosed heathy tract about four miles distant from Cookham. The Rev. Mr. Crewe informed me that a Kite was killed several years ago at the reservoir near Drayton Beauchamp, by Mr. S. W. Jenney. This specimen is in the possession of Sir John Harpur Crewe, of Calne Abbey, in Derbyshire.

The Rev. Murray A. Mathew, of Weston-superMare, wrote me word that about the year I 855 a fine Kite was shot at Abingdon, which is now in his collection. 'Poor old Osman, the birdstuffer, of St. Aldates, Oxford,' adds Mr. Mathew, 'has often told me that when he was young the Kite was quite a common bird in Oxfordshire and Berkshire, and might be seen any day by persons taking a country walk; indeed 
it used often to be observed gracefully sailing in the air over the very Oxford strects.' Mr. Wolley told me that while out for a stroll one day many years ago in the fields near Eton, a Kite flew over his head, and so low as to enable him to determine casily the species by its forked tail.

Common Buzzard (Butco onlgaris). A Common Buzzard was shot in Windsor Great Park by one of the keepers in the summer of I 857 . Another specimen was procured there about the same time, but by the time it reached the birdstuffer's hands it was useless. These two birds had been seen about for some time together, and were probably a pair.

In I 830 and $S_{3}$ I a tame female Buzzard, kept at Uxbridge, in a garden of the 'Chequers' Inn, showed a strong inclination to sit, by collecting sticks, \&c.; her owner then supplied her with the necessary materials for forming a nest: she sat on and hatched two chicken's eggs; and since then she has brought up chickens every year:*

A fine male of the Common Buzzard was shot at Hollyport in I862, and was sent to Mr. Briggs of Cookham for preservation. The way in which it was captured was curious:-A man named Wells was trying to shoot some Wood I'igeons, and had placed upon the ground a stuffed bird as a decoy. He had not waited long before the above-mentioned Buzzard swept down, and was carrying off the stuffed 
pigeon, when he shot it. Mr. Gould states that the finest pair of Buzzards he ever saw are now living at Berry Hill, the seat of John Noble, Esq., at Taplow; but whether these birds were obtained in these countics or not, I do not know. In December, I866, a fine male Buzzard was liilled by $\mathrm{Mr}$ Alfred Wellbeloved, in a wood near Sunninghill The crop of this bird contained the remains of a great many small birds.

Rough-LegGed Buzzard (Buteo lagopus). A rarer bird than the Common Buzzard, which it resembles in its habits. It is usually obtained either in the spring or autumn, when migrating from north to south, or vice acrsid. The flight is like that of the common species, and its prey consists of reptiles, rabbits, and small birds. I am indebted to the Rev. B. Burgess for a notice of a pair of Rough-legged Buzzards which were shot in Bledlow Woods, Buckinghamshire, in the month of November, is39. The female of this pair is in Mr. Burgess's collection.

Honey Buzzard (Pernis apivonus). As remarked by Meÿer,* "Selby describes one which appears to be a male approaching the plumage of the adult, as it had the head brown, inclining to ash-colour; and Montagu's specinen, which was shot in Berkshire, and since placed in the British Museum, is supposed by Mr. Selby to be a female, or young bird, having the under parts of the plumage brown.' The Berkshire * 'British Birds,' vol. i. p. 86. 
specimen was killed at Highclare, the seat of the Earl of Canarvon.

I am indebted to the Rev. Bryant Burgess for the notice of a Honey Buzzard which was captured in 1842, between Chesham and Missenden. A fine Honcy Buzzard was trapped in Windsor Forest by a kecper in the year I860. It was prescrved by Mr. Hasell of Windsor, at whose house I saw it some time since.

Montagu's Harrier (Circus Montagur). A rare species, named in honour of Colonel Montagu, who first described the bird as the Ash-coloured Harrier. The Rev. Harpur Crewe informed me that a specimen of this bird was killed some years since by Mr. A. H. Jenney, in the parish of Drayton Beauchamp, in Buckinghamshire. It is now in the possession of Sir J. H. Crewe. Mr. R. B. Sharpe sent me word that a Harrier of this species was procured by a sentleman of his acquaintance near Eton in the summer of $\mathrm{I} 867$, and is now in his collection.

\section{Family-STRIGID E.}

Scops-EARED Owl (Scops Aldrovandi). Mr. Morris states that a Scops-eared Owl was shot near Brill, in Buckinghamshire, in the year 1833 . In 1858 or I 859 , a second specimen was found dead inside a rotten turnip, which was lying in a field just above Kingston Lisle Park, the seat of Mr. Martin Atkins. The cause of its death can only be con- 
jectured, for a more extraordinary tomb could hardly have been selected. The skin was fortunately preserved, and Mr. A. Collins, to whom I have previously referred, assured me that he saw it stuffed at a birdfancier's shop in Wantage.

Tengmalis's Owl (Noctua Tengmalmi). Mr. Hasell, the bird-stuffer of Windsor, had a female Owl of this species brought to him to be preserved in the summer of i 864. It was shot in Windsor Forest by one of the gamekeepers. Another was killed a few years previously in the same park, and was also preserved. Mr. Hasell is well acquainted with the species, and the above statement may be depended upon.

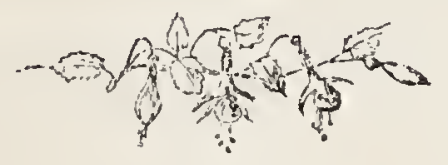




\section{ORDER II.-INSESSORES.}

Tribe-Dextrirostres. Fomily-Laniade.

Great Grey SinRIKE (Lanius crabitor). This species might have been included amongst the winter visitants, as scarcely a scason elapses in which it is not observed, but since its appearance is not marked by sufficient regularity, I have preferred to place it amongst the Accidental Visitants. The Rev. H. H. Crewe wrote me word that a male Great Grey Shrike had been shot on the 4th of November, 1854, at Weston Turville in Buckinghamshire. This bird was brought to him in the flesh. On the $\mathrm{I}$ th of the same month a femalc of this species was likewise brought to him, which had been shot near Wendover, Bucks, about a week previously.

Mr. Hasell, of Bexley Strect, Windsor, informed me that a fine Grey Shrike, which I have since seen, was shot in Berkshire about fiftecn years ago. The name of the exact locality whence it was obtained, he had forgotten. Another example of this Shrike was killed by a person named Taylor on the banks of the Thames, at Clewer, in the winter of $1859-60$. 
In I862, a fine male was shot by a son of the Rev. M. Gore, near the Almshouses at Stoke. Some time since, while looking over a collection of birds shot by Mr. G. Lillywhite, of Eton Wick, Buckinghamshire, I was agreeably surprised to see a fine example of the Great Grey Shrike. It was shot by Mr. Lillywhite on the banks of the Thames, not far from Windsor, in the winter of $1865-66$, and was stuffed by Mr. Drye, of Eton.

Another, in the collection of the Rev. Bryant Burgess, was killed a few years since at Hampden. A Great Grey Shrike was shot at Hedsor, near Cookham, in the autumn of 1867 , and Mr. Briggs has noted its occurrence in several instances at Billing Bear, which is about ten miles from Cookham.

\section{Family-Muscicapida.}

Pied Fly-Catcher (Muscicapa atricapilla). An extremely rare visitor to these counties.

Mr. Morris records that a Pied Fly-catcher was killed many years ago within the county of Buckinghamshire, but not far from Uxbridge. A second was procured in Berkshire about ten years since, and was taken to Windsor to be preserved. My friend Captain Henry Elwes, of the Scots Fusilier Guards, informed me that a well-authenticated nest, containing eggs, of this rare species, was taken near Eton in. the summer of i 860 . 
Family-Meruidis.

Common Dipper (Cinclus aquaticus). Although the Water-Ouzel, or Dipper, is a common bird in Scotland and in the north and west of England, it can only be considered an accidental straggler to the countics of Berks and Bucks.

Mr. Yarrell states that he heard of a Dipper being killed at a water-mill tail, on the Colne, near Wraysbury (or Wyrardisbury), which is on the borders of Buclinghamshire. In his 'Birds of Great Britain' Mr. Gould states that he knew of one cxample which was obtained on the little Buckinghamshire river the Chess. My friend the Rev. Harpur Crewe wrote me word that he once observed a solitary Dipper on the canal at Drayton Bcauchamp. He saw it fly out from under a bridge, and was sufficiently near to determine the species with certainty.

Golden Oriole (Oriolns galbula). A rare summer visitor. My friend Mr. R. B. Sharpe informed me that a bird of this specics was once observed at Billing-Bear by Mr. Briggs. He was out walking one day when his attention was attracted by the note of a bird which he felt convinced he had never heard before. Following the direction of the sound, he traced it to a dense thicket of young ash-trees, and after having cautiously entered, he managed, by dint of crawling slowly along, to get within twenty yards of the bird. On a branch just above his head 
sat a beautiful Golden Oriole, and he had an opportunity of watching it for two or three minutes, until it at last caught sight of him and flew away.

A nest of this bird is said to have been found near Burnham ; but a supposed Golden Oriole's nest, containing eggs, which was taken near Slough a few years ago and purchased by the Rev. C. Wolley, turned out to be that of a Thrush, with the eggs of a white ground colour instead of blue, and having the usual black spots.

\section{Family-Sylviadæ.}

Black Redstart (Phonicura Tithys).* The Black Redstart may be considered a rare winter visitant in England, and, so far as I am aware, its claim to a place in this catalogue rests upon a single instance of its occurrence in Berkshire.

In a letter to me, dated 2 Ist of November, I867, my friend Mr. R. B. Sharpe, to whom I am indebted for many ornithological notes from his neighbourhood, says: 'I am able to give you an undoubted instance of the occurrence of the Black Redstart at Cookham. Mr. Briggs, the head-gardener at Formosa, whose name I have before mentioned to you, and from whom I have received so much interesting information, tells me that in the year I86r he was

* The Black Redstart is also known by the names of Blackstart, Black Redtail (Jenyns, 'British Vert. An.' p. I05), and Tithys Redstart (Selby, 'Brit. Ornith.' vol. i. p. 193). 
out shooting Redwings in company with a man named Stanniforth, who had charge of Cookham Lock at the time, and he was much surprised to see what he thought to be a female of the Common Redstart sitting on a post. It was snowing hard at the time, and he drew Stanniforth's attention to the singular fact. On mentioning the circumstance to Mr. Gould shortly after, that gentleman told him that it must have been a Black Redstart, as this species only visits us in winter, when the Common Redstart has cntirely left us. Mr. Briggs says the bird seemed a little darker than the females he had before seen, but he attributed this to the dusky appearance which the state of the weather would naturally give the bird. For further information respecting the Black Redstart I must refer you to Mr. Gould's "Birds of Great Britain," where the subject is thoroughly treated of.'

SArI's WARbLER (Salicaria luscinoides). The notices of the occurrence of this rare Warbler in England are few and far between. The species is included in this catalogue upon the authority of Lord Clifton, who published the following note in the Zoologist for April, i 867: 'Last Junc ( I 866), in the neighbourhood of Eton, I saw a bird which I am pretty sure was Savi's Warbler: it was in a low hedge which I am in the habit of passing nearly every morning, and the favourite resort of Sedge Warblers, close to the river Thames: having heard a harsh 
note, like that of the Sedge Warbler, I looked for the bird, and got a fair sight of it for a moment while sitting on the top of the hedge, when I discovered it was no common Warbler, but a bird with a reddish-brown back, with (I think) a black line across the wings: the cheeks and breast were greyish white. I thought it would prove to be Savi's Warbler, but I had no idea how closely Morris's plate would describe my bird.' * I am rather uncertain about this being the real Savi's Warbler, but I give the statement for what it is worth.

Fire-CRESTED ReGUlus (Regulus ignacapillus). A rare visitor; but doubtless often considered to be commoner than is really the case, for many persons suppose that the only distinguishing point between the Gold-crest and the Fire-crest consists in the latter having a brighter crest. Were this so, mistakes would be endless. The three lines which are conspicuous on the cheeks of the Fire-crest are in the Gold-crest absent. About three years since, two Fire-crests were procured near Eton; and Mr Hasell told me that he had had the nest and young of the Fire-crested Wren, together with the old birds, brought to him in 1863 . The nest was built in a yew-tree, nine feet from the ground, close to Frogmore House in Windsor Park.

* Mr. Harting kindly supplied me with the following note:- The note is not at all like that of the Sedge Warbler, but more like that of the Grasshopper Warbler. It can scarcely be said to have a reddishbrown back, the colour being the same as that of the Reed Wren, and there is no blacl: line across the wings.' 
Family-Calamopimime.

BEARded REEDLing (Calamophilus biamicusLEACH). As this species appears to be so distinct from all the Paride, I have preferred to call it the Bearded Reedling, and place it in the family Calamophilide. In Yarrell's time the Bearded Reedling had been found on the banks of the Thames from London upwards, as far as Oxford. I believe it is more numerous along the reedy banks of the river than is generally thought to be the case. Mr. Williams, of Tring Park, shot a pair of these birds some years ago on the banks of one of the reservoirs at Drayton Beauchamp, as I was informed by the Rev. H. Harpur Crewe.

\section{Family-Ampelid}

Boheman Waxwing (Bombycilla garrula). A beautiful but accidental straggler to Britain, usually making its appearance in the winter season. An immense flock appeared along the eastern shores of our island in the winter of $1849-50$, which was very severe, and several specimens were at that time procured in different parishes in Buckinghamshire.

I am indebted to the Rev. Bryant Burgess for the notice of a Bohemian Waxwing which was killed at Ivinghoe Aston, in January, I 850 , and which is now in his collection. An immense number of Bohemian 
Waxwings were shot in the neighbourhood of Buckingham during the spring of I867, as $\mathrm{Mr}$. J. W. Thorpe told me.

\section{Tribe-Conirostres. Family-EMBERIZIDAi.}

Snow Bunting (Plectrophanes mivalis). During the winter months this pretty species is not uncommon in some parts of Scotland and in the northern counties of England, but few comparatively are observed in the more southern counties, except in severe weather, when straggling flocks at intervals make their appearance. As to its occurrence in Berkshire, I have again to thank Mr. R. B. Sharpe for a notice of one which was killed at Cookham.

Mr. Joseph Ford, of that village, who is a clever taxidermist, and takes a great interest in ornithology, gave him a skin of the Snow Bunting in winter plumage, which he had preserved; but he could not remember any particulars, except that the bird in question was procured by one of the shoemakers in Cookham. The skin is now in the collection of $\mathrm{Mr}$. Sharpc, who is quite satisfied of the authenticity of the species.

On the I4th of September, I866, an early date for this bird, I shot one of them close to the sea at Funstanton, in Norfolk. It was in that state of plumage intermediate betwcen the summer and winter dress, and was exceedingly fat. 
CiRL, Buntang (Embrianatus). In the year ISoo, Colonel Montagu added the Cirl Bunting to the British list, having discovered several in the winter of that year near Kingsbridge, in Devonshire.

The Rer. F. O. Morris states that in the summer of 1826 , or I $\$ 27$, he procured one in the grounds of East Garston Vicarage, near Lambourne, in Berkshire. He says that there were a pair, and that his attention was frrst directed to them by the peculiarity of their note, which was uttered from the top of an elm tree, and which struck him as being different from anything he had heard before, as there was a peculiar sharpness in it. He adds that he had the good fortune to cbtain their nest and two eggss.

Some unusually fine specimens of the Cirl Bunting, in the collection of Mr. Gould, were procured in the grounds of Formosa, near Cookham. The Rev. H. Harpur Crewe has informed me of the occurrence of this Bunting near Drayton Beauchamp. He states upon the 4th of June, I S64, whilst walking on a rough grassy down in the parish of Drayton Beauchamp, he flushed a hen Cirl Bunting from her nest in a wild juniper bush, which contained three eggs hard set, and which I believe are now in his collection. In the winter of $1862-3$, a pair of these birds were brought to him, which had just been caught alive in a sieve-trap at Pitstone, in Bucks. Mr. Crewe further assured me that he had observed the male bird on two other occasions during walks about his parish. 
A bird-catcher of that neighbourhood, by name Baldwin, informed Mr. Crewe that he occasionally caught birds of this species in his nets during the autumn and winter months, and obtained a ready sale for them in London.

I am not aware that the Cirl Bunting has ever been observed near Windsor, although I once heard upon very slight authority that a specimen had been procured in that neighbourhood.

My friend Mr. Sharpe tells me that the Cirl Bunting is not uncommon in the neighbourhood of Cookham, where specimens are procured almost every summer. One was shot at Risborough in the year I839, and Mr. Burgess informs me that he fully believes he has seen the Cirl Bunting near Amersham.

Ortolan Bunting (Emberiza hortulana). This bird, which in France and other parts of the Continent is held in much estimation for the table, is generally considered a rare and accidental visitor to Britain.

Mr. Sharpe informed me that a few years since three birds of this species were shot near Cookham by a man named Nott. These specimens were well identified, but they were unfortunately not preserved.

\section{Family-STURNIDÆ.}

Rose-coloured Pastor (Pastor roseus). An extremely rare straggler. It has generally been found associating with Starlings, in the company of cows 
and sheep, and it is from this fact, no doubt, that the bird has derived the name of Pastor, or shepherd.

Mr. Gould, in his fine work on the 'Birds of Europe,' states that a Rose-coloured Pastor was shot by his friend Mr. John Newman, at Iver Court, near Langley, in Buckinghamshire.

\section{Tribe-SCANSORES. Family-PICIDE.}

Great Black Woodpecker (Picus martius). In April, r844, a Great Black Woodpecker was seen on several consecutive days in the Home Park, Windsor. The observer in this case was a Mr. Walter, whose word I have no reason to doubt, and, moreover, he gave so accurate a description of the bird, as to leave no room for doubt that it was a veritable Picus martius. Improbable as it may appear to sceptical ornithologists, I feel further justified in including this species in the present catalogue from my own personal observation. In March, I867, while walking under some elms in Ditton Park, I saw a Great Black Woodpecker busily engaged on one of the tallest trees within a short distance of me. I was sufficiently near to identify the bird with certainty, and had an opportunity of observing its movements for the space of half a minute, when it flew off with an undulating flight to a considerable distance, and was seen no more. 


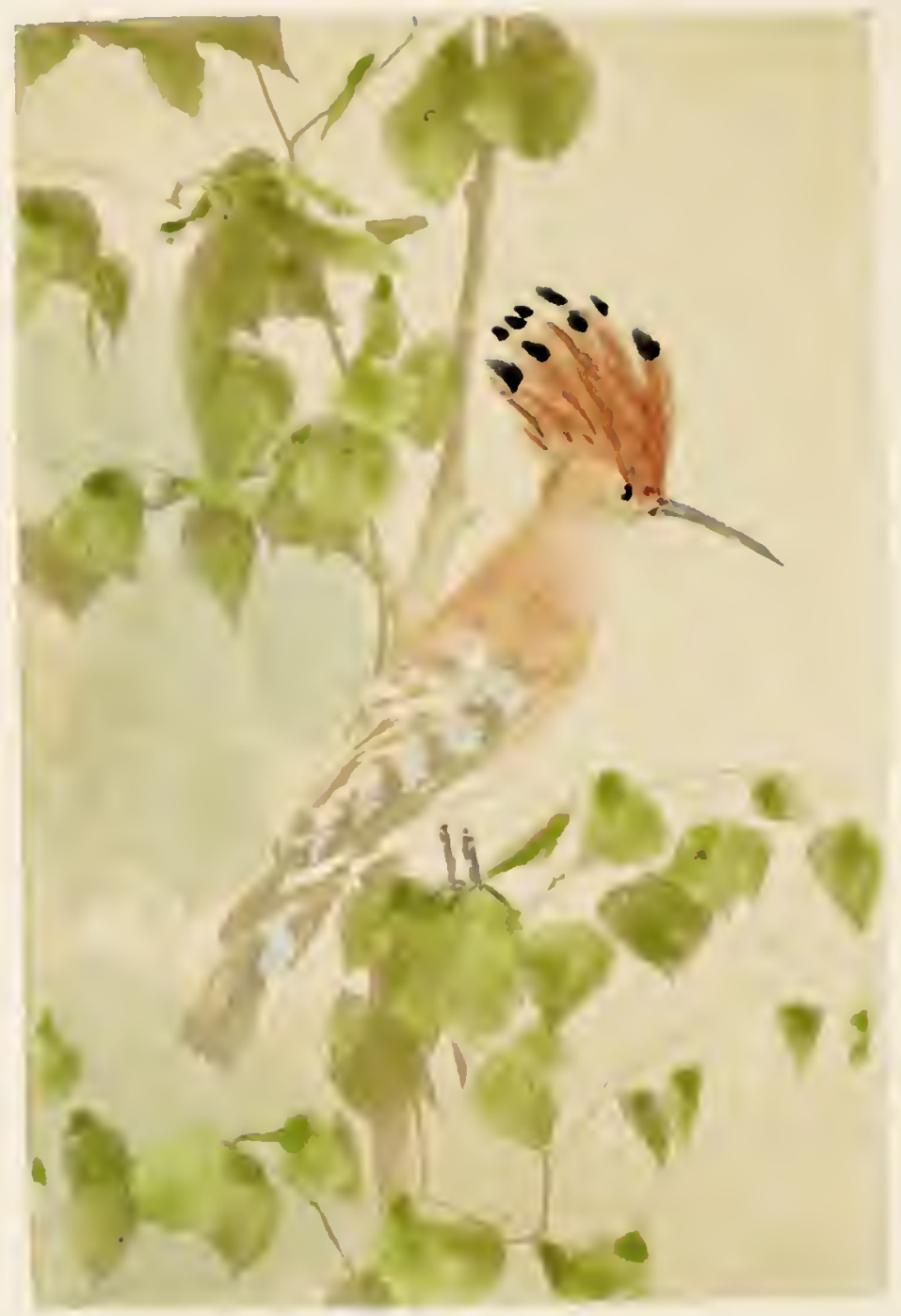

THE HOOPOE.

trupa epops. 


\section{Genus-UPUPA.}

HOOPOE (Upupa epops). This very curious bird has occasionally been killed in both counties. It is a summer visitor of uncertain and rare occurrence from warmer climes.

One was caught alive near Eton some six or seven years since, and became so tame that it would run up its master's legs and come at his call. This interesting bird was offered to the Zoological Society, but for unexplained reasons they did not take it. It died about two years afterwards. Mr. Gould told me of another which was shot by a man well known at that time as Shampoe Carter, in a large open field near the Eton Wick public-house; it was brought to him, and he says that it was one of the first birds he ever preserved: this was forty years ago. Mr. F. Layton killed a good plumaged bird in the autumn of I 864, in a brick-field opposite the Spital barracks, and he once observed a Hoopoe in Windsor Great Park. One was shot at Wallingford about the i8th of June, I867. This was a fine male bird, and was killed by Mr. J. P. Franklin, of Brook Cottage, Ewelme, near Wallingford, and was sent to London for preservation. Mr. R. B. Sharpe wrote me word of a sixth, which was obtained in the vicinity of Cookham a few years ago.

My friend Mr. Congreve informs me that another was killed close to Aldermaston, Berkshire, in the 
carly part of the present century. Another, which was shot at Lacey Green in the ysar 1838 , is in the collection of the Rev. B. Burgess. Mr. Burgess had told me of one which was killed at Aston Abbots in I85I. More recently, specimens have been captured near Chesham. A fine specimen of the Hoopoe was killed about two miles from Buckingham during I 867 , and is now in Mr. J. W. Thorpe's possession.

\section{Tribc-FissIROSTRES. Family-MEROPIDA.}

BEE-EATER (Mcrops Apiaster). I am glad to be able to include the handsome Bee-eater in the present catalogue, and I am indebted to Mr. R. B. Sharpe for the notice of its occurrence. I cannot do better than give an extract from his letter to me on the subject.

'In these days it is indeed hardly credible that such a rare and brightly-plumaged bird as the Beecater could have been allowed to proceed so far inland as Berkshire; how much more incredible, then, will it appear, when I tell you that one of these beautiful birds not only came so far, but actually lived for some time unmolested; yet Mr. Briggs informs me that Mr. Frost, head-gardener to the Hon. G. Fortescue, at Dropmore, informed him that a Bee-eater visited the gardens there in 1866 , and remained there some days. He would on no account allow the bird to be molested, and it used to sit on 
a bare twig, near a wasp's nest, whence it flew down and seized any insect which approached or left the nest. The bird was at last shot, having wandered from the neighbourhood of its kind protector.'

\section{Family-Hirundinidæ.}

Alpine Swift (Cypselus alpinus). But few examples of this rare Swift have been observed or taken in this country, and I am fortunate, therefore, in being able to include the species in the present catalogue.

I am informed by Mr. J. E. Harting, who has seen the bird, that in the month of August, I84I, a specimen of the White-bellied Swift was shot near Reading, Berks, and was obtained by his friend Mr. Bond, in whose collection it is still preserved. This was in all probability the same bird which had been observed the previous day sporting with a number of the Common Swifts over the reservoir at Kingsbury, Middlesex. 


\section{ORDER III.-RASORES.}

\section{Family-TETRAONIDA.}

Capercaillie (Tetrao urogallus). In the autumn of 1855, a cock and hen of this fine species were shot in the woods known as Burnham Beeches. These birds were taken to an Eton stuffer, and were apparently in good condition. It is most unlikely that they were 'visitors from Scandinavia,' and almost equally so that they could have flown from a Scotch wood; and the only way, therefore, in which their appearance can be accounted for is by supposing that they must have escaped from confinement.

Virginian Colin (Ortyx Virginiana). There seems to be no doubt that this species, which is also known as the Virginian Quail or Partridge, has little claim to be considered a British bird. It has frequently been kept in confinement in this country, and the probability is that the few which have been shot here at intervals were birds which had been restored to liberty or regained it by accident. Solitary individuals have been shot in different localities in Berkshire, and in I850 Mr. Hasell received some in the 
flesh, which had been shot in Windsor Great Park. His Royal Highness the late Prince Consort turned out a great number of these Quails in the neighbourhood of Windsor about the year I 840 . Of these many, no doubt, found their way into other counties, and those which were obtained by Mr. Hasell in I 850 were in all probability descendants of this old stock.

\section{Family-STRUTHIONIDA.}

GREAT BUSTARD (Otis tarda). This noble species (now, it is feared, extinct in England*) was, according to the Rev. F. O. Morris, met with on the Lambourne Downs, in Berkshire, up to the year I802, after which date none, so far as I am aware, have occurred in either of the two counties.

LitTle Bustard (Otis tetrax). A very rare visitant to Britain. One was killed in September, 1858 , in Berkshire, but not far from the borders of Oxfordshire, by two of the Fellows of St. John's College, Oxford. For this addition to my list I am indebted to Mr. Dalziel Mackenzie.

* The last Great Bustard recorded to have been observed in Britain was one which was seen by Mr. T. A. Rising, near Horsey, in Norfolk, while he was out wild-fowl shooting, upon the 7 th of January, 1867. (See the Field, for Jan. I9, I867.)

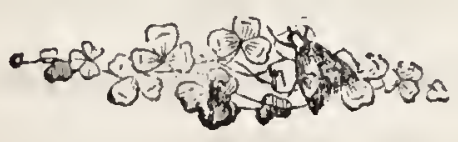




\section{ORDER IV.-GRALLATORES.}

\section{Genus-CALIDRIS.}

SANDERLIng (Calidris arenaria). A visitor in spring and autumn to our coasts, but nowhere a numerous species. It is a bird of pleasing, though plain appearance, and may easily be distinguished from all other Sandpipers by the absence of a hind toe. In this respect, as well as in the shorter bill and rounded head, it resembles the Plovers. It is rarely found far inland, but Mr. George Lillywhite informed me that he shot a Sanderling on the banks of the Thames not far from Surley Hall in the depth of the winter of I 866 . This was probably a straggler blown from the coast by adverse winds.

\section{Family-ChARADRIIDE.}

Oyster-Catcher (Hamatopus ostralegus). The Oyster-catcher, or Sea-pie, although a common species on many parts of the coast, is not often found inland. Individuals have occasionally been killed on the Thames, and one was seen in March, I866, flying 
over the river near Surley. Another was shot a few years since near Windsor, and I am informed that this species has been observed near Reading.

The Oyster-catcher is one of our handsomest shore birds, and it would be difficult to find a more picturesque sight than a flock of these birds feeding on the rocks at low water, their black and white plumage contrasting admirably with their orange bill and pink legs. The note of the Oyster-catcher is loud and shrill, and is repeated quickly as the bird flies; the call-note is said by Mëyer to resemble the words 'quip-quip,' but the exact note musically expressed will be found in Mr. Harting's Birds of Middlesex, p. I59.

\section{Family-ARDEIDE.}

Purple Heron (Ardea purpurea). This Heron, which is a native of Southern Europe and Africa, can only be considered as a rare straggler to Britain.

An immature female of this species was shot near White Waltham, not far from Windsor, early in September, I86I. It was taken by the man who killed it to Mr. Hasell, one of the Windsor birdstuffers, from whom I learnt the particulars of its capture. The Rev. L. Jenyns, in his 'Manual of British Vertebratæ,' states that the Purple Heron has been killed in Berkshire. The food of this bird is in all respects similar to that of its congeners, viz. 
small fish, frogs, and insects. The Purple Heron is very retiring in its habits, preferring thick reed beds and dense swamps. The Rev. F. Morris says that as many as fifty fish have bcen found in the stomach of one bird.

LitTle Bittern (Botaurus minutus). This bird, the smallest representative of the Ardcida in Britain, is a rare summer visitor to this country; but although so irregular in its appearance here, many examples have occurred at various times in different counties. Yarrell records one which was taken in Berkshire, but he has omitted to note either the date or the locality. Another was shot on the Thames, near Monkey Island, ten or twelve years ago, and was brought to Eton for preservation. The Little Bittern has more than once been procured ncar Surley, and many years ago a few were taken in the neighbourhood of Maidenhead. One was killed near Newbury about twenty years since; and Mr. Wolley kindly informed me of a fine specimen which was shot by a person named Brion, on Queen's Eyot, near Windsor, in the summer of 1860 . The Rev. L. Jenyns mentions its appearance on the river near Windsor; it has once occurred in Buckinghamshire, near Uxbridge, on the borders of the county.

There is no reason why this species should not breed here in favourable localities if unmolested, and a young specimen which Yarrell states was obtained on the banks of the river near Windsor in the summer 
of 1826 , was believed to have been bred there. Two reasons are given for this supposition; firstly, from the fact of the situation being favourable from the quantity of reeds; and secondly, from the circumstance of a second bird, in the same state of plumage, being observed about the same spot where the other was killed, for several days, about the same time.

The food of this bird consists of small fish, frogs, lizards, and insects.

In the Field of the 29th of September, I865, there is a notice of a specimen of the Little Bittern, which was shot at Maidenhead by Mr. T. Marshall, in the latter end of August in that year.* A Windsor birdstuffer informed me of some which were procured in Berkshire several years ago, but he had forgotten the dates on which they were brought to him.

I was informed by Mr. Gould that he had a fine Little Bittern brought to him, which was shot by Simon Wilder, a fisherman, forty years ago, on the river Thames, just above Monkey Island. Mr. Ashmead observes, in the Zoologist for July, 1867, that a specimen of this occasional visitor was captured on Mr. Holmes's pond at Wargrave, on the $4^{\text {th }}$ of May. It was a female, and eggs were in process of formation.

BITTERN (Botaums stellaris). Were marsh lands and fens more common, the Bittern would still be a familiar bird; but, alas! the spread of cultivation has

* Mr. James Britten also sent me a notice of this bird. 
operated to the destruction of this handsome species, and to the disappointment of the ornithologist. Many years since the Bittern was not uncommon on the banks of the Thames, but now it is rarely to be seen. One was killed about the ycar I 855 , near Wargrave.

Bitterns have been shot near Maidenhead, and Mr. R. B. Sharpe wrote me word that there is a male specimen in the collection of Mrs. De Vitré, at Formosa, killed in the immediate neighbourhood by John Wig, about six years ago. I am informed by Mr. Dalziel Mackenzie that a fine specimen of the Bittern was shot at Fawley Court, in Buckinghamshire, in January, I864. The Bittern has bred, within the recollection of the Rev. Harpur Crewe, at one of the reservoirs near Tring, but just in the parish of Drayton Beauchamp, Buckinghamshire. He had unfortunately forgotten the precise year. The nest was placed among some reeds on the reservoir, and both nest and eggs were taken by Mr. Williams, of Tring Park, who I believe still has them in his possession. The female bird was killed off the nest, which was a great pity, as the pair would probably have continued to frequent the reservoir the whole year, had they been unmolested. One was procured at Medmenham, during the year $\mathrm{I} 85 \mathrm{I}$, as Mr. D. Mackenzie was good enough to send me word.

Bitterns have been killed near Windsor, and I was informed by the Rev. C. Wolley that two specimens were obtained some years ago in a field near New- 
bury, Berkshire. The Rev. Bryant Burgess, of Latimer, near Chesham, sent me word that specimens had been taken in that neighbourhood.

The last occurrence of the Bittern in these counties was in the early part of December, I 867, when a fine male was shot by John Wig, near Cookham. It is now in the possession of Mr. Robert Hill, who first saw the bird, and endeavoured, though unsuccessfully, to obtain it.

Night Heron (Nycticorax Gardcni). This rare British Heron is not uncommon in various parts of Europe, but the notices of its occurrence here are 'few and far between.' I have included it in the present list on the authority of Colonel Montagu, who says that Dr. Latham assured him that he had received an account from the late Mr. Pennant of a young Heron of this species which was shot in the vicinity of Cliefden, Buckinghamshire, in 1797.

Colonel Montagu observes that this specimen 'exactly answers to the Gardenian Heron in the 'Planches Enluminées,' No. 939: the whole colour of the plumage dusky, the feathers mostly streaked with white.'

Yarrell says, as also does the Rev. L. Jenyns, that the Night Heron has been killed in Buckinghamshire, but as neither of them give any particulars, they probably refer to Colonel Montagu's bird.

White Stork (Ciconia alba). The Rev. F. O. Morris states, on the authority of Mr. James Dalton, 
of Worcester College, Oxford, that a White Stork was shot a few miles from Buckingham, in the month of September, i 846 .

'The White Stork, from its familiarity, and the services which it renders to man in some countrics by the destruction of reptiles and the removal of offal, has ever secured for itself an especial protection, and an exemption from the persecution which is the lot of the less favoured of the feathered tribes. Its periodical return to its accustomed summer quarters, to its nests, the home of many generations, has ever been regarded with feelings of pleasure, and its visits to the habitations of man have not only been permitted, but sanctioned with welcome. In various parts of Holland the nest of this bird, built on the chimney-top, remains undisturbed for many succeeding years, and the owners constantly return with unerring sagacity to the well-known spot. The joy which they manifest on again taking possession of their deserted dwelling, and the attachment which they testify towards their benevolent hosts, are familiar in the mouths of everyone.'

Glossy Ibis (Ibis falcinellus). The Rev. L. Jenyns says that this beautiful and rare visitor to our shores has been killed in the counties of Cornwall, Devon, Kent, Berks, Norfolk, and Northumberland, as well as in Anglesea and Ireland.

Colonel Montagu was the first ornithologist who pointed out the identity of the supposed varieties of 
this bird (under the names of Glossy, Green, and Bay), and at p. I8I of the last edition* of his Ornithological Dictionary, he records a solitary instance of its occurrence in Berkshire. He says that a Glossy Ibis, which was in the possession of $\mathrm{Mr}$. Lamb, was shot in the month of September, I793, while skimming over the river Thames between Henley and Reading. This bird was in the company of another, but whether that was killed or not I am unaware.

The Ibis lives on the shores of lakes or rivers, and for the most part subsists on fish and insects.

\section{Family-SCOLOPACIDE.}

Common ReDshank (Totanus calidris). The Redshank is an uncertain visitant to these counties, but it is occasionally met with in the spring and autumn. In I 854 several were shot near Wraysbury, and I have seen others which were said to have been procured on the banks of the Thames in the neighbourhood of Windsor and Surley. The Redshank's food consists of marine worms and aquatic insects, and it is an interesting sight to see one of these birds probing for its food with its long bill. It is an expert swimmer, and sometimes perches upon trees.

WoOd SANDPIPER (Totames glareola). An uncommon visitant, generally appearing in spring and

* Vide Mr. Edward Newman's Edition : Van Voorst. 
autumn. A Wood Sandpiper was shot on Dorncy Common, near Eton, a few years since; and the species has been observed on the banks of the Thames, where, however, it is far rarer than its congener the Green Sandpiper. In the spring of 1867 a Wood Sandpiper was killed near Surley, and I examined it shortly afterwards. The man who shot it was ignorant of the species, calling it a Godwit.

Black-Winged STILT (Himantopus melanopterus). The Black-Winged Stilt, or Long-Legged Plover, is a rare visitor indeed to the British Isles. In the spring of 1834 , a bird which so exactly answered to the description of this species that it could be none other, laid two eggs by the side of a large pond in a wood near Beaconsfield, and was captured in a net while sitting upon them. Nobody knew at the time what this bird was, but a person who saw it told me it had exceedingly long legs, and was like a Plover in the shape of its body, which was black and white; it was kept alive for some days, being fed upon small fish, but it eventually died, and was stuffed in Eton. Both the eggs were sold, and I believe the bird was also disposed of, but I have never been able either to obtain a view of it or learn any further particulars.

BAR-TAILED Godwit (Limosa mefa). Although at some seasons of the year this species is not uncommon on marsh land near the sea, it is rarcly found far inland, and never remains to breed in England. 
For a notice of the only occurrence of the Bartailed Godwit in Buckinghamshire with which I am acquainted, I am indebted to the Rev. Bryant Burgess, of Latimer, who kindly wrote me word that in the first week of May, I 846, a pair of these birds were observed to frequent a field on the farm of Mr. Biggs, in the parish of Slapton. The hen bird was shot by Mr. Biggs, but unfortunately he neglected to skin it, and it became putrid. When in this state it was examined by Mr. Burgess, who found it to be in an intermediate state of plumage, having nearly acquired the red breast which is peculiar to this species in summer. Both birds were very tame, and suffered a near approach without manifesting any alarm. Unfortunately, this fearlessness proved fatal to one of them.

RUFF-female ReEve-(Machetes pugnax). 'The trade of catching Ruffs,' says Montagu,* ' is confined to a very few persons, which, at present, scarcely repays their trouble and expense of nets. These people live in obscure places on the verge of the fens, and are found out with difficulty, for few, if any birds are ever bought, but by those who make a trade of fattening them for table; and they sedulously conceal the abode of the fowlers, so much that by no art could we obtain from any where they resided; and in order to deceive us, after evading our entreaties, gave us instructions that led us in quite a contrary direction. The reason of all

* 'Dictionary of British Birds,' p. 275. 
this was obvious, for after much labour and search, in the most obscure places, we found out a very civil and intelligent fowler, who resided close to Spalding, at Fen-gate, by name William Burton; and, strange to say, that although this man had constantly sold Ruffs to Mr. Towns, a noted feeder, as also to another feeder at Cowbit, neither of these persons could be induced to inform us even of the name of this fowler.'

The Ruff is a rare bird in both counties; I am not aware of more than two instances of its occurrence. A Reeve was shot in the neighbourhood of Chesham several years ago, and is now in the collection of Mr. Burgess at Latimer. A few winters ago, as I am informed by Mr. Sharpe, a second Reeve was killed near Cookham, and was preserved by $\mathrm{Mr}$. Briggs of that place.

GREat SNipe (Scolopax major). Pennant was the first to add this species to the British fauna, but since his time many examples have been recorded as killed in various parts of the country. This bird is also known by the less appropriate name of 'Solitary Snipe,' since it is as often found in pairs as singly.

'The Great Snipe resembles the Jack Snipe very much in its habits, lying close, and when disturbed rarely flying far. It begins to breed early in May. The nest is similar to, and placed in the same position as, that of the common species. The eggs are four in number. These are of a ycllow olive- 
brown, spotted with two shades of reddish-brown; the length one inch nine lines, by one inch and two lines in breadth.' $*$

My friend Mr. Sharpe told me of a Great Snipe (now in the collection of Mrs. De Vitré at Formosa), which was shot by Mr. John Wig, a few winters ago, in the immediate neighbourhood of Cookham.

BROWn SNIPE (Macrorhampluzs griseus). I have reason to believe that one specimen of this rare Snipe has been procured in the county of Buckingham, but the details which have come to hand are very scanty. My friend Mr. Way informs me that a few years ago a relative of his shot a very rare Snipe, which is now preserved in the possession of this relative. He described the specimen to me as a 'Yellow Snipe,' and from his statement I conclude it to have been an example of Macrorhamphus griseus. Not having seen the bird, however, I am guided only by the description.

Knot (Tringa Canutus). + This bird is an uncommon visitor so far inland, although, like many others of the shore birds, it is plentiful on most parts of the coast in spring and autumn. Mr. R. B. Sharpe informed me that a single Knot was shot during the winter of I 865 near Cookham, and was taken to Mr. Joseph Ford, of that place, for preservation.

* Yarrell's 'British Birds,' vol. iii. p. 22.

+ This bird has received its name, Canutus, from the fact that it was formerly 'a dainty dish to set before the ling' Canute: hence Canute-Kanute-Knout-Knot. 
Family--RALLID A:

Baillon's CRAKE (Crex Baillonii). This bird, which was named after M. Baillon, who found it in the marshes of Picardy, is of rare occurrence in Britain. A single specimen was shot near the town of Newbury, in Berkshire, several years ago, but I have been unfortunately unable to gain any further information respecting it.

Carolina Crake (Crex Carolina). The following note in the Zoologist for April, I865, was communicated by Mr. H. S. Eyre, of Newington, near Sittingbourne.

'In October last, I864, I shot, on the banks of the Kennet, near Newbury, a Carolina Crake (Porzana Carolina). It was exhibited by Mr. A. Newton, of Magdalene College, Cambridge, at the meeting of the Zoological Society on the itth of February, who remarked on the fact of the species being met with so far from its usual range as Grecnland, and also on some vagrant habits of some other Rallidx; for instance, the common English Corn Crakc, which has not only occurred once in Greenland, but also in the Bermudas, and several times on the eastern coast of the United States.' Mr. Eyre sent me notice of this capture, and it appears that there is no doubt as to the species, the bird having been examined by Mr. Gould, Professor Newton, and others. Henceforth, 
therefore, the Carolina Crake must rank in the already long list of rare and accidental stragglers to Great Britain.

\section{Fannily-LOBIPEDIDÆ.}

Grey Phalarope (Phalaropus lobatus). This little Lobe-foot, which has been aptly compared to a miniature Teal, makes its appearance on the British coast almost every year, when journeying southwards on its autumnal migration. In the time of Pennant it was hardly known, but of late years it has occurred much more frequently. In the autumn of I 866 there was an extraordinarily large immigration of these birds, no less than 250 specimens having been taken in Sussex, 86 in Hampshire, and 64 in Devonshire, besides many others in various counties. Mr. J. H. Gurney, jun. has published an interesting pamphlet in which he enumerates the localities visited in that year by this species, and, so far as could be ascertained, the number of captures, with the particulars of each.*

One was killed at Shinfield, Berkshire, in March, I794, as recorded by the Rev. F. O. Morris. The Rev. Charles Wolley informs me that, in December, I85I, a Grey Phalarope was shot on the Thames while disporting itself under the Great Western

* "A Summary of the Occurrences of the Grey Phalarope in Great Britain in I866." London : John Van Voorst, Paternoster Row. 
Railway Bridge, Windsor, by a man named Hall, who preserved it. Out of the flocks which visited England in the autumn of 1866 , a single specimen only seems to have occurred in Buckinghamshire. This bird was seen on the canal at Halton. On the Igth of September; I866, Mr. Gurney states that a Grey Phalarope was shot by a fisherman on an eyot of the Thames between Pangbourne in Berkshire, and Whitchurch in Oxfordshire. Its beak was full of small flies and gnats. Miss Flockton, the possessor of this specimen, told Mr. Gurney that it was an old female bird, in that state of plumage intermediate between the winter and summer dress.

Mr. Gould identified a bird as a Grey Phalarope which had been observed by a man named Henry Wilder on the river near Maidenhead, in the autumn of 1867 . It was swimming on the water, and he struck at it with his oar, but the bird, although much exhausted, managed to escape.

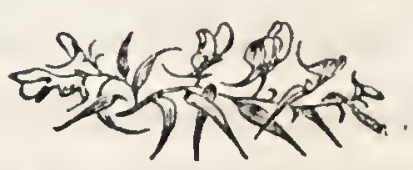


ORDER V.-NATATORES.

Family-ANATID $Æ$.

GREY-LAG GoOSE (Anser ferus). A rare winter visitor, only occurring in the severest weather. $\mathrm{My}$ friend Mr. Crewe informs me that a few Grey-lag Geese generally frequent the low inundated meadows at the commencement of the Vale of Aylesbury, in the parishes of Hulcott and Aston-Clinton, during the winter months. Mr. Sharpe states that this bird has been obtained near Cookham; and Mr. L. Hall, of Windsor, once shot a goose of this species, out of a flock of seven, near Boveney Lock.

WhITE-Fronted Goose (Anser albifrons). A rare winter visitant here, although it appears in some numbers on our coasts in cold weather.

It has occasionally been seen and shot on the Thames. Early in 1867 one was seen flying over the river by a friend near Surley, and several others of the same species were observed in that neighbourhood about the same time. The White-fronted Goose has occasionally occurred in winter on the reservoirs near Drayton Beauchamp; and, during 
the last ten years, several specimens have been obtained near Eton, Windsor, and Datchet.

Bernicle Goose (Anser leucopsis). A rarer visitor here even than the last-named, although, like it, numerous on the coast in winter. A few years since a Bernicle Goose was shot near Datchet, and is now in the collection of Mr. Ferryman. Individuals of this species have also been killed on the river near Surley.

Concerning Wild Geese, Mr. Dalziel Mackenzie writes me word as follows:- 'There were a good many Geese seen, and a few shot, on the Thames in the winter of I860-6I; a flock of about one hundred were observed for some days between Henley and Medmenham, Bucks; there are a few generally obtained in a severe winter.'

Egyptian Goose (Anser Egyptiacus). Several specimens of this rare Goose have been taken of late years in this country; but although in the majority of cases the birds are supposed to have escaped from confinement on private lakes and ornamental waters, I see no reason for not including it in the present work, as those birds which have come under my notice have shown no signs of ever having been kept in captivity.

The January, I 795, one was shot at Thatcham, in Berkshire, as stated by Mr. Morris. From that date until I 863 I have been unable to find any record of its occurrence here, although doubtless the species 
must have been met with occasionally during the intervening years. In the winter of 1863 one was killed near Datchet, and taken to Mr. Ferryman, in whose possession it still remains. Another was shot in the neighbourhood of Colnbrook during the same year, for a notice of which I am also indebted to Mr. Ferryman. During the cold winter of $1865-66$, a male of this species was killed on the banks of the Thames, near Windsor, by Mr. Thumwood of that town, and was taken for preservation to Mr. Hasell, at whose house I had an opportunity of examining it. The plumage certainly exhibited no marks of recent captivity. Early one cold morning in January, I867, a man named Alfred Brown, of Eton, killed two Egyptian Geese at one shot on Dorney Common; he took them to Eton, where I subsequently had an opportunity of examining them.

SPUR-Winged Goose (Anser gambensis). A single specimen of this rare straggler from Africa is recorded to have been obtained in this country, a full account of which may be found in the third volume of Yarrell's 'British Birds.' I have now the pleasure of recording the capture of a second example of this Goose, and have the additional satisfaction of being able to include it among the birds of Buckinghamshire and Berkshire.

Early one morning in the winter of $1858-59$, as an Eton waterman named John Haverly was walking along the Thames near Boveney Weir, armed with 
an old musket, on the look-out for ducks, he saw a large dark-coloured bird fighting with some Swans in the middle of the river, and apparently being worsted in the encounter. On Haverly's appearance the bird rose, and flew past him towards Windsor, following the bends of the river in its flight. Haverly shot at it, but it flew about six hundred yards before falling, which it eventually did on the Buckinghamshire side of the river, at a spot called Clewer Point. It was not quite dead, and showed so much resistance that it required some considerable strength to despatch it. It was preserved by a man named Drye, in Eton, and on dissecting it the stomach was found to contain some green freshwater weeds, and a piece of brass, together with some small stones and particles of gravel. It is now set up in a glass case, and is still in the possession of Haverly.

When inspecting the bird at his house I noted down the following description:-Bill, dull reddish orange, with horny protuberance at the base of the upper mandible; head, on the crown, blackish brown; neck white, with dark brown streaks and blotches; chin and throat, whitey-brown; eyes black, with a yellow rim; the wings of a lovely dark-green bronze colour, with white feathers here and there, and the upper edges of the wings were pure white; the spur, horn colour, and darker at the base than at the tip; tail, dark bronze, appearing green and bright purple 
when exposed in different lights; under tail coverts, white; legs and toes, brownish yellow. The sex unfortunately was not determined when the bird was dissected, the man who stuffed it considering this unimportant.

Canada Goose (Anser Canadensis). Canada Geese have been so frequently killed in this country without exhibiting any signs of having escaped from confinement, that the species seems fully entitled to a place in the list of British Birds. Its occurrence in the inland counties, as may be supposed, is far less frequent than in those counties which possess a sea-coast, and in Buckinghamshire and Berkshire accordingly it is an extremely rare visitant. A single instance only of its appearance has come under my notice. In this case a solitary individual was shot on the river near Windsor in the summer of 1867 , and was taken to one of the local birdstuffers for preservation. The unusual time of year at which the bird was obtained would lead to the supposition that it must have escaped from some park or ornamental water, but it bore not the slightest trace of having ever been in confinement.

POLISH Swan (Cygnus immutabilis). This bird was first distinguished as a separate species by the late Mr. Yarrell, who pointed out its distinctive characters in the 'Proceedings of the Zoological Society of London' for I838, p. I9.

It is extremely rare in England, and I am glad 
to have the opportunity of recording a new instance of its occurrence in this country, and still more gratified to be enabled to include the species in 'The Birds of Berkshire and Buckinghamshire.' During the winter of I $854-55$, an example of the Polish Swan was shot by Mr. Vidler, of Clewer, on the Thames, near Clewer Mill. He took it for preservation to Mr. Hascll, of Windsor, who found it to be a young male. It is still in Mr. Vidler's possession.

BLACK Sivan (Cygmus atratus). A few centuries ago the Black Swan was not supposed to exist, and doubtless many remember the old line-

'Rara avis in terris, nigroque similima cygno.'

Of late years, however, some half-dozen of these birds have been procured on our coasts, and I saw, a short while ago, a young one which had been killed in Suffolk.

About the year I852, a man who lives out in the woods all day, and usually sleeps under a barn or haystack at night, saw a large dark-coloured bird, which he supposed was a Swan, flying high up in the air over some trees near the little village of Burnham. He told Mr. Gerding's gamekeeper this piece of news, and the two went together to try to get a shot at this curious bird, which eventually they did, and the bird-a veritable Black Swan-fell to the gun of the keeper. 
What became of this rare bird I was unable to ascertain, but I believe the skin was never preserved, and that, after being admired as a 'curiosity' it was recklessly thrown away.

Common Shelldrake (Tadorma vulpanser). For beauty of plumage and rich contrast of colour, scarcely one of our wild fowl excels the Shelldrake; but unfortunately it is a rare visitor to the inland counties, preferring a sandy coast, where it rears its young in the deserted rabbit burrows. Hence the name of Burrow Duck, by which it is frequently designated.

I am informed by the Rev. H. Harpur Crewe that he has several times seen this bird swimming about on the large reservoirs near Drayton Beauchamp, where it is an occasional winter visitant. Some years ago a Shelldrake was shot on the Thames near Cookham, but the precise date I have been unable to ascertain. Mr. Sharpe states that during the winter of I $867-68$ a Shelldrake was seen for several days in the neighbourhood of Cookham.

EIDER DUCK (Somateria mollissima). A rare winter visitant to the southern parts of Great Britain, although not uncommon in the north.

The only occurrence of this species in either county with which I am acquainted, is that mentioned by the Rev. F. O. Morris, at Sunninghill, in Berkshire, during a very severe frost. The principal food of the Eider Duck is crustacea, fish, and various marine 
insects. On the I6th of September, I 867 , I saw a young bird of the ycar, in poor condition, which had just been shot at the Nore, and which was of an almost uniform brown colour, without any appearance of white feathers.

Velvet Scoter (Oidcmia fusca). The Velvet Scoter, or Black Duck, seldom ventures far inland, and is only a winter visitant to our sea-coast.

A single individual was procured near Wargrave, in Berkshire, in January, I795, as is recorded by the Rev. F. O. Morris in his 'British Birds.' Mr. Gould, in his beautifully-coloured work, says: 'During the severe winter of I\$66-67, a splendid old male was killed at Cookham, in Berkshire; and many other instances of its occurrence inland might be cited.' Of this specimen I also received a notice from $\mathrm{Mr}$. Sharpe. The Rev. H. Harpur Crewe tells me that he has on two occasions observed the Velvet Scoter on the large reservoirs near Drayton Beauchamp in cold weather. Mr. Morris, in his 'Game Birds and Wild Fowl,' states that this species has been taken in the county of Berkshire, but he unfortunately gives no dates: possibly this may refer to the one which was taken near Wargrave.

HARLEQUIN DUCK (Fuligula histrionica). This rare species has acquired the sobriquet of Harlequin from the rich and variegated colours of its plumage. 
I am only aware of one instance of its occurrence in these counties, and for this $\mathrm{I}$ am indebted to $\mathrm{Mr}$. Sharpe, who has supplied me with so many interesting notes. The bird in question was shot during the winter of I866-67 on the river near Maidenhead, and was preserved by Mr. Wilmot, the birdstuffer of that town.

SMEw (Mergus albellus). The Smew, or White Nun, is a rare visitor to Berkshire and Buckinghamshire, and when it does occur it is almost invariably during very severe weather. Adult males are very rarely met with, the majority of the stragglers that are shot being immature birds. In the winter of $1850-5 \mathrm{I}$, however, a very fine adult male of this species was killed on the Thames near Boveney Locks by a person named Hall, who afterwards had it stuffed in Windsor. Stragglers have occasionally been shot near Surley Hall, and in the neighbourhood of Maidenhead. In the winter of I 86I-62 a flock of five were seen by Mr. Harpur Crewe at the Wilstone reservoir, where they remained several days.

Mr. Drye told me of a male in fine plumage, which was shot on the river near Monkey Island by Thomas Holeman, of Dorney, who sold it for a sovereign.

It would appear from a statement in Bewick's 'British Birds,' that in Norfolk Smews used to be taken in the spring, as a person named Bonfellow, 
of Stockton, in that county, told him that 'Duck and Mallard are taken from August to June. Teal and Widgeon from October to March; Becks, Smee, Golden-eyes, Arps, Cricks, and Pintails or Sea-pheasants, in March and April. Poker Ducks are scldom taken.' * I have occasionally observed a few mature males and many young females of this species on the poulterers' stalls in the London markets. These probably were received from Holland. Mr. Sharpe informed me of a fine male of this species, which was shot a few years ago on Mr. Palmer's estate, near Reading.

MANDARIN DUCK (Aix galliago). This rare duck has never occurred in a wild state, so far as I am aware, in this country, but I am here cnabled to include it as a rare and occasional straggler.

Mr. Sharpe tells me that a very fine adult male Mandarin Duck, in splendid plumage, was shot by Mr. Briggs near Cookham, in the month of May, i866. It might have been, and doubtless was, an escaped specimen, but it was exceedingly wild, and gave Briggs a chase which lasted nearly a whole day before he managed to shoot it. It is now preserved in Mrs. De Vitré's collection at Formosa.

* Bewick's 'British Birds. 


\section{Family-COLyMBIDÆ.}

RED-NeCKed GRebe (Podiceps mbricollis). One of the rarest of our British Grebes, and only occasionally killed here in severe weather. Its food consists of aquatic insects and small fish, and it has the peculiar habit, like all the Grebes, of swallowing portions of its own feathers. A Red-necked Grebe, which was killed at Burghfield, Berkshire, in May, I792, is noticed by the Rev. F. O. Morris in his 'British Birds.' Another fine specimen, in winter plumage, was shot at Sanderton, near Risborough, upon the Ioth of October, I848.

Yarrell says that, "like the other Grebes, it is an expert diver, and very difficult to obtain when at sea, or in other extensive waters where there is ample space to exercise its powers. The nest is described as placed among aquatic herbage and reeds, being built of similar decayed materials. An egg which I obtained from Hamburgh is of a dull white colour tinged with green, two inches in length, by one inch and four lines in breadth.'

The contents of the crop of an immature bird of this species, which I examined on the 28th of December, 1867, and which had been sent from Holland to Leadenhall Market, was a mass of green and rank herbage, and there was no trace of its more usual food -small fish and insects. 
EARED GREBE (Podiceps auritus). The rarest of the five species of Grebes found in Great Britain. It is an inhabitant of the northern and eastern parts of Europe, and has been found breeding so far south as Algeria. It resembles the Sclavonian Grebe in its habits, and lays three or four eggs of a dull yellowish or greenish white, one inch and nine lines in length, and one inch three lines in breadth. The Eared Grebe has occasionally visited the extensive reservoirs in the neighbourhood of Drayton Beauchamp, and has been known to nest there, Mr. Williams, of Tring Park, having taken the nest and eggs a few years since. It generally visits these pieces of water during the early spring months. In the winter of $\mathbf{1} 86 \mathrm{r}$ a man named Allen shot an Eared Grebe as it was swimming on the Thames opposite Boveney Locks.

Great Northern Diver (Colymbus glacialis). The Rev. F. O. Morris observes that some of these fine Divers were killed near Pangbourne and Maidenhead, both in Berkshire, in 1794, but he has omitted to note the season of the year. In the year I 8 Io, one was shot near Newbury, as recorded in Morris's 'British Birds.'

A young one was discovered at Chequers Court, near Risborough, Bucks, upon the 9th of May, 1850. Upon writing for further particulars to Lady Frankland Russell, she very kindly supplied the following note:- The occurrence of the Northern 
Diver at Chequers was quite accidental: it was supposed to be tired and fell into a deep ditch near the house, from whence it was unable to rise again. Its "screams" alarmed a boy who happened to be passing at the time, and he ran to one of the gamekeepers, Chator by name, and the latter found out what the bird was.' It was taken to the house, and Lady Russell determined to send it the Zoological Gardens, but owing to the railway porters refusing to supply Chator with any water for the bird, it died soon after its arrival at the Gardens, and the Society returned it to Lady Russell, who thereupon caused it to be stuffed. An immature Northern Diver was taken in December, I84I, on one of the reservoirs near Drayton Beauchamp. A Great Northern Diver was killed at Virginia Water, near Windsor, on the 4th of February, I85I. This was an exceedingly fine specimen, and was presented to the collection at Eton College by the late Prince Consort. It was preserved by Mr. A. D. Bartlet, and exhibited in the Exhibition of $185 \mathrm{I}$. In November or December, 1859, another was procured at Chesham, as I have been informed by the Rev. Bryant Burgess.

Family-AlCADÆ.

GuILlemot (Uria troile). Rarely met with inland, although a very common bird on many parts of the 
coast. A male bird of this species was caught in the river at Fenny Stratford, on the I 3 th of November, I 852 , during the great floods which then prevailed,* and another was seen near Simpson, in Buckinghamshire, upon the 14th of November, I 852.

Few eggs of British Birds vary more than those of the Guillemot; in an extensive series of many dozens perhaps scarcely two will be found alike.

LitTle AUK (Morgulus melanoloucos-FLeming). A scarce winter visitant to our shores, occasionally driven inland by high winds. The Rev. Bryant Burgess, of Latimer, near Chesham, informed me that a single specimen was taken on one of the large pieces of water in the vicinity of Drayton Bcauchamp, in December, i84I. According to the Rev. F. O. Morris, this bird has also occurred near Newbury, in Berkshire. It is a truly oceanic bird, preferring deep water, and seldom approaching the shore except for the purpose of nidification, or when driven by high winds from its native element.

PUfFin (Fratcrcula arctica). So far as I am aware, this remarkable-looking bird has only once been obtained in Berkshire. Like the last-named species, it is seldom seen inland, and then only in stormy weather.

The Rev. F. O. Morris states that a Puffin was taken alive upon the I6th of March, I8I6, in Northbrooke Street, Newbury. It had probably been 
driven from the coast by storms, and had fallen in the street from exhaustion.

GREAT AUK (Alca impennis). The following extract, referring to the appearance of the Great Auk in Buckinghamshire, must be accepted cum grano salis. It is copied verbatim from the third volume of Yarrell's 'British Birds,' but it is solely in deference to the high authority of that naturalist that it is reprinted in the present work:-

'Mr. Bullock told Dr. Fleming some years ago that a specimen was taken in a pond of fresh water two miles from the Thames, on the estate of Sir William Clayton, near Marlow, in Buckinghamshire.'

That a bird of such thoroughly oceanic habits, and with wings so rudimentary as to be useless for flight, should be found so far inland as stated, seems, if not physically impossible, at all events highly improbable. I have no doubt that the species was misnamed, and that the bird really captured was, in all probability, one of the Divers-either the Great Northern or the Black-throated Diver. I need hardly add that all endeavours to trace a 'Great Auk,' or to gain any further particulars respecting it, have proved utterly unsuccessful. 
Family-PELECANIDA.

Cormorant (Phalacrocorax Carbo). An extremely rare visitor so far inland, although numerous enough on many of our rocky coasts. An example was taken on Frilham Pond, near Newbury, in November, I S03, as recorded in Morris's 'British Birds.' Mr. John Wig shot a good specimen of the Cormorant about the year I 857, near Marlow Railway Bridge, as I have been informed by my friend Mr. Sharpe. It gave no little trouble before it was secured, and showed considerable expertness in diving. It was placed in the collection of Lord Boston, at Hedsor, but this collection has since become dispersed. In 1858 a solitary Cormorant was shot on the large sheet of water at Weston Turville, in Buckinghamshire. It is now stuffed and in the possession of Mr. T. Billington, by whom it was killed.

ShaG (Phalacrocorax graculus). Like the lastnamed, a rare and accidental visitant, seldom flying far from the sea.

The Rev. F. O. Morris states that a Shag was procured near Pangbourne, in Berkshire, in September, 1794. A good female specimen of this bird was shot on the Thames, near Wraysbury, by Mr. Saunders, of Staines, in 1850, and came into the hands of Mr. Hasell for preservation. Those who take an interest in the habits, food, and variations of plumage in this species will be well repaid by referring to the 
June number of the Zoologist for I866, in which is a capital paper on the subject by Mr. Blake-Knox, of Dalkey, co. Dublin.

Colonel Montagu, writing in June, I8I3, says:-'We have been assured that the Shag was shot as far inland as Newbury, in Berkshire: a very rare cccurrence for it to desert salt water, but probably enticed so far by that noble river the Thames, into which the Kennet flows.'

Gannet (Sula alba). The Gannet, or Solan Goose, like the two last-mentioned species, is numerous on the coast, but rarely met with far from the sea. As the time for nidification approaches, great numbers congregate on the celebrated Bass Rock, Lundy Island, the Isle of Ailsa, St. Kilda, and other favourite resorts of sea-birds. Several naturalists, and amongst others Montagu and Bishop Stanley, have maintained that the bird in question has no nostrils. This, however, is not the case, as the Gannet has exceedingly narrow nostrils, well-concealed, and situated at the base of the bill. Its occurrence has been reported near Eton, but on somewhat slender evidence. Mr. Morris says that a young male was shot near Wytham, in Berkshire, the seat of Lord Abingdon. It was killed by his Lordship's gamekeeper upon the I4th of October, I838. Another was seen at the same time; and a third, probably of the same flock, was observed at Weston-on-the-Green, in Oxfordshire, shortly afterwards. The Rev. Bryant Burgess, of Latimer, near 
Chesham, wrote me word that a Gannet was taken by the Rev. T. Rogers, at Sherington, near Newport Pagnell, in November, I847. By a skilful manœuvre he succeeding in securing it, notwithstanding the desperate resistance which it made with its powerful wings and formidable bill. It was kept alive some time by its captor, and fed entirely upon fish.

\section{Family-LARIDE.}

Masked GULI, (Larus capistratus). Temminck first distinguished this species from the Black-headed Gull (Larus ridibundus); it is an extremely rare bird in this country, being found principally in Baffin's Bay and Davis's Straits, and only occasionally wandering to Europe.

The 'History of British Birds' by the Rev. F. O. Morris, contains the only instance which has come under my notice of the occurrence of this bird in the two counties. This notice is very brief: 'In Berkshire, one in immature plumage was obtained near Newbury.' This species has been known to breed at Westra, in the Orkneys.

Pomarine Skua (Lestris pomarimes). By no means a common bird on the coast, and still more rare inland. I was informed by Mr. Gardner, of Oxford Street, that a Skua of this species was sent to them for preservation by a gentleman resident in 
Buckinghamshire, on whose estate it was procured. The precise date, or further particulars, I was unable to ascertain. A second was taken some years since near Crendon; and Mr. Burgess told me of a third which was shot at Chesham, in November or December, I859. This last is in the collection of Mr. Lowndes.

Forked-TAILED Petrel (Thalassidroma Leachii). After a strong gale of wind in the summer of 1847 or 1848 , a man named William Hibbs noticed a bird fluttering against a lamp at the corner of Brocas Lane, Eton; he caught it, and it proved to be a Petrel of this species. He took it to a local birdstuffer, who placed it in a hamper for the night. It appeared extremely thin, and was very weak, although in good plumage. It was killed on the morning after its capture, and was preserved for a gentleman by whom it had been purchased. The Rev. Bryant Burgess, of Latimer Rectory, near Chesham, sent me an account of one of these rare Petrels which was taken in that neighbourhood. Upon the Ist of November, I 859 , during a very strong gale of wind, causing great disasters-not the least of which was the wreck of the Royal CharterMr. Poulter, gardener to Lord Chesham, found a Forked-tailed Petrel lying upon the ground in the deer-park at Latimer. When he first saw it, it was upon its back, vigorously flapping its wings; it unfortunately died almost as soon as it was picked 
up. It was a male bird. The stomach was empty, the whole frame was very thin and emaciated, and it was much battered about the head, as if it had been pecked at by other birds, or come in contact with boughs of some sort. This bird, which was brought to and examined by $\mathrm{Mr}$. Burgess, is now in the collection of Lord Chesham. Another specimen of this rare straggler was picked up in an exhausted state at Woughton, in Buckinghamshire.

Storm Petrel (Thalassidroma pelagica). This, the last and least of our web-footed birds, appears occasionally on the coast in small flocks, and is sometimes, though rarely, driven inland to some distance by adverse winds. Yarrell says that Mr. Bicheno recorded a specimen which was taken near Newbury, in Berlsshire. A second Storm Petrel, a female, in tolerably good plumage, although thin, was taken to a taxidermist named Hall, who resides in Cambridge Terrace, Windsor, about the year I855. It belonged to Mr. Pidgeon, who killed it while it was flying over the gravel pits at Clewer. For some days previously high winds had prevailed. In a large field in the neighbourhood of Burnham, in Buckinghamshire, a third example was shot and preserved by a man named Hebbs; this was in I 865, and the bird, I am informed, was in very poor condition.

A few days after the memorable wreck of the, Royal Charter which was lost upon the 26th of 
October, I 859 , a bird of this species was picked up by some boys, who found it lying dead, but still warm, upon the road opposite the Priory, Burnham. It was presented to Mr. J. Howard of that village, who had it stuffed at Eton, and at whose house I saw it. The Rev. F. O. Morris states, in his 'British Birds,' that Mr. James Dalton, of Worcester College, Oxford, sent him a note of a Storm Petrel which was found dead on the ground not far from the town of Buckingham. In this, as in other instances, he unfortunately gives no date, a practice too common with many authors, and one which is much to be reprehended; for in determining the migratory habits of a species, and its geographical distribution, the exact date at which it makes its appearance in any given locality is of much importance.

I am indebted to Mr. James Britten, the Hon. Secretary to the Natural History Society of High Wycombe, for a notice of a Storm Petrel which was knocked down in the evening of the 2Ist of January, I 868, in the London Road, near Wycombe. It was taken by its captor to Mr. Britten, and although in good plumage it appeared very weak. It was enveloped in flannel and placed in a basket for the night. The next day it enjoyed a bath of fresh water, to which it was not averse, and it had an ample feast of cod-liver oil and crumbs of bread. On the following Friday it appeared weaker, and sank immediately on being placed in a bath prepared 
with 'Tidman's sea salt.' On the next morning it drank a little oil, and in the evening it flew the length of the drawing-room several times. On the Sunday it could scarcely fly, and on the following Monday it died from exhaustion, having lived in confinement nearly a week.

'(1) all ne fobols of the air, bless ne the apord: 整raise 


\section{INDEX.}

\section{ENGLISH NOMENCLATURE.}

A.

Accentor, Hedge

Alpine Swift .

Arctic Tern

Auk, Great

,, Little

B.

Baillon's Crake . • . . 196

Barn Ozul . . . . . 8

Barred Woodpecker, Lesser . 44

Bar-tailed Godwit . . . I92

Beam bird. . . . . . . 74

Bean Goose • • • . . II7

Bearded Reedling . . . I'74 Tit. . . . . I 74

Bee-eater . . . . . I80

Bernicle Goose . . . . 200

Bittern, Common . . . IS7

, Little . . . . I86

Black Grouse . • . . 56

Black Duck . . . . . . 206

Black Redstart . . . . I7I

Black Swan . . . . . 204

Black Tern • . . . . I49

Black Woodpecker, Great . I 78

Blackbird . . . . . . I4

Black-cap . . . . . 82

Black-cap. . . . . 23, 25

Blackchin . . . . . . 67

Black-hexded Bunting . . . 29

Black-headed Gull . . . . I5I

Black-winged Stilt . . . 192

Blue-cap • . . . . . . 24

Blue Tit . . . . . . 24

Bohemian Waxwing . . . I74

Bottle Tit . . . . . . 25

Bramble Finch . . . . . I06

Brambling . . . . . 106

Brent Goose . . . . . I I

Brown Linnet . . • . . 37

Brown Owol . . . . . 8, 10
Brown Snipe . . . . 195

Bullfinch, Common . . . 37

Bumbarrel ... . . . 25

Bunting, Black-headed . . 29

Cirl . . . . 176

Common . . . 29

Corn . . . . 29

Ortolan . . . I77

Recd . . . . . 29

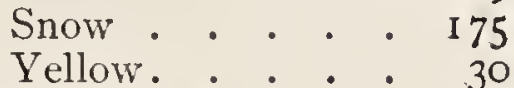

Bustard, Great . . . . 183

, Little •. • . 183

Butcher-bird . . . . . . 72

Buzzard . . . . . . 4

,, Common . . . . 164

" Honey . . . . . 165

", Moor . . . . 4

, Rough-legged . . . 165

C.

Canada Goose . . . . 203

Capercaillie . . . . . $\mathbf{I} 82$

Carolina Crake . . . . . 196

Carrion Crow . . . . 39

Chaffinch • • • . . 3 I

Chatterer, Bohemian . . 174

Chiff-chaff . . . . . 85

Cirl Bunting . . . . . I 76

Cole Tit . . . . . . . 24

Colin, Virginian . . . 182

Common Bittern . . . . I 87

, Bullfinch . • . . 37

" Bunting • . . • 29

," Buzzard • • • • • 164

," Coot . . . . 62

", Creeper . . . . 49

, Crossbill . . . . I II

", Curlew . . . . 142

", Guillemot . . . 2 II

$\therefore$ Gull . . . . . I52

", Heron. . . . 60 
37

,, Partridge. . . . 57

, Pheasant. . . 56

", Quail . . . . I 38

, kedpole . . . I IO

" Kedshank . . . I9 I

", Sandpiper . . . 98

,, Shelldralie . . . 205

", Snipe . . . . II5

,, Starling . . . 33

," Swift . . . . 9 I

, Tern . . . . 147

," Whitethroat . . $\delta_{3}$

Corn Bunting • . • . . 29

Coot, Buld . . • . . 72

Cormorant, Common . . 213

Concrake • • • • . . 99

Crake, Baillon's • • . . 196

,, Carolina . . . . 196

,, Spotted . . . . 99

Creeper, Common . • . . 49

Crossbill, Common . . . . I I I

Crow, Carrion . . . . 39

,, Hooded . . . . . II2

,, Royston. . . . II2

Cuckoo, Common . . . . 87

Curlew, Common . . . 142

, Stone

Cushat Dove.
TAGiE

Duck, Scaup. . . . . 129

, Tufted . . . . . I 29

,, Velvet . . . . . 206

" Wild . . . . . I 22

Dun-diver . . . . . . I3I

Dunlin • • . • . . 145

Dunnock . . . . . . . It

Dusiry Grebe . . . . . I 32

I.

Eagle, Fishing . . . . I5

„, Golden . . . I 54

,, White-tailed . . . 155

Eared Grebe . . . . . 209

Egyptian Goose. • . . 200

Eider Duck . . . . . 205

F.

Fallow-chat . . . . . 76

Felt, Felifare, Fieldfare . . 105

Finch, Bramble . . . . 106

, Mountain . . . 106

Fire-crested Regulus . • . 173

Wren . . . 173

Flycatcher, Pied : . . 169

Spotted . . 74

Forked-tailed Petrel . . . 2 I7

G.

Gadwall Duck . . . . I2I

Gallinule, Common . . . 62

Gannet . • • • . 215

Garden Warbler. • . . 82

Gargeney Duck . . . . . I23

Glossy Ibis . . . . . I9O

Godwit, Bar-tailed . . . . 192

Golden Eagle . . . . 154

, Oriole . . . . I70

, Plover . . . . . I14

Golden-crested Regulus . . 23

,, Wren . . 23

Golden-eye Duck . . . I29

Goldfinch . . . . . . 36

Goosander • . . . . I I3I

Goose, Bean . . . . I I 7

, Bernicle . . . 200

, Brent . . . . II 


\begin{tabular}{|c|c|c|}
\hline & & \\
\hline Goose & , Canada. . . & . 203 \\
\hline , , & Egyptian . . & . 200 \\
\hline ," & Gray-lag & . 199 \\
\hline , & Solan & . 215 \\
\hline , & Spur-winged & . $20 \mathrm{I}$ \\
\hline ," & White-fronted . & . 199 \\
\hline & Wild. & - $\quad 199$ \\
\hline Grassh & nopper Warbler . & 78 \\
\hline Great & Auk . . & 213 \\
\hline ," & Black Woodpecker. & 178 \\
\hline, & Bustard & 183 \\
\hline, & Crested Grebe . & 65 \\
\hline & Grey Shrike . & 168 \\
\hline , & Northern Diver. & 210 \\
\hline ,, & Plover & 97 \\
\hline & Snipe & I94 \\
\hline & Spotted Wo & 44. \\
\hline & & \\
\hline
\end{tabular}

Grebe, Blackchin . . . . 67

" Dussky . . . . . $\mathrm{I}_{32}$

," Eared . . . . 209

,, Great Crested . . . 65

,, Horned . . . . . 132

,, Little. . . . . . 67

, Red-necked. . . . 209

"Sclavonian . . . . 132

," Silver . . . . I34

Greenfinch . . . . . 34

Green Plover. . . . . 59

,, Sandpiper . . . . I43

Green Woodpecker . . . 43

Greenshank . . . . . . I 45

Grey Phalarope . . . . 197

" Shrike . . . . . I68

"Wagtail . . . . . 26

Grey-lag Goose . . . . . . 199

Grosbeak . . . . . 35

Grouse, Black . . . . ${ }_{56}^{6}$

, Wood . . . . 182

Guillemot, Common . . . 2 II

Gull, Black-headed . . . . $15 \mathbf{I}$

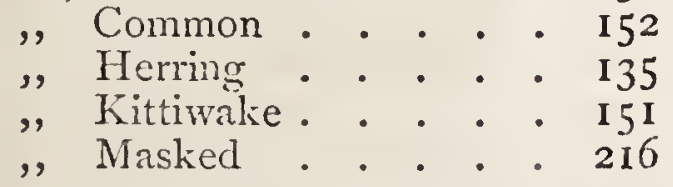

H.

Harlequin Duck . . . . 206 Harrier, Hen . . . . . 4 ," Harsh : . . . : 4
PAGE

Hawnechon 166

Hawfinch . . . . . 35

Hawk, Fishing . . . . 158

Hedge Accentor . . . . I I

," Sparroze . . . . I7

" Warbler . . . . 17

Hen Harrier . . . . • 4

Heron, Common . . . . 60

" Moll. . . . . . 60

,, Molley . . . . 60

, Night . . . . . 189

", Purple . . . . 185

Herring Gull . • • • • • 135

Hobby : : : $\cdot 43,44$

Honey Buzzard . . . . 165

Hooded Crow . . . . II

Hooper . . . . . . II 8

Ifoopoe • • . . . . . I 179

Horned Grebe . . . . I32

House Sparrow . . . . 33

I, J.

Ibis, Glossy . . . . . . 190

Jackdaw . . . . . 40

Jack Snipe . . . . . . II6

Jay . . . . . . . 42

K.

Kestrel. . . . . . . I

Kingfisher. . . . . . 52

Kinglet . . . . . . . 23

Kite . . . . . 163

Kittiwake. . . . . . $15 \mathrm{I}$

Knot . . . . . 195

L.

Landrail . . . . . . 99

Lapwing . . . . . . . 59

Lark, Sky. • . . . . 27

Wood . . . . 29

Leach's Petrel : . . . $\quad 217$

Lesser Redpole . . . . I IO

, Spotted Woodpecker . 44

", Tern . . . . . 49

", Whitethroat . . . 83

Linnet, Bromen . . . . . 37

" Common . . . . 37

" Grey. . . . . 37 
Limnet, Mountain . . . I I I I " Redbreasted . • . 37

Rose . . . . . 37

Little Auk . . • • . . 212

, Bittern. . • • IS6

" Black and White Woodpecker . . . . 44

, Bustard . . . . I83

, Grebe . . . . . 67

, Sea Suallow . . . 149

Long-eared Owl • • . 5

Long-legged Plover. . . . 192

Long-tailed Tit . . . . 25

M.

P.

Magpie • . . . . . 42

Mallard . • . • • • . 122

Mandarin Duck . . . . 208

Marsh Harrier • • • • . 4

Marsh Tit. . . . . . . 25

Martin, Common . . . 90

90

, Sand . . . . . 93

Masked Gull . . . • 2 I6

Meadow Pipit . . . . 27

Merganser, Red-breasted . . I3I

Merlin . • . . . . 102

Missel Thrush . . . . . 12

Montagu's Harrier . . . 166

Moor Buzzard • • . • . 4

Moor-hen . . . . . 62

Mountain Finch . . . . 106

,, Linnet • . • . I I I

Mute Swarrow . • • 32

32
64

N.

Nettle-crecper. . . . . . 83

Night Heron . • • • • $\quad$ I 89

Nightingale . . . . . $\delta_{\mathbf{I}}$

Nightjar • • • • • • 92

Norfolk Plover . • . . . 97

Northern Diver, Great . . 210

Nuthatch . . . . 50

O.

Orange-legged Hobby . . . I62

Oriole, Golden . . . . I70

Ortolan Bunting . . . . 177

Osprey • . . • . . 158

Ousel, Ring . . . . . . 136

Owl, Barn . . • . . 8

,, Brown . . . . . 5, 10

, Horned. • . . . 5

,, Long-eared . . . . 5

, Short-eared . . . . I04

,, Scops-eared . . . I66

,, Tawny . • • • • . IO

, Tengmalm's . . . 167

"White . . . . . 8

Oyster-catcher . . . . $\mathrm{r}_{4}$

Partridge, Common . . 57

, Red-legged . . . 57

," Virginian • • 182

Pastor, Rose-coloured . . 177

Peewit . • • . . . 59

Peregrine Falcon . . . 162

Petrel, Forked-tailed . . . 2 I7

, Leach's . . . . 217

, Storm . . . . 218

Phalarope, Grey . • • . 197

Pheasant, Bohcmian . . 56

, Common. . . 56

, Picd . . . . 56

, White' . . . 56

Pied Fly-catcher • . . . I69

"Oyster-catcher. . . I 84

,, Wagtail . . . . . 26

,, Woodpecker. . . . 44

Pigeon, Wood. . . . . 54, 55

Pintail Duck . . . . . 122

Pipit Lark . . . . . . 27

Pipit, Meadow . . . . 27

,, Tree . . . . . 86

Plover, Golden . . . . II4

" Great . . . . 97

" Green . . . . . 59

" Long-legged . . 192

, Norfoll. . . . . 97

, Ringed . . . . . r r I

Pochard Duck . . . . I 27

Polish Swan . . . . . 203

Pomarine Skua . . . . 216

Puffin . . . . . . 212

Purple Heron . . . . 185 
Q.

Quail, Common . , Virginian.

$\mathrm{R}$.

Rail, Land . . . . . . 99

"Water..... 6 $\mathbf{I}$

Raven . . . . . . 39

Ray's Wagtail . . . . . 85

Red-backed Shrike. . . . 72

Redbreast . . . . . . Is

Red-breasted Merganser • . I3I

Red-fuoted Falcon . . . . I62

Red-legged Partridge . . . 5

Red-necked Grebe . . . . 209

Redpole, Common . . . . I Io

" Lesser . . . . . I IO

Redshank, Common . . . I9I

Redstart, Black . . . . I 7 I

") Common. • • . 75

Red-throated Diver . . . I34

Redwing . . . . . . 106

Reed Warbler . . . . 80

Reedling, Bearded . . . . I74

Reeve . . . . . . . 193

Regulus, Fire-crested . • . 173

Ring Ousel . . . . . $\begin{array}{r}23 \\ \text { I } 36\end{array}$

Ringdove . . . . . . 54

Ringed Dotterel . . . I40

Ringed Plover . . . . I4I

Ringtail . . . . . . 4

Robin . . . . . . . 18

Rook . . . . . . . 40

Rose-coloured Ousel . . I 177

,, Pastor . . I 177

" Starling . . 177

Rough-legged Buzzard. . . I65

Royston Crow . . . . . II

Ruff . . . . . . . 193

S.

Sand-Martin . . . . . 90

Sanderling . . . . . I84

Sandpiper, Common . . 98

143

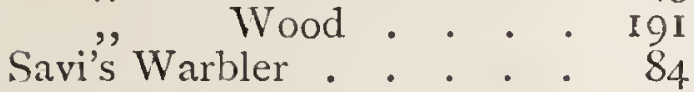

Sazv-billed Dizer . . . . I3I

Scaup Duck . . . . . . I29
PAGR

I 32

Scops-eared Owl . . 106

Scoter, Common . . . . I25

"Velvet . . . 206

Sea-pie. . . . . . 184

Sea Szuallow . . . . . 147

149

149

Sedge Warbler . . . . 75

Shag . . . . . . $2 \mathrm{I}_{4}$

Shelldrake • . . . . 205

Short-eared Owl . . . 104

Shoveler . . . . . . I2 I

Shrike, Great Grey. . . . 168

" Red . • • . 72

Siskin Red-backed • $\cdot 72$

Skua, Pomarine.

Skylark . . . . . . 27

Smew . . . . . 207

Snipe, Brown . . . . 195

,, Common. . . . . II5

" Great. . . . . 194

,, Jack . . . . . II 6

", Sicmmer . . . . 98

Snow Bunting . . . . 175

Solan Goose . . . . . . 215

Song Thrush . . . . . . I I

Sparrow, Hedge . . . . 13

" House. . . . 33

" Mountain . . . 32

" Tree.... 32

Sparrowhawk . . . . 3

Spotted Crake . . . . . 99

,, Flycatcher. . . 74

Spur-winged Goose. . . . 201

Stare . . . . . . 35

Starling, Conmmon . . . 38

Stilt, Black-winged. . . . 192

Stock Dove . . . . . 55

Stonechat . . . . . . 21

Stone Curleze. . . . . . 97

Stork, White. . . . . I89

Stormcock . . . . . $21 \mathrm{IS}$

Storm Petrel . . . . . 218

Summer Snipe . . . 98, 145

Summer Teal. . . . . . I 23

Swallow, Chimney . . . 88

Swallow-tailed Kite . . . 163

Swan, Black . . . . . 204

Swan, Domestic . . . . . $\sigma_{4}$ 
, Hooper

,, Mute.

,, Polish . . . . 203

, lVild. . . . . IIS

Swan-mark, The Eton Col- IIS lege . . . . . . 64

Swift, Alpine. . . . . . IS I

"Common • . . . 9 I

, iVhite-bellied . . ISI

T.

Tawny Owl .

IO

Teal, Common

123

,, Summer

'Tengmalm's Owl

Tern, Arctic

, Black .

, Common

Lesser.

Thick-kneed Plore?

Thrush, Common

,, Missel

Titterel, The

Tit, Bearded.

, Blue

, Cole

,, Great

,, Long-tailed

Marsh

Tit-lark

Tree Pipit.

,, Sparrow

'Tufted Duck

, Pochard.

Turtle Dove.

V.

Velvet Duck .

206

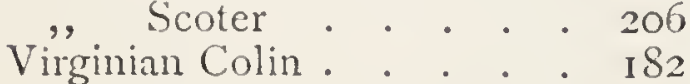

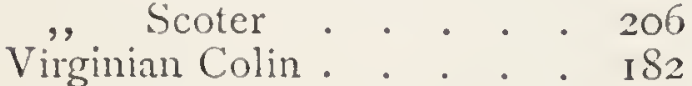

, Partridge. . . . $\quad$ 82

W.

Wagtail, Grey

26

26

85

., Yellow . . . $\quad S_{5}$

llarbler, Dartford . . . 22

, Giarclen . . . $\quad S_{2}$

, Cirasshopper.
Warbler, Hitge .

PAKE

. I 7

, keed . . . . So

, Seckre. . . . $7 S$

, Savi's. . . $S_{4}$

, Wood. . . . $S_{4}$

Water Rail . . . . . 6I

61
170

Waxwing, Bohemian . . I I74

Whaup . . . . . . I42

Wheatear. . . . . 76

Whimbrel . . . . . I43

Whinchat . . . . . . 76

Whistling Swan. . . . . IIS

White-bellied Swift . . . ISI

, Fronted Goose . . . 199

, Owl . . . . S

, Stork . . . . . IS9

,, Tailed Eagle . . . I 55

Whitethroat, Common . . $\quad 83$

, Lesser . . $\quad S_{3}$

Wigeon . . . . . . 124

IVild Duck . . . . . . I 22

, Goose . . . . . . I99

, Sruan . . . . . I I8

Willow Warbler . . . . 84

IVindhower . . . . . . I I

Woodcock . . . . . . II4

Wood Grouse. . . . . . I 82

Wood lark . . . . . . 29

Woodpecker, Barred . . . 44

, Little Barred . 44

,$\quad$ Great Black . 178

, $\quad$ Great Spotted . 44

, Green . . 43

,$\quad$ I.esser Spotted. 44

" l'ied. . . . 44

Woodpic . . . . . . . 44

Wootpigeon, The . . . .54,55

IVood Sandpiper . . . I9I

,, Warbler. . . . 84

," Wren . . . . . 84

Wren, Common . . . . 49

Wryneck . . . . . . 80

Y.

Yaffle . . . . . . . . $4 \mathrm{C}$

Yellow Ammer . . . . . 30

, Bunting . . . . 30

, Hammer . . . 30

,, Wastail . . . . 58

, Varbler. . . . $4 \$$

,, IVien. . . . . 84 
To the following SUBSCRIBERS I beg to return my thanks :-

H.R.H. Prince Arthur (2 copies).

H.R.H. PRince Leopold (I copy).

H.R.H. PRincess Louise (2 copies).

Her Majesty's Library.

Affleck, R. Esq.

Ainger, A. C. Esq.

Albemarle, the Countess of $(4$ copies)

Allen, P. Esq.

Alleyne, E. G. F. Esq.

Alston, E. R. Esq.

Amcotts, T. C. Esq.

Ansell, Miss L.

Arkwright, F. C. Esq.

Arnold, Mrs.

Astley, F. D. Esq.

Atkins, Mr.

Balston, Rev. E., D.D. (2 copies)

Barton, C. M. Esq.

Barnett, P. Esq.

Barwell, Mrs.

Bastard, Mrs. (2 copies)

Bearcroft, E. H. Esq.

Beaumont, P. F. Esq.

Beechcroft, R. T. Esq.
Bell, J. C. Esq.

Bell, Professor Thomas, F.R.S., F.L.S.

Bernard, Lord

Bevan, E. B. L. Esq.

Biddulph, General Sir Thomas

Bingham, Hon. J.

Birch, J. Esq.

Blackburn, F. W. Esq.

Blake, A. M. Esq.

Blake, C. F. Esq.

Blane, G. S. Esq.

Blaxall, Mrs.

Block, C. Esq.

Blood, Mrs.

Bond, W. H. Esq.

Bonsor, A. G. Esq.

Borrough, E. H. Esq.

Bovill, A. G. Esq.

Bowstead, R. M. Esq. M.D.

Bowyer-Smijth, The Dowager Lady 
Bradby, A. S. Esq.

Bramston, Rev. E.

Bramstone, Miss

Branker, W. S. Esq.

Bree, C. R. Esq. M.D.

Brett, R. Esq.

Brown, H. C. Esq.

Brown, J. A. H. Esq.

Brown, Mr. T.

Brown, Mr. WV.

Brown, Mrs.

Browning, O. Esq.

Brownlow, Earl

Buckland, F. Esq., F.R.S.

Budd, T. Esq.

Burgess, Rev. B.

Burnett, H. A. Esq.

Busk, Miss

Butler, Rev. F.

Caldecott, A. Esq.

Campbell, A. Esq.

Campbell, H. Esq.

Cappell, Mrs.

Carden, L. Esq.

Carrington, Hon. R.

Carter, T. J. P. Esq.

Chappel, Mrs. H.

Charlesworth, A. H. Esq.

Charleville, Earl of

Cheney, E. Esq.

Chewton, Viscountess (2 copics)

Childers, E. L. E. Esq.

Churchill, Lord E.

Clark, J. G. Esq. (5 copies)

Clark, Miss

Clerk, G. D. Esq.

Clifton, Lord
Clinton, Lord ( 2 copies)

Clinton, Dowager Lady

Collins, A. Esq.

Collins, H. Esq.

Collins, R. H. Esq. (2 copies)

Combe, H. Esq.

Congreve, C. Esq.

Cordeaux, J. Esq.

Cotton, Hon. C.

- Courthope, A. Esq.

Coventry, C. Esq.

Crake, W. V. Esq.

Crawshay, A. C. Esq.

Crewe, Rev. H. Harpur

Cross, H. Esq.

Cumberbatch, J. C. Esq.

Cust, Colonel F., F.Z.S. (2 copies)

Cust, Colonel the Hon. F. P. (6 copies)

Cust, General the Hon. Sir E.

Cust, Lady

Cust, Captain H. C.

Dalton, H. W. Esq.

Dancer, F. J. Esq.

Darby, A. Esq.

Dawnay, Hon. W. F.

Dawson, J. E. Esq.

Deane, A. E. Esq.

De Grey and Ripon, Earl (3 copies)

De Grey, Hon. J.

De Salis, Count

Dodsworth, Sir C., Bart.

Donken, E. H. Esq.

Downes, W. K. Esq.

Doyne, J. W. Esq. 
Drake, W. T. Esq.

Drinkwater, G. Esq.

Drummond, C. Esq.

Drury, E. C. Esq.

Duckett, C. H. Esq.

Duckworth, Rev. R.

Duncombe, R. Esq.

Durant, C. R. Esq.

Dymes, H. R. Esq.

Edwards, J. Esq. (2 copies)

Ellison, J. Esq. M.D.

Elwes, Captain H., F.Z.S.

Evans, Rev. J. D.

Evans, Rev. Tuckville (3 copies)

Evans, Rev. T. D.

Evans, Mrs.

Evans, Neville, Esq.

Eyre, G. S. Esq.

Ffarrington, J. Esq.

Fawkes, A. Esq.

Fenwick, F. Esq.

Ferguson, H. I. Esq.

Ferrey, Mr.

Finch-Hatton, Hon. M.

Finch-Hatton, Hon. H.

Fleeming, Hon. C.

Fletcher, A. N. Esq.

Floyer, G. W. Esq.

Forbes, Colonel

Formby, J. Esq.

Fothergill, R. Esq.

Garnett, W. Esq.

Garrett, J. H. Esq.

Garth, R. Esq., M.P.

Garth, D. Esq.
Gascoigne, R. F. T. Esq.

Gibbons, J. S. Esq.

Giles, Miss

Gladstone, H. J. Esq.

Gladstone, H. M. Esq.

Gordon, Lord Esmœ

Gordon, J. Esq.

Gould, J. Esq., F.R.S.

Graham, Lord R.

Grant, J. St. John, Esq.

Grimwood, G. G. Esq.

Gunning, R. H. Esq.

Gurney, J. H. Esq.

Hadfield, Captain $\mathrm{H}$.

Hale, Rev. E.

Hale, W. Esq.

Hall, E. Esq.

Hamilton-Gordon, J. Esq.

Hanbury, J. C. Esq.

Harcourt, A. Esq.

Hargreaves, E. Esq.

Harrington, F. Esq.

Harris, J. F. Esq.

Harting, J. E. Esq. F.Z.S.

Hastings, J. F. Esq.

Hawarden, Lord

Hawtrey, Rev. S.

Hayman, Rev. H.

Heathcote, W. E. Esq.

Hele, N. Fenwick Esq. M.D.

Heywood - Jones, R. Esq. (2 copies)

Heywood-Jones, Mrs.

Heywood-Jones, R. Esq.

Hobhouse, H. Esq.

Hodgson, Miss

Hoey, H. B. Esq. 
Holder, C. V. Esq.

Hood, A. A. Esq.

Hope, H. T. Esq.

Howard, H. L. Esq.

Huntsman, F. Esq.

Hussey, Mrs. (4 copies)

Hutchinson, P. Esq.

Hutchinson, Mrs.

Inverurie, Lord

James, A. C. Esq.

Jeffery, W. jun. Esq.

Johnson, E. S. Esq.

Kaye, Lady Caroline Lister.

Kennedy, the late Colonel Clark, C.B.

Kennedy, Mrs. Clark (7 copies)

Keninedy, Lord A.

Kennedy, Arthur Clark, Esq.

King, G. H. Esq. (6 copies)

Kirklinton, C. Esq.

Laing, Mrs. S.

Lawford, L. E. Esq.

Leak, H. W. Esq.

Legge, Hon. H. C.

Legge, J. H. Esq. M.D.

Leward, Mrs.

Leward, Captain

Loder, A. B. Esq.

Loder, W. Esq.

Lucas, E. P. Esq.

Luxford, A. E. Esq.

Mac Call, A. N. L. Esq.

Mac Gregor, J. Esq.
Macnaughton, M. L. Esq.

Maitland, W. Esq.

Mandell, Rev. J. H.

Mangles, C. E. Esq.

Manley, A. F. Esq.

Manners, H. B. Esc.

Marindin, G. E. Esq.

Marshall, W. G. Esq.

Marshall, T. Esq.

Marsham, J. Esq.

Marsham, F. S. Esq.

Mathew, Rev. M. A.

Maude, R. W. Esq.

Maxwell, Mrs. (5 copies)

Milbank, P. Esq.

Milman, W. Esq.

Milner-Gibson, J. M. Esq.

Mitchison, H. S. Esq.

Moore, Rev. Brambley

Moore, Rev. E.

Moore, Lady H.

More, G. Esq.

Morgan, L. G. H. Esq.

Morier, C. Esq.

Murray, G. R. Esq.

Murray, Mrs.

Murray, John, Esq.

Murray, C. Esq.

Musgrave, H. M. Esc.

Naas, Lord

Neal, H. Esq.

Newcome, T. D. Esq.

Newton, Professor Alfred, Esq.

O'Callagan, Hon. C.

Olive, A. J. Esq.

Ottley, Rev. F. 
Otway, W. A. Esq.

Otway, A. J. Esq., M.P.

Pares, E. H. Esq.

Parker, J. Esq.

Parnell, V. A. Esq.

Parry, E. G. Esq.

Partridge, G. H. Esq.

Pepys, Lady Louisa

Peterson, E. P. Esq.

Pigot, Arthur, Esq.

Ponsonby, Hon. E.

Portal, W. W. Esq.

Power, W. H. Esq., M.D.

Preston, H. J. Esq.

Provost of Eton, the Rev. the

Pryor, R. Esq.

Purvis, Arthur, Esq., J.P. (2 copies)

Ranson, J. Esq.

Reade, R. C. Esq.

Reidhaven, Lord

Ricardo, F. C. Esq.

Ricardo, H. Esq.

Rich, Rev. H.

Riddell, J. W. B. Esq.

Riddell, Mrs. J. E. B.

Ridout, A. G. Esq.

Ritchie, R. T. W. Esq.

Roberts, P. Esq.

Roberts, R. W. Esq.

Robertson, Colonel, C.B.

Robinson, H. Esq. C.B.

Rocke, J. Esq.

Roe, Mrs. Henry

Rolle, Hon. M.

Rossmore, Lord,
Runicles, Mr.

Russell, Lady Frankland (2 copies)

Sahl, Herman, Esq.

Schnieder, A. G. Esq.

Schuster, H. L. F. Esq.

Schuster, Mrs. Leo

Scott, Lord Henry

Seaham, Lord

Seebright, E. R. S. Esq.

Sharpe, R. B. Esq.

Sharpe, Mrs.

Shervinton, Major

Skinner, C. L. Esq.

Smith, C. Esq.

Smith, S. H. Esq.

Somers Cocks, R. Esc.

Somerset, Lord E.

Stafford, Marquis of

Stephens, H. P. Esq.

Stevens, Mrs. S.

Stevenson, Henry, Esq., F.L.S.

Stone, Rev. E. D.

Stopford, Lord

Stracey, J. Esq.

Sturgis, J. R. Esq.

Sutton, F. R. Esq.

Sutton, E. G. G. Esq.

Tarver, H. Esq.

Tarver, J. C. Esq.

Taylor, Mr. J.

Thackeray, Rev. F. St. John

Thackeray, Miss

Thornton, A. Esc.

Thorpe, J. W. Esq.

Thorpe, Miss L. 
Todd, A. Esq.

Toler, G. Esq.

Trefusis, Hon. L.

Trollope, R. C. Esq.

Tugwell, A. Esq.

Turner, J. C. Esq.

Turnor, G. H. Esq.

Twopeny, W. Esq. (2 copies)

Vansittart, Mrs. C.

Vere, C. Esq.

Vincent, Rev. T.

Waldegrave, Earl

Waldegrave, Hon. H. W.

Walton, Rev. T. J.

Warner, P. Esq.

Watkins, C. F. Esq.

Way, Rev. H.
Wayte, Rev. W.

Wheeler, T. Esq.

Whitley, Mr.

Whitmore, C. A. Esq.

Wilkinson, E. O. Esq.

Williamson, C. Esq.

Wingate, Major

Wolley, Rev. C.

Wood, C. F. Esq.

Woolward, Rev. A. G.

Wright, J. Esq.

Wright, Richard, Esq.

Wright, J. Esq.

Wright, Robert, Esq.

Yorke, Philip, Esq.

Zoological Socicty of London. 
H|E 


